\title{
INCREASED VASCULAR CONTRACTILITY IN ISOLATED VESSELS FROM CIGARETTE SMOKING RATS IS MEDIATED BY BASAL ENDOTHELIN RELEASE
}

\author{
by \\ MOHAMMAD MAHMUDUR RAHMAN \\ DVM, Bangladesh Agricultural University, 2000 \\ MS, Bangladesh Agricultural University, 2002 \\ A THESIS SUBMITTED IN PARTIAL FULFILLMENT OF \\ THE REQUIREMENTS FOR THE DEGREE OF \\ MASTER OF SCIENCE \\ in \\ THE FACULTY OF GRADUATE STUDIES
}

(Pharmacology and Therapeutics)

THE UNIVERSITY OF BRITISH COLUMBIA

October 2006

(C) Mohammad Mahmudur Rahman, 2006 


\section{ABSTRACT}

The effect of chronic cigarette smoking on endothelin modulation of vascular contraction and CYP enzyme levels was studied in 20 male Sprague-Dawley rats. The animals were divided equally into smoking and non-smoking groups. The smoking group was exposed to 6 research cigarettes per rat per day 5 days a week for 16 weeks. The control group was sham smoked. Functional contractile studies were performed in aortas and carotid arteries to determine the regulation of vascular tone by basal release of endothelin. Liver samples were analyzed for CYP1A1 and CYP1A2 gene expression by RT-PCR. Plasma samples were assessed for endothelin-1 (ET-1) level by enzyme immunoassay (EIA). Treatment of aortas and carotid arteries with bosentan, the dual endothelin receptor antagonist, caused a significant reduction in constrictor responses of smoking rats, indicating increased regulation of tone by endothelin in smoker rats as compared to controls. There was also a greater expression of the cytochrome P450-liver enzymes (CYP1A1 and CYP1A2) in smoker rats. Body weight gain was also significantly decreased in smoker rats. We conclude that increased endothelin release in smoker rats contributes significantly to increased arterial tone and may therefore contribute to the cardiovascular pathophysiology associated with cigarette smoking, such as increased vascular muscularization, increased contraction, decreased dilation and possibly vasospasm. 


\section{TABLE OF CONTENTS}

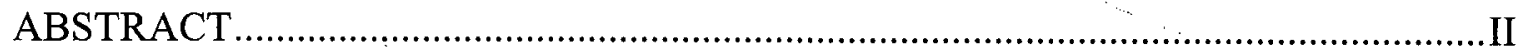

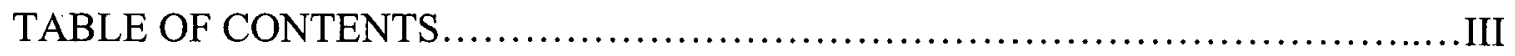

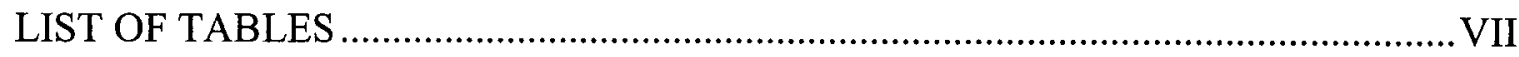

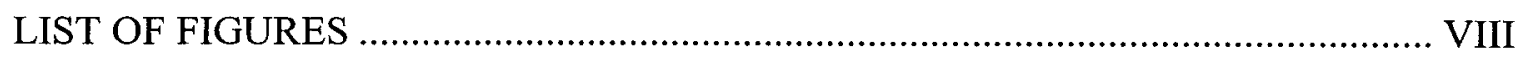

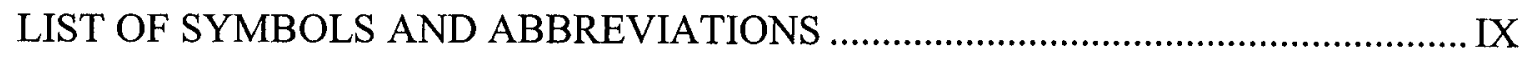

GLOSSARY … -

ACKNOWLEDGEMENTS _................................................................................XXIII

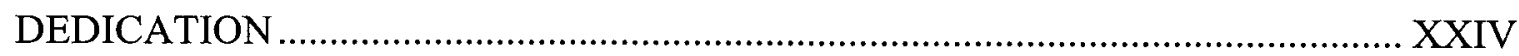

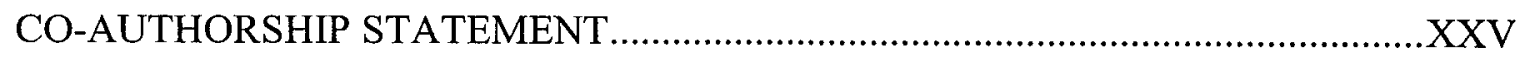

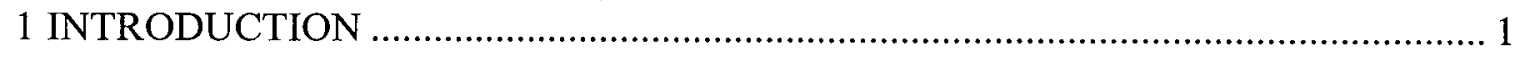

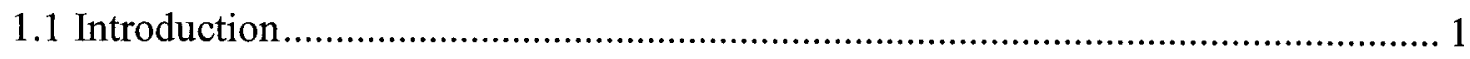

1.2 Structural and functional alterations of blood vessels induced by smoking ............. 2

1.2.1 Effects of smoking on conduit arteries and compliance vessels:...................... 2

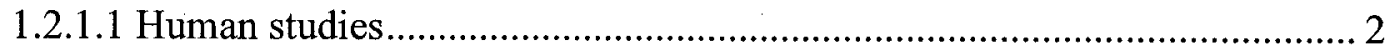

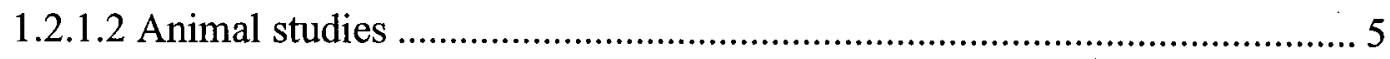

1.2.2 Effects of smoking on small / resistance arteries:......................................... 7

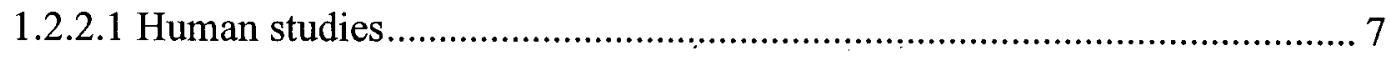

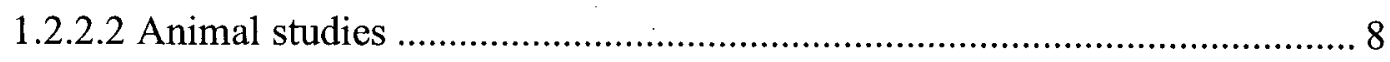

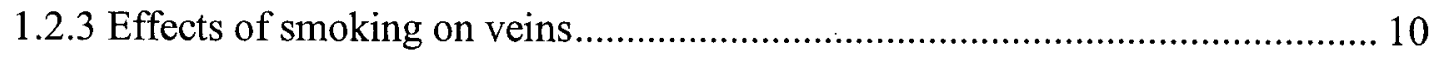

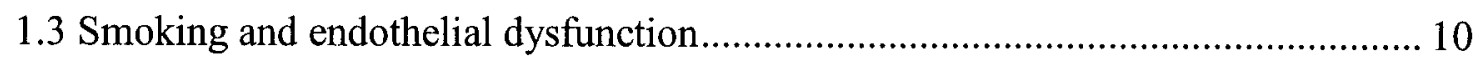

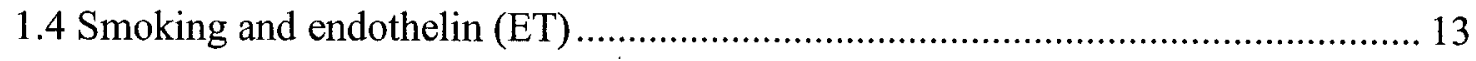

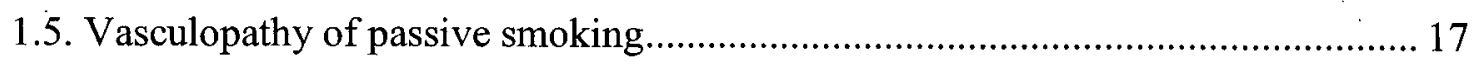

1.6 Molecular mechanisms of vasculopathy induced by cigarette smoking..................22 


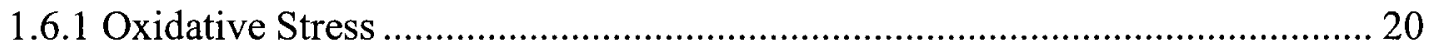

1.6.2 eNOS expression and NO production........................................................ 22

1.6.3 Smoking and development of atherosclerosis................................................ 24

1.6.4 Smoking and matrix metalloproteinases (MMPs) ........................................... 26

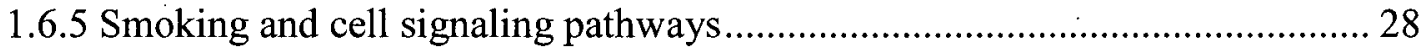

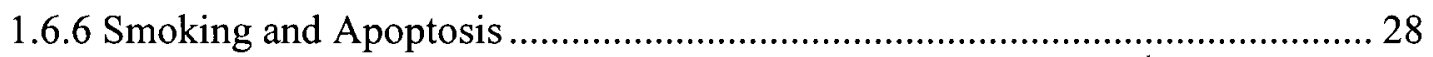

1.6.7 Smoking, gene modulation and vascular immune modulation......................... 29

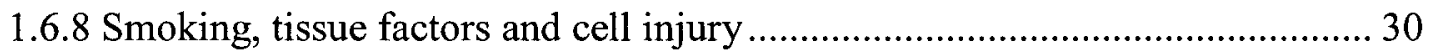

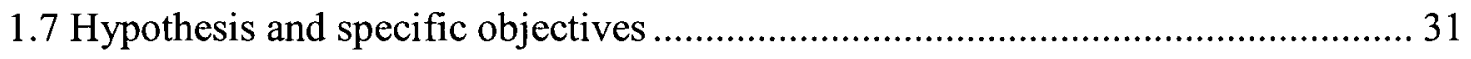

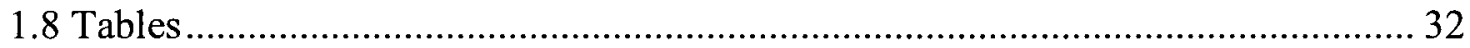

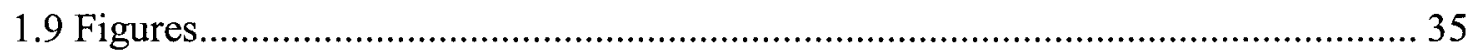

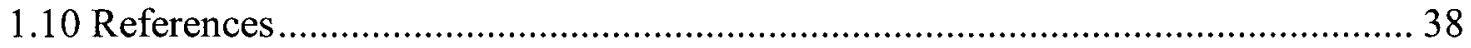

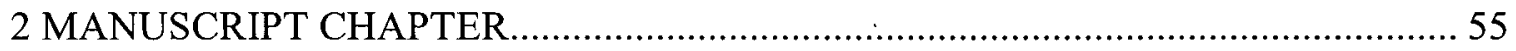

INCREASED VASCULAR CONTRACTILITY IN ISOLATED VESSELS FROM CIGARETTE SMOKING RATS IS MEDIATED BY BASAL ENDOTHELIN

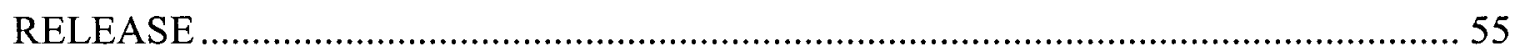

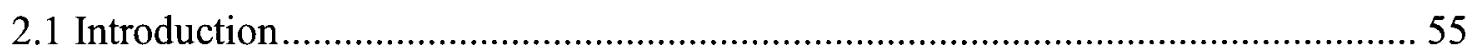

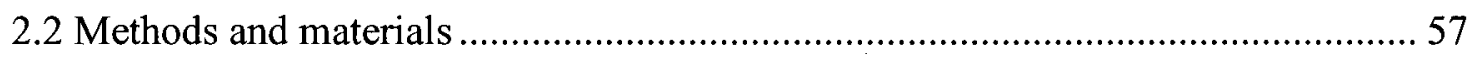

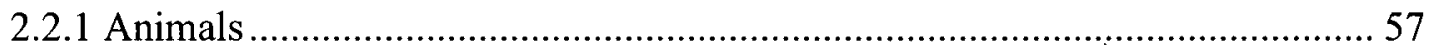

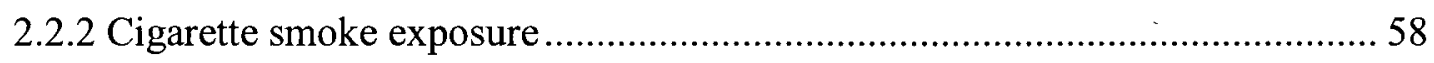

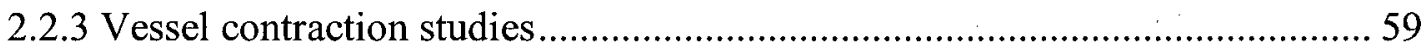

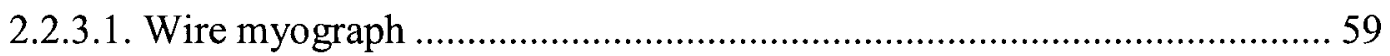

2.2.4. CYP1A1 and CYP1A2 gene expression measured by reverse transcription and 
real-time polymerase chain reaction (RT-PCR) ………......................................... 60

2.2.5. Quantitative assay of plasma ET-1 levels....................................................... 62

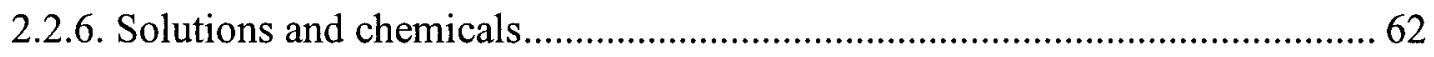

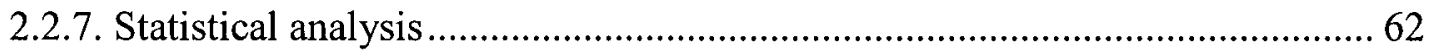

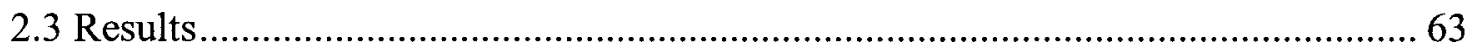

2.3.1 Effects of cigarette smoking on body weight gain...........................................63

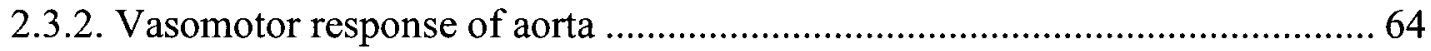

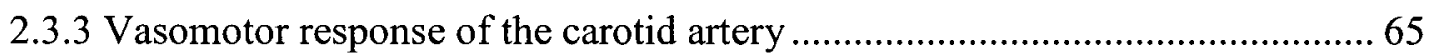

2.3.4 Liver enzyme CYP 1A1 and CYP 1A2 gene expression..................................65

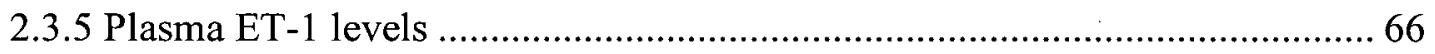

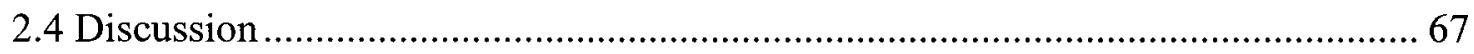

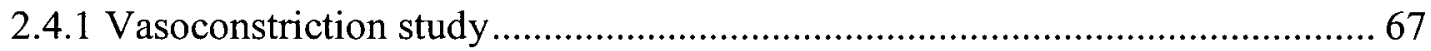

2.4.2 Effect of chronic smoking on CYP1A1 and CYP1A2 gene expression.......... 69

2.4.3. Effects of smoking on plasma ET-1 levels …………..................................... 70

2.4.4 Effects of smoking on body weight gain ........................................................ 71

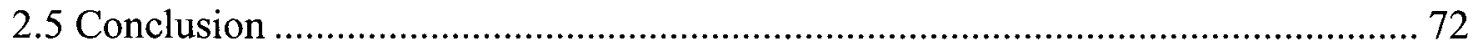

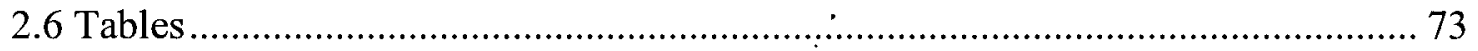

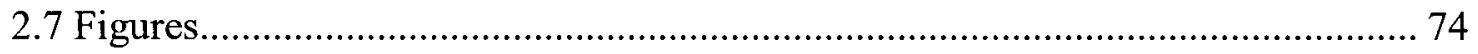

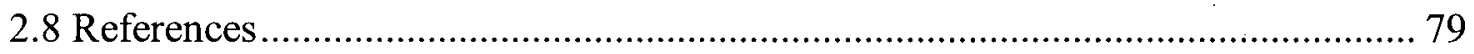

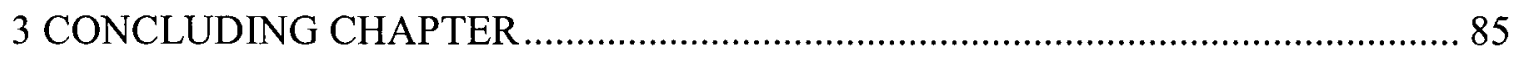

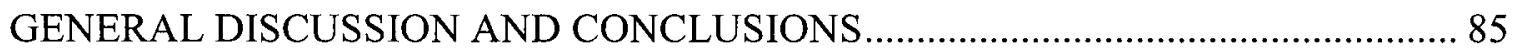

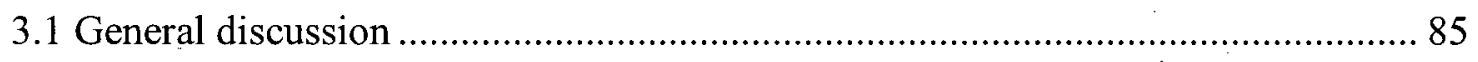

3.2 Comments on strengths and weaknesses of the thesis research........................... 87 
3.3 Evaluation of current knowledge and proposals for new ideas related to the field of study 88

3.4 Discussion of any potential applications of the research findings ...................... 90

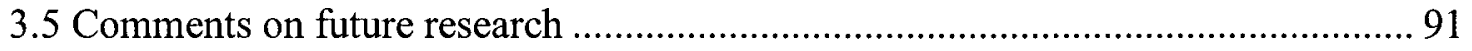

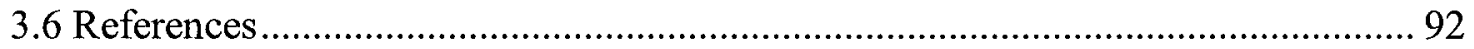

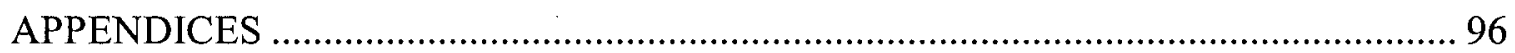

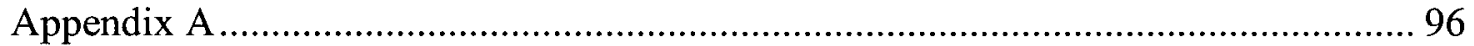

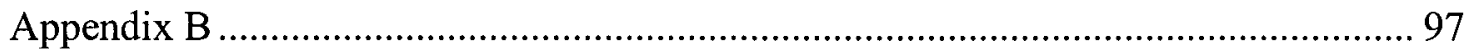

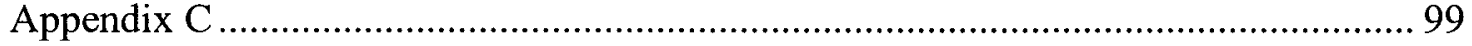

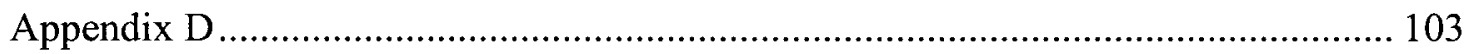




\section{LIST OF TABLES}

Table 1. 1 Cigarette smoke-induced structural alterations in the vasculature. ................. 32

Table 1. 2 Cigarette smoke-induced impairment of endothelium-dependent vasodilation 34

Table 2. 1 Relative mRNA expression (normalized to $18 \mathrm{~s}$ rRNA). 73 


\section{LIST OF FIGURES}

Figure 1. 1 Smoking-induced release of endothelin (ET-1) activates a number of events that lead to dysfunction of the cardiovascular system. ……........................................... 35

Figure 1. 2 Uncoupling of eNOS leads to increased oxidative stress............................... 36

Figure 1. 3 Possible mechanisms of cigarette smoke-induced vasculopathy................... 37

Figure 2. 1 Effect of cigarette smoking on body weight gain.......................................... 74

Figure 2. 2 Contractile response of rat aortae. PE-induced contractions in the absence and presence of bosentan in control and smoking rats........................................................ 75

Figure 2. 3 Contractile response of rat aorta. a. PE-induced contractions in the presence and absence of L-NAME in control rat aortae. b. PE-induced contractions in the presence and absence of L-NAME in smoking rat aortae...................................................... 76

Figure 2. 4 Contractile response of rat carotid arteries. PE-induced contractions in the absence and presence of bosentan in control and smoking rats 77

Figure 2. 5 Results of PCR obtained via block cycler............................................... 78 Figure 2. 6 Plasma levels of ET-1 in non-smoking control $(\mathrm{n}=10)$ and smoking rats $(\mathrm{n}=$ $10)$ 78

Figure 4. 1 Lack of difference in both endothelium-dependent (bradykinin=BK) and independent (sodium nitro prusside $=\mathrm{SNP}$ ) vasodilatation between control and smoking rat middle cerebral artery. 103

Figure 4. 2 Lack of difference in endothelium-dependent $(\mathrm{ACh})$ vasodilatation between control and smoking rat septal coronary artery. 103 


\section{LIST OF SYMBOLS AND ABBREVIATIONS}

$\left[\mathrm{Ca}^{2+}\right]_{\mathrm{i}}$

(C)

20-HETE

$\mathrm{ACh}$

AIx

ANOVA

APC

BH4

BK

BK-Channel

$\mathrm{CaCl}_{2}$

CAD

Calcrl

cDNA

Cfh

cGMP

$\mathrm{CO}$

$\mathrm{CO}_{2}$

COPD

CRP

CSE

CVD

CYP

DMSO

DNA

dsDNA

EDTA
: Intracellular calcium

: Copyright

: 20-hydroxyeicosatetraenoic acid

: Acetyl choline

: Augmentation index

: Analysis of variance

: Activated protein $\mathrm{C}$

: Tetrahydrobiopterin

: Bradykinin

: $\mathrm{Ca}^{+}$-activated potassium channel

: Calcium chloride

: Coronary artery disease

: Calcitonin receptor-like

: Complementary deoxy ribonucleic acid

: Complement factor $\mathrm{H}$

: Cyclic guanosine monophosphate

: Carbon monoxide

: Carbon dioxide

: Chronic obstructive pulmonary disease

: C-reactive protein

: Cigarette smoke extract

: Cardiovascular disease

: Cytochrome P450

: Dimethyl sulphoxide

: Deoxy ribonucleic acid

: Double stranded deoxyribonucleic acid

: Ethylene diamine tetraacitic acid 


\begin{tabular}{|c|c|c|}
\hline EIA & : & Enzyme immunoassay \\
\hline eNOS & : & Endothelial nitric oxide synthase \\
\hline EPCs & : & Endothelial progenitor cells \\
\hline Epxh2 & : & Epoxide hydrolase-2 \\
\hline ET & : & Endothelin \\
\hline ET-1 & : & Endothelin-1 \\
\hline ET-2 & : & Endothelin-2 \\
\hline ET-3 & : & Endothelin-3 \\
\hline ET-4 & : & Endothelin-4 \\
\hline $\mathrm{ET}_{\mathrm{A}}$ & : & Endothelin $_{A}$ \\
\hline $\mathrm{ET}_{\mathrm{B} 1}$ & : & Endothelin $_{B 1}$ \\
\hline $\mathrm{ET}_{\mathrm{B} 2}$ & : & Endothelin $_{\mathrm{B} 2}$ \\
\hline ETS & : & Environmental tobacco smoke \\
\hline FMD & : & Flow-mediated dilation \\
\hline fmol & : & Femto mole \\
\hline GSH & : & Glutathion \\
\hline $\mathrm{H}_{2} \mathrm{O}_{2}$ & : & Hydrogen peroxide \\
\hline HDL & : & High density lipoprotein \\
\hline HUVECs & : & Human umbilical vein endothelial cells \\
\hline ICAM-1 & : & Intercellular adhesion molecule-1 \\
\hline IL-6 & : & Interleukin-6 \\
\hline IMT & : & Intima-media thickness \\
\hline JNK & : & c-jun n-terminal kinase \\
\hline $\mathrm{K}^{+}$-Channel & : & Potassium channel \\
\hline $\mathrm{KCl}$ & : & Potassium chloride \\
\hline $\mathrm{KH}_{2} \mathrm{PO}_{4}$ & : & Potassium dihydrogen phosphate \\
\hline LDL & : & Low density lipoprotein \\
\hline L-NAME & : & $L^{\omega}$-nitro-l-arginine methyl ester \\
\hline M & : & Mole \\
\hline MDA & : & Malondialdehyde \\
\hline $\mathrm{MgSO}_{4}$ & : & Magnesium sulphate \\
\hline
\end{tabular}




\begin{tabular}{|c|c|c|}
\hline MMP & : & Matrix metalloproteinase \\
\hline MMPs & : & Matrix metalloproteinases \\
\hline mRNA & : & Messenger ribonucleic acid \\
\hline $\mathrm{NaCl}$ & : & Sodium chloride \\
\hline $\mathrm{NaHCO}_{3}$ & : & Sodium bicarbonate \\
\hline NCSS & : & Number cruncher statistical system \\
\hline NO & : & Nitric oxide \\
\hline${ }^{\circ} \mathrm{C}$ & : & Degree Celsius \\
\hline $\mathrm{O}_{2}$ & : & Oxygen \\
\hline $\mathrm{O}_{2}^{--}$ & : & Reactive oxygen species \\
\hline $\mathrm{ONOO}^{-}$ & : & Peroxynitrite \\
\hline PAA & : & Precipitating agent additive \\
\hline $\mathrm{PE}$ & : & Phenylephrine \\
\hline $\mathrm{p}^{\mathrm{H}}$ & : & Puissance de hydrogen \\
\hline PH & : & Pulmonary hypertension \\
\hline PKC & : & Protein kinase $\mathrm{C}$ \\
\hline PASS & : & Power analysis and sample size \\
\hline RNA & : & Ribonucleic acid \\
\hline ROS & : & Reactive oxygen species \\
\hline rRNA & : & Ribosomal ribonucleic acid \\
\hline RT-PCR & $:$ & Real-time polymerase chain reaction \\
\hline SE & : & Standard error \\
\hline SEM & : & Standard error of mean \\
\hline SHS & : & Second hand smoke \\
\hline SNP & : & Sodium nitroprusside \\
\hline SOD & : & Superoxide dismutase \\
\hline $\mathrm{TF}$ & : & Tissue factor \\
\hline tPA & : & Tissue plasminogen activator \\
\hline VCAM-1 & : & Vascular cell adhesion molecule-1 \\
\hline Vit-C & & Vitamin C \\
\hline Vit-E & : & Vitamin D \\
\hline
\end{tabular}



VSMC
: Vascular smooth muscle cell
VSMCs
: Vascular smooth muscle cells
$\mu \mathrm{M}$
: Micromole 


\section{GLOSSARY}

\section{Antigen of atherogenesis:}

Oxidized-LDL is considered as the antigen of atherogenesis. It has been suggested that immune responses are involved in atherogenesis. This possibility has been evaluated by analyzing immunocompetent cells in a murine model of the disease. Apolipoprotein E knockout (apoE -/-) mice are genetically hypercholesterolemic due to targeted disruption of the apolipoprotein $\mathrm{E}$ gene and develop severe atherosclerosis. Data obtained from experiments using such mice suggest that CD4+ $\mathrm{T}$ cells participate in the formation of atherosclerotic lesions in genetically hypercholesterolemic apoE -/- mice, and that immune activation is part of the disease process. Thus it is speculated that a direct link may exist between cholesterol accumulation and $\mathrm{T}$ cell activation, possibly by autoimmune responses to modified lipoproteins.

\section{Aortic aneurysm:}

An aneurysm is a bulge in a blood vessel, much like a bulge on an over-inflated inner tube. Aneurysms are dangerous because they may burst. The aorta, the main artery leading away from the heart, can sometimes develop an aneurysm. Aortic aneurysms usually occur in the abdomen below the kidneys (abdominal aneurysm), but may occur in the chest cavity (thoracic aneurysm). This can happen if the wall of the aorta becomes weakened by build-ups of fatty deposits called plaque. This is called atherosclerosis. Aneurysms may also be due to cigarette smoking or to an inherited disease such as the Marfan syndrome.

\section{Aortic systolic pressure:}

Systolic pressure is the pressure of blood against the artery walls when the heart 
has just finished contracting or pumping out blood. Aortic systolic pressure means the blood pressure produced at the root of the aorta. Measurement of central aortic systolic pressure has been taken directly, or estimated indirectly, and has been shown to be superior to brachial pressure in correlating with severity of existing disease and prediction of subsequent events. In most such studies, pressure has been recorded directly at cardiac catheterization or estimated from the carotid pressure or diameter waveform. Non-invasive methods also have been developed, whereby aortic systolic pressure can be generated from the radial pressure waveform using applanation tonometry and applying a generalized transfer function in a computerized process. Aortic systolic pressure has been shown to predict extent and severity of coronary atherosclerosis, independent of brachial pressure.

\section{ApoE mice:}

Mice homozygous for the ApoE -/- (Apolipoprotein E knock out) mutation show a marked increase in total plasma cholesterol levels that are unaffected by age or sex. Fatty streaks in the proximal aorta are found at 3 months of age. The lesions increase with age and progress to lesions with less lipid but more elongated cells, typical of a more advanced stage of pre-atherosclerotic lesion.

\section{Arterial compliance/vascular compliance:}

Compliance is the ability of a blood vessel wall to expand and contract passively with changes in pressure. It is an important property of large arteries and veins. This ability of a vessel to distend with increasing transmural pressure (inside minus outside pressure) is quantified as vessel compliance (C), which is the change in volume $(\Delta \mathrm{V})$ divided by the change in pressure $(\Delta \mathrm{P}) . \mathrm{C}=\Delta \mathrm{V} / \Delta \mathrm{P}$. 


\section{Arterial stiffness:}

It is the opposite function of compliance. Arterial stiffness increases at higher volumes and pressures.

\section{Atherosclerosis:}

Atherosclerosis is a disease affecting arterial blood vessels. It is commonly referred to as a "hardening" or "furring" of the arteries. It is caused by the formation of multiple plaques within the arteries. Pathologically, the atheromatous plaque is divided into three distinct components: (i) atheroma formation involves the nodular accumulation of a soft, flaky, yellowish material at the center of large plaques, composed of macrophages nearest the lumen of the artery, sometimes with (ii) underlying areas of cholesterol crystals, and possibly also (iii) calcification at the outer base of older/more advanced lesions. The following terms are similar, yet distinct, in both spelling and meaning, and can be easily confused: arteriosclerosis, arteriolosclerosis and atherosclerosis. Arteriosclerosis, is a general term describing any hardening (and loss of elasticity) of medium or large arteries (in Latin, Arterio meaning artery and sclerosis meaning hardening), arteriolosclerosis is arteriosclerosis mainly affecting the arterioles (small arteries), atherosclerosis is a hardening of an artery specifically due to an atheromatous plaque. Therefore, atherosclerosis is a form of arteriosclerosis.

\section{Atherothrombosis:}

Atherothrombosis, characterized by atherosclerotic lesion disruption with superimposed thrombus formation, is the major cause of acute coronary syndromes (ACS) and cardiovascular death. It is the leading cause of mortality in the industrialized world. Atherosclerosis is a diffuse process that starts early in 
childhood and progresses asymptomatically through adult life. Later in life, it is clinically manifested as coronary artery disease, stroke, transient ischaemic attack, and peripheral arterial disease.

\section{Augmentation Index (AIx):}

The augmentation index is defined as the proportion of central pulse pressure due to the late systolic peak, which is in turn attributed to the reflected pulse wave. The SphygmoCor system uses an empirically generated transfer function to calculate central pressure from the radial pulse waveform, which is measured by a hand-held tonometer. The same equipment can be used also at other superficial arterial sites, carotid and femoral, and by ECG-gating, the time for transmission of the arterial pulse wave between sites is calculated. This measurement, namely pulse wave velocity, is generally accepted as one of the valid estimates of arterial stiffness.

\section{Bad cholesterol:}

LDL is considered as "bad" cholesterol. When too much LDL cholesterol circulates in the blood, it can slowly build up in the inner walls of the arteries that supply the heart and brain. Together with other substances it can form plaque, a thick, hard deposit that can clog those arteries. This condition is known as atherosclerosis. If a clot forms and blocks a narrowed artery, it can cause a heart attack or stroke. The levels of HDL cholesterol and LDL cholesterol in the blood are measured to evaluate the risk of having a heart attack. LDL cholesterol of less than $100 \mathrm{mg} / \mathrm{dL}$ is the optimal level. Less than $130 \mathrm{mg} / \mathrm{dL}$ is near optimal for most people. A high LDL level (more than $160 \mathrm{mg} / \mathrm{dL}$ or 130 $\mathrm{mg} / \mathrm{dL}$ or above if you have two or more risk factors for cardiovascular disease) reflects an increased risk of heart disease. That's why LDL cholesterol is often called "bad" cholesterol. 


\section{Calcrl:}

A number of endothelial genes undergo dysregulation in response to environmental tobacco smoke. One of those genes is Calcrl (calcitonin receptorlike). Calcrl is part of the receptor complex for adrenomedullin (a vasodilator gene) and calcitonin gene-related peptide, thus associated with vasodilator function, which is impaired in cigarette smokers.

\section{Cfh:}

A number of endothelial genes undergo dysregulation in response to environmental tobacco smoke. One of those genes is $\mathrm{Cfh}$ (complement factor $\mathrm{H}$, or adrenomedullin binding protein-1), which in addition to its established role in regulation of complement activation, has been shown to bind to the vasodilator adrenomedullin and modulate its effects, thus associated with vasodilator function, which is impaired in cigarette șmokers.

\section{CYP 1A1 and CYP1A2:}

These are the genes that encode a member of the cytochrome P450 superfamily of enzymes. These are involved in lipid and drug metabolism. These are inhibited by fluoroquinolones and macrolides; induced by aromatic hydrocarbons, including the aromatic components of cigarette smoke. There are 3 main subtypes of CYP1A: M1, M2 and M3.

\section{Cytochrome P450 enzymes:}

Cytochrome P450 oxidase (abbreviated CYP for mammalian/plant and P450 for bacterial species) is a generic term for a large number of related, but distinct, oxidative enzymes important in animal, plant, and bacterial physiology. The cytochrome $\mathrm{P} 450$, a mixed-function monooxygenase, has about 500 amino acids 
and a heme (hæm) group at the active site. Mammalian and plant cytochrome $\mathrm{P} 450$ s use protein cofactors, cytochrome $\mathrm{P} 450$ reductase and cytochrome $\mathrm{b} 5$, and molecular oxygen $\left(\mathrm{O}_{2}\right)$ to function, while bacterial cytochrome P450s, like cytochrome P450 cam, use other protein cofactors to function. More than 6000 distinct cytochrome P450 sequences are known and officially named. In drug metabolism, cytochrome P450 is probably the most important element of Phase I metabolism in mammals.

\section{DNA-Ladder:}

A DNA ladder is a solution of DNA molecules of different lengths used in agarose gel electrophoresis. It is applied to an agarose gel as a reference to estimate the size of unknown DNA molecules. In addition it can be used to approximate the mass of a band by comparison to a special mass ladder. Different DNA ladders are commercially available depending on expected DNA length. The $1 \mathrm{~kb}$ ladder with fragment ranging from about $0.5 \mathrm{kbp}$ to 10 or 12 $\mathrm{kbp}$ and the $100 \mathrm{bp}$ ladder with fragments ranging from $100 \mathrm{bp}$ to just above $1000 \mathrm{bp}$ are the most frequent. DNA ladders are often produced by a suitable restriction digest of a plasmid. There are special DNA ladders for supercoiled DNA and RNA.

\section{Elastic modulus:}

An elastic modulus, or modulus of elasticity, is the mathematical description of an object or substance's tendency to be deformed when a force is applied to it. The elastic modulus of an object is defined as the slope of its stress-strain curve: $\lambda=$ stress/strain; where $\lambda$ is the elastic modulus; stress is the force causing the deformation divided by the area to which the force is applied; and strain is the ratio of the change caused by the stress to the original state of the object. Because stress is measured in pascals and strain is a unitless ratio, the units of $\lambda$ are therefore pascals as well. An alternative definition is that the elastic modulus 
is the stress required to cause a sample of the material to double in length. This is not literally true for most materials because the value is far greater than the yield stress of the material or the point where elongation becomes nonlinear but some may find this definition more intuitive.

\section{Endothelial dysfunction:}

Endothelial dysfunction may be defined as decreased endothelium-dependent vascular relaxation or NO release, and decreased expression or activity of endothelial NO synthase.

\section{Mainstream, sidestream and environmental tobacco smoke:}

Cigarette smoke that is drawn through the tobacco into an active smoker's mouth is known as mainstream smoke. Sidestream cigarette smoke is the smoke emitted from the burning ends of the cigarette. Environmental tobacco smoke results from the combination of sidestream smoke $(85 \%)$ and a small fraction of exhausted mainstream smoke (15\%) from smokers.

\section{Enzyme immunoassay:}

An assay that uses an enzyme-bound antibody to detect antigen. The enzyme catalyzes a color reaction when exposed to substrate.

\section{Epxh2:}

A number of endothelial genes undergo dysregulation in response to environmental tobacco smoke. One of those genes is Epxh2 (epoxide hydrolase2 , or soluble epoxide hydrolase), which catalyzes the hydrolysis of the endogenous vasorelaxant epoxyeicosatrienoic acid (also known as endothelialderived hyperpolarizing factor. Upregulation of Epxh2 with smoke exposure 
suggests an important role in causing or exacerbating smoke exposure-related hypertension.

\section{Good cholesterol:}

HDL is considered as "good" cholesterol. About one-third to one-fourth of blood cholesterol is carried by high-density lipoprotein (HDL). HDL cholesterol is known as the "good" cholesterol because a high level of it seems to protect against heart attack. (Low HDL cholesterol levels [less than $40 \mathrm{mg} / \mathrm{dL}$ ] increase the risk for heart disease.) Medical experts think that HDL tends to carry cholesterol away from the arteries and back to the liver and excreted from the body. Some experts believe that HDL removes excess cholesterol from plaque in arteries, thus slowing the buildup.

\section{Myogenic tone:}

Myogenic tone originates in the smooth muscle of blood vessels, particularly in small arteries and arterioles. When the lumen of a blood vessel is suddenly expanded, as occurs when intravascular pressure is suddenly increased, the smooth muscles respond by contracting. Conversely, a reduction in intravascular pressure results in smooth muscle relaxation and vasodilation. Electrophysiological studies have shown that vascular smooth muscle cells depolarize when stretched, leading to contraction. Stretching also increases the rate of smooth muscle pacemaker cells that spontaneously undergo depolarization and repolarization. Myogenic tone may play a role in autoregulation of blood flow and in reactive hyperemia. Myogenic behavior has not been clearly identified in all vascular beds, but it has been noted in the splanchnic and renal circulations, and may be present to a small degree in skeletal muscle. 


\section{Myograph:}

The myograph (literal meaning 'muscle writer') is a device we use to measure the force generated by a contracting muscle. Myographs are examples of transducers that convert force into an electrical output that can be displayed on an oscilloscope or a computer monitor.

\section{Polymerase chain reaction (PCR):}

PCR is a molecular biology technique for enzymatically replicating DNA without using a living organism, such as E. coli or yeast. Like amplification using living organisms, the technique allows a small amount of the DNA molecule to be amplified exponentially. However, because it is an in vitro technique, it can be performed without restrictions on the form of DNA and it can be extensively modified to perform a wide array of genetic manipulations. PCR is commonly used in medical and biological research labs for a variety of tasks, such as the detection of hereditary diseases, the identification of genetic fingerprints, the diagnosis of infectious diseases, the cloning of genes, paternity testing, and DNA computing.

\section{Pulse wave velocity:}

Pulse wave velocity is a well-established technique for obtaining a measure of arterial stiffness between two locations in the arterial tree. The velocity of the pulse wave along an artery is dependent on the stiffness of that artery. Most commonly, pulse wave velocity is measured between the carotid and femoral peripheral artery sites in order to provide a measure of aortic stiffness. This aortic pulse wave velocity increases rapidly with age, typically doubling between the ages of 30 and 60.The SphygmoCor Pulse Wave Velocity Vx 
System is sold as an add-on to Px System, and measures the velocity of the blood pressure waveform between any two superficial artery sites. It uses a single-lead ECG and then a tonometer to measure the pressure pulse waveform sequentially in the two peripheral artery sites (eg. carotid \& femoral). When used in conjunction with the SphygmoCor Px System, the system provides a comprehensive assessment of the clinical significance of the arterial stiffness measured.

\section{Reactive oxygen species:}

ROS include oxygen ions, free radicals and peroxides both inorganic and organic. They are generally very small molecules and are highly reactive due to the presence of unpaired valence shell electrons. ROSs form as a natural byproduct of the normal metabolism of oxygen and have important roles in cell signaling. However, during times of environmental stress ROS levels can increase dramatically which can result in significant damage to cell structures. This cumulates into a situation known as oxidative stress. Cells are normally able to defend themselves against ROS damage through the use of enzymes such as superoxide dismutases and catalases. Small molecule antioxidants such as ascorbic acid (vitamin-C), uric acid and glutathione also play important roles as cellular antioxidants.

\section{RT-PCR (Real-time polymerase chain reaction):}

In molecular biology, real-time polymerase chain reaction, also called quantitative real time polymerase chain reaction (QRT-PCR) or kinetic polymerase chain reaction, is a laboratory technique used to simultaneously quantify and amplify a specific part of a given DNA molecule. It is used to determine whether or not a specific sequence is present in the sample; and if it is present, the number of copies in the sample. It is the real-time version of

quantitative polymerase chain reaction (Q-PCR), itself a modification of 
polymerase chain reaction. The procedure follows the general pattern of polymerase chain reaction, but the DNA is quantified after each round of amplification; this is the "real-time" aspect of it. Although real-time quantitative polymerase chain reaction is often marketed as RT-PCR, it should not to be confused with reverse transcription polymerase chain reaction, also known as RT-PCR. 


\section{ACKNOWLEDGEMENTS}

I would like to thank many people and organizations that helped me a lot during my study. First, I am very much grateful to my supervisor, Professor Ismail Laher, for his continuous guidance and kind support during my studies and during the process of my admission to the program. His always-encouraging words and relentless pursuit of scientific excellence and integrity made him an excellent mentor to me.

I am especially grateful to the Heart and Stroke Foundation of BC and Yukon, and the University of British Columbia for providing funding to support my study.

I also express my gratitude to my research committee members, Professors Michael J A Walker, Joanne L Wright, and David V Godin, who provided excellent guidance and scientific feedback during the course of this study and also helped me improve the manuscript by editorial correction.

I would also like to express my sincerest and heartfelt thanks to all my fellow lab mates, with special recognition to Farzad Moien-Afshari, all of whom have helped me to arrive at where I am today.

Special thanks are owed to my parents; who have first shown me the light of education and supported me throughout my years of education, both morally and financially. 
To my parents 


\section{CO-AUTHORSHIP STATEMENT}

The manuscript chapter of this thesis has co-authorship. Identification and design of the research work was done by me (Mohammad Mahmudur Rahman) along with my supervisor Professor Ismail Laher. The majority of the work described in the manuscript (experimental design, data collection, analysis of results, and the writing of the manuscript) was undertaken by myself, with some consultation with the authors whose names are included in the manuscript. Specifically, Dr. T.K.H. Chang carried out the work on the analysis of cytochrome P450 isotyping by RT-PCR. Others listed on the manuscript assisted with discussions and guidance related to specific aspects of the study. 


\section{INTRODUCTION}

\subsection{Introduction}

Cigarette smoking is one of the most important preventable risk factors for cardiovascular disease at a global level (Pechacek et al., 2003). Regardless of gender, smokers have a three-fold increased risk of a heart attack. Even lower levels of exposure of only 8 to 10 cigarettes per day doubles the risk of heart attack in smokers, while smoking only one cigarette daily increases the risk by $6 \%$ (Teo et al., 2006). The current population of smokers throughout the globe is about 1.3 billion (Thun and da Costa e Silva, 2003). During the last century, 100 million people died worldwide as a result of tobacco-related conditions (Mackay and Ericksen, 2002) and it is expected that during this century, about 1 billion people will die of smoking-related diseases (Peto and Lopez, 2001). Cigarette smoking kills 47000 Canadians each year through direct smoking or exposure to environmental tobacco smoke (Teo et al., 2006). Epidemiological surveys suggest that diseases of the heart and blood vessels account for over one-third of deaths in cigarette smokers (Leone et al., 1995). Active smoking is associated with an $80 \%$ increase of coronary artery disease (CAD) whereas passive smoking with a $30 \%$ increase of CAD (Glantz et al., 1991; Law et al., 1997). Thus both active and passive smoking are undoubtedly associated with cardiovascular diseases in both men and women although the particular component(s) of cigarette smoke or the specific mechanism(s) have not yet been fully elucidated. This review chapter focuses on cigarette smoke-induced 
vasculopathy and the molecular mechanisms described so far (Figures 1.3). These data were obtained from in vivo and in vitro studies performed both in humans and experimental animals.

\subsection{Structural and functional alterations of blood vessels induced by smoking}

Clinical and experimental studies investigating cigarette smoke-induced alterations of the structure and function of blood vessels have utilized large conduit arteries, medium muscular arteries, resistance arteries and various sizes of veins, both in humans and animals. These investigations utilized exposure to acute or chronic cigarette smoke and /or nicotine, and even to chronic passive smoking. Cigarette smoke-induced structural alterations in the vasculature are summarized in Table 1.1.

\subsubsection{Effects of smoking on conduit arteries and compliance vessels:}

\subsubsection{Human studies}

Cigarette smoking alters the compliance and stiffening of arteries. Arterial compliance, the ability of a blood vessel wall to expand and contract passively with changes in pressure, is an important function of large arteries and veins. Acute cigarette smoking 
causes a marked reduction in large elastic (Kool et al., 1993; Giannattasio et al., 1994), medium elastic (Kool et al, 1993) and small-sized (Marc et al., 2000) artery compliance accompanied by increases in blood pressure.

Cigarette smoking changes the flow properties of the blood and the stiffness of the arterial wall, which may explain the arterial damage observed in cigarette smoking hypertensive patients. Cigarette smoking is associated with higher levels of blood and plasma viscosity, hematocrit and pulse wave velocity (Levenson et al., 1987) all of which could damage the vessel. Cigarette smoking also increases the immunoreactivity of thromboplastin, an early marker of atherothrombosis (Matetzky et al., 2000).

Acute cigarette smoking reduces the distensibility of both medium-sized muscular arteries as well as large elastic arteries, thereby causing systemic artery stiffening. Adrenergic mechanisms are most likely responsible for alterations in arterial distensibility (Failla et al., 1997). Acute cigarette smoking increases arterial stiffness in large arteries in healthy young chronic smokers and nonsmokers with a higher aortic systolic blood pressure (Mahmud and Feely, 2003) but these changes are more prominent in chronic smokers (Kim et al., 2005). Chronic tobacco smoking is associated with endothelial dysfunction in arteries exhibiting increased stiffness as evidenced by a greater augmentation index (AIx) in subjects free of other cardiovascular risk factors (Rehill et al., 2006).

Several clinical and experimental studies demonstrate that smoking is associated with increases in the intima media thickness ratio (IMT) or arterial wall thickness in carotid 
(Poredos et al., 1999; van den Berkmortel et al., 2000), femoral (van den Berkmortel et al., 2000) and brachial arteries (Esen et al., 2004) of both chronic and acute smokers. Resting blood flow and endothelium-dependent flow-mediated dilation (FMD) of brachial (Lekakis et al., 1997; Poredos et al., 1999; Tanriverdi et al., 2006) and epicardial (Zeiher et al., 1995) arteries are significantly impaired in smokers. Impairment of FMD and increased IMT are related to the duration and the number of cigarettes smoked. Thus smoking is associated with a dose- and/or time-related impairment of FMD and increased IMT of large human arteries. Increased wall thickness and impairment of endotheliumdependent dilation of arteries suggests that cigarette smoking distorts the vessel wall long before atherosclerosis is manifest. Most of these studies were performed in heterogeneous groups of elderly subjects predisposed to atherosclerotic disease or with other cardiovascular risk factors. However, a study performed in otherwise healthy middle-aged smokers demonstrated that cigarette smoking as a single cardiovascular risk factor causes wall thickening in carotid and femoral arteries (van den Berkmortel et al., 2000). This raises the possibility that cigarette smoking is a preventable cause of early atherosclerosis in otherwise healthy subjects.

The aorta acts as both a conduit and an elastic buffering chamber that modulates left ventricular output and coronary blood flow. Both active and passive smoking causes deterioration in the elastic properties of the aorta in humans (Stefanadis et al., 1998). A large epidemiological survey suggests that atherosclerotic disease is associated with a higher risk of abdominal aortic aneurysm, and that cigarette smoking increases the risk of aortic aneurysm independently of atherosclerosis (Lee et al., 1997). These effects could 
be due to a loss of elastic properties of the abdominal aorta caused by smoking. The smoking of only one cigarette raises systolic and diastolic blood pressures, increases vascular resistance, impairs baroreflex activity and increases carotid artery wall tension in mild smokers (Arosino et al., 2006).

It is now established that acute and chronic smoking reduces peripheral blood flow and shear stress, contributing to an increased incidence of peripheral arterial disease in sedentary smokers. Studies designed to determine whether physical activity influences peripheral blood flow in chronic smokers demonstrated that basal femoral artery blood flow was $\sim 50 \%$ higher in physically active smokers compared to that in sedentary smokers (Anton et al., 2006).

\subsubsection{Animal studies}

The terms acute, short-term and long-term are sometimes not very precise, but from different experimental (animal) models of cigarette smoking it is clear that exposure to one or more cigarettes for one time only is referred to as acute, whereas exposure to one or more cigarettes for few days to few weeks is referred to as short-term, and exposure to one or more cigarettes for few weeks to few months or even years is referred to as longterm or chronic smoking (Guo et al., 2006; Warner et al., 2006; Wright et al., 1997).

In various animal models, chronic exposure to cigarette smoke or acute exposure to cigarette smoke extract (CSE) resulted in impaired endothelium-dependent vasodilation, 
increased intimal thickening and/or hyperplasia, atherosclerotic plaques, aneurismal dilation and increased tone in the aorta as well as. in other large and medium-sized arteries.

In pig pulmonary arteries, cigarette smoke extract caused a biphasic response in blood vessels with an intact endothelium: relaxation at lower concentrations and contraction at higher concentrations (Holden et al., 1990). Cigarette smoke releases endothelin, which at lower concentrations acts predominantly on $\mathrm{ET}_{\mathrm{BI}}$ receptors localized on the endothelium producing NO and prostacyclin, resulting in vasorelaxation. The contraction was due to activation of thromboxane $\mathrm{A} 2$ and $\mathrm{PKC}$ and to a direct effect of $\mathrm{ET}-1$ on $\mathrm{ET}_{\mathrm{A}}$ and $\mathrm{ET}_{\mathrm{B} 2}$ receptors located on the vascular smooth muscle. Both nicotine and cigarette smoke caused endothelium-dependent contraction of intrapulmonary arteries but the contractile response to CSE was greater than with nicotine alone (Holden et al., 1990). We recently reported that chronic exposure to mainstream smoke significantly increased arterial tone through ET-1-dependent mechanisms (Rahman et al., 2006). Chronic exposure to cigarette smoke (Jorge et al., 1995) and acute exposure to cigarette smoke-treated Krebs buffer (Raij et al., 2001) impaired endothelium-dependent vasorelaxation in rat and rabbit aortas (Ota et al., 1997).

Short-term (one week) exposure of Sprague Dawley rats and long-term (five weeks) exposure of apo $\mathrm{E}$ deficient mice increased intimal hyperplasia in the rat carotid (Petrik et al., 1995), produced wall thickening in rat pulmonary (He et al., 1991), and augmented thickening in mouse carotid (Tani et al., 2004) arteries, leading to the possibility that 
cigarette smoke is a significant risk factor in developing arterial restenosis. Intimal thickening or hyperplasia can also lead to atherothrombotic diseases in smokers. Smoking is known to increase atherothrombotic plaques. Aortic root plaques of apo E deficient mice (genetically hypercholesterolemic) exposed to cigarette smoke had higher immunoreactivity for tissue factor, vascular cell adhesion molecule-1, and macrophages (all features relating to atherosclerosis) compared with non-smoking controls (Matetzky et al., 2000).

Cigarette smoking also increases the risk for developing abdominal aortic aneurysms. Long-term (12 weeks) exposure to cigarette smoke significantly increases (50\% greater dilatation in smoking mice than the controls) the progression of aneurismal dilatation of the abdominal aorta of mice, while short-term ( 2 weeks) exposure was without effect on the initial development of abdominal aortic aneurysms (Buckley et al., 2004). The effects of cigarette smoking may be due to detrimental changes in elastic properties of the aorta.

\subsubsection{Effects of smoking on small / resistance arteries:}

\subsubsection{Human studies}

There are scant reports on the effects of cigarette smoking in human resistance arteries, reflecting the difficulty in obtaining these vessels for in vitro studies. However, a study investigating the effect of long-term smoking on coronary vasomotion and vasodilator 
capacity in healthy smokers implicated abnormal endothelial function that was related to the duration of smoking (Campisi et al., 1998). In a more recent study, human middle cerebral arteries obtained at autopsy were incubated with lipid soluble smoke particles for 6 to 48 hours, causing the endothelium to swell and detach from its underlying structures. Lipid soluble smoke particles, but not nicotine, impaired endothelium-dependent dilatation (Zhang et al., 2006).

\subsubsection{Animal studies}

Chronic cigarette smoke in rats reduces coronary blood flow (Jorge et al., 1995) and chronic nicotine exposure decreased cerebral blood flow (Gerzanich et al., 2001). Chronic cigarette smoke increases pulmonary arterial pressure in guinea pigs (Wright et al., 1991) and coronary arterial pressure in mice (Guo et al., 2006). Lipid soluble smoke particles, but not nicotine, impairs endothelium-dependent dilatation in rat mesenteric arteries (Zhang et al., 2006) while the smoking of a single cigarette causes dysfunction of endothelium-dependent, but not endothelium-independent, vasodilation in rat cerebral arteries (Iida et al., 2006).

Smoking a single cigarette causes a biphasic response in the cerebral circulation of rats where there is an initial constriction that is followed by vasodilatation (lida et al., 1998). Porcine coronary artery exposed to CSE also has a biphasic response (Murohara et al., 1994). The initial increase in tone is likely due to the breakdown of NO by superoxide anions derived from CSE or due to ET-1 effects on $\mathrm{ET}_{\mathrm{A}}$ receptors of arterial smooth 
muscle cells.

Among the different chemical constituents of cigarette smoke, nicotine is considered the most potent vasoconstrictor. Nicotine exposure potentiated norepinephrine-induced vasoconstriction in hamster cheek pouch arterioles (Mayhan et al., 1999), while the contractility of canine cerebral arteries wass increased by nicotine through impairment of endothelial function and activation of PKC activity (Koide et al. 2005). Chronic nicotine exposure blunted NO-induced vasodilation (Gerzanich et al., 2001), suggesting vascular smooth muscle dysfunction as an additional component. This may be due to muscularization by ET-1, a potent mitogen. In a guinea pig model of chronic (up to 1 year) cigarette smoking, there was increased muscularization of the pulmonary arterioles producing pulmonary hypertension (Wright et al., 1991).

Chronic exposure of guinea pigs to cigarette smoke increased endothelin levels and vascular endothelial growth factor expression for the duration of the exposure period. It is likely that cigarette smoking triggers the production of endogenous factors that control long-term artery remodeling and vascular tone (Wright et al., 2004). This remodeling was also evident in rat mesenteric resistance arteries incubated with lipid soluble smoke particles where the arterial endothelium was swollen with loose attachment to underlying structures (Zhang et al., 2006). Cigarette smoking also increased the elastic modulus, wall thickness, and the wall thickness-to-radius ratio in mouse coronary arteries (Guo et al., 2006) 


\subsubsection{Effects of smoking on veins}

The functional consequences of cigarette smoking on venous function have not been extensively studied in either humans or experimental animals. Smoking causes a thickening of the endothelial basal lamina (Higman et al., 1994) and impairs endotheliumdependent relaxation of saphenous veins (Higman et al., 1996; Freischlag et al., 1999). In humans, acute exposure of dorsal hand veins of healthy non-smokers to nicotine is associated with a blunted vasodilatory response to bradykinin, an endothelium-dependent vasodilator (Chalon et al., 2000; Sabha et al., 2000). Loss of endothelial viability due to increased apoptosis is another possible cause of smoking-induced impairment of vasodilation, as shown in isolated human umbilical vein endothelial cells (Wang et al., 2001).

\subsection{Smoking and endothelial dysfunction}

Cigarette smoking is a cardiovascular disease risk factor that is strongly associated with endothelial dysfunction (Verma and Anderson, 2002). An important manifestation of endothelial dysfunction is decreased endothelial-dependent vasodilatation due to reduced NO bioavailability that is possibly associated with a decreased expression or activity of endothelial NO synthase (eNOS). Endothelium-derived relaxation and/or production of endothelium-derived NO from the amino acid L-arginine by eNOS can be used as an indicator of endothelial function. However, the majority of clinical and experimental studies investigating cigarette smoke-induced endothelial dysfunction have monitored 
impairment of endothelium-dependent vasorelaxation (Summarized in Table 2). Some studies report that cigarette smoke reduces eNOS expression and the associated NO production (McVeigh et al., 1996; Su et al., 1998; Wang et al., 2000; Barbera et al., 2001; Barua et al., 2001), while one study shows that whole cigarette smoke, but not nicotine itself, causes endothelial dysfunction (Zhang et al., 2006). However, it is important to stress that the majority of investigations demonstrate that both cigarette smoke and nicotine causing endothelial dysfunction (Table 1.2).

Impaired vasodilation due to reduced stimulated release or attenuated basal production of endothelium-derived nitric oxide is generally regarded as a useful marker of early changes in endothelial cells that can precede morphologic changes (Anggard E, 1994; Cohen et al., 1988). Long-term smokers without clinical evidence of vascular disease have abnormal endothelial function as manifested by a reduction in basal, but not stimulated, nitric oxide-mediated vasodilation (McVeigh et al., 1996). Acute smoking also produces a relatively brief period of endothelial dysfunction, while short-term smoking causes a substantial increase in blood pressure and heart rate along with increased circulating and locally released catecholamines (Lekakis et al., 1997). Both short-term smoking and nicotine chewing gum reduce endothelial-dependent vasodilation in the forearms of young habitual smokers (Sarabi and Lind, 2000). However, a more recent study suggests that lipid soluble smoke particles, but not nicotine, significantly impair endothelium-dependent dilatation in rat mesenteric and human middle cerebral arteries (Zhang et al., 2006). 
There is also an isolated study showing that cigarette smoking paradoxically improves (by approximately $5-10 \%$ ) endothelial-derived vasorelaxation in rat carotid arteries, possibly through hypoxia-induced production of carboxyhemoglobin (Nene et al., 1997).

A surprising finding, although an isolated one, is that smoking increases aortic endothelial regeneration after balloon injury as well as increasing serum nitric oxide levels in rats (Sarker et al., 1999), while a more recent study reports that cigarette smoke impedes the endothelial repair process in pig pulmonary artery cells (Su at al., 2004). In pig pulmonary artery cells, cigarette smoke extracts decreased monolayer wound repair, tube formation, cell migration and proliferation, suggesting that impaired angiogenesis may impede the repair process in the lungs of cigarette smokers and contribute to the altered structural remodeling observed in the lungs of patients with cigarette smoke-related COPD (Su at al., 2004). A new study by Michaud et al (2006) extended the findings of Su et al by demonstrating that endothelial progenitor cell (EPC) dysfunction could contribute to impaired blood vessel healing and growth in smokers. Cigarette smoking reduces the number of EPCs and impedes their differentiation and functional activity (Michaud et al., 2006).

Measuring circulating endothelial modulators can also monitor the interaction of cigarette smoking on endothelial function. For example, cigarette smoking decreases the levels of the antioxidants Vit-C and Vit-E, while it increases E-selectin, ICAM-1, VCAM-1 and ET-1 (Winkelmann et al., 2001; Ueno et al. 2006; Rahman et al, 2006). 


\subsection{Smoking and endothelin $(\mathbb{E} T)$}

The presence of a vasoconstrictor peptide secreted from vascular endothelium was first reported in 1985 (Hicky et al, 1985); thereafter, endothelin, one of the most potent endogenous vasoconstrictors known to date, was isolated from the supernatant of cultured porcine endothelial cells (Yanagisawa et al., 1988). Endothelin is 100 times more potent than norepinephrine and 10 times more potent than angiotensin II on a molar basis. Endothelin has important roles in the pathogenesis of cardiovascular disorders due to its powerful vasoconstrictor and mitogenic properties (Yanagisawa et al., 1988; and Naruse et al., 1994). Since the discovery of endothelin, four isoforms have been described: ET-1, ET-2, ET-3, and ET-4. These peptides are produced in a variety of tissues, including the vascular endothelium and smooth muscle cells, where they act as modulators of vasomotor tone, cell proliferation and hormone production (Luscher et al., 1992).

The major isoform of endothelin acting in the cardiovascular system is ET-1 which is produced by both endothelial cells and vascular smooth muscle cells (Levin et al., 1995). Stimuli for ET-1 release include hypoxia, shear stress, endotoxin, epinephrine, vasopressin, angiotensin II, thrombin, interleukin-1- $\beta$ and cigarette smoking (Luscher et al., 1992; and Lee et al., 2001). ET-1 acts on three types of G-protein-coupled receptors: $\mathrm{ET}_{\mathrm{A}}, \mathrm{ET}_{\mathrm{B} 1}$ and $\mathrm{ET}_{\mathrm{B} 2}$ (Douglas et al., 1995). Of these receptors, $\mathrm{ET}_{\mathrm{A}}$ and $\mathrm{ET}_{\mathrm{B} 2}$ receptors are expressed in vascular smooth muscle cells, while $\mathrm{ET}_{\mathrm{B} 1}$ is predominantly located in the vascular endothelium. Endothelin receptors on vascular smooth muscle cells mediate vasoconstriction while those on the endothelium modulate NO and prostacyclin release 
(de Nucci et al., 1988; Sakurai et al., 1990; and Arai et al., 1990). Low concentrations of ET-1 act mainly on $\mathrm{ET}_{\mathrm{B} \text { I }}$ receptors to cause vasodilation (de Nucci et al., 1988; Masaki et al., 1995).

Several reports implicate ET-1 activation in cardiovascular and pulmonary tissues as a result of cigarette smoking. Long-term smoking impairs endothelium-dependent vasodilator responses produced by low-concentrations of ET-1, whereas short-term smoking enhances ET-1-induced vasoconstriction in human brachial arteries (Kiowski et al., 1994).

Endothelin is a potent mitogen (Hirata et al., 1989) and can alter smooth muscle cell responses to other vasoactive agents (Thorin et al., 1998). Rabbit airway smooth muscle cell cultures exposed to cigarette smoke extract have increased proliferation via release of ET-1 and its associated autocrine mitogenic actions (Fang et al., 1997). Endothelin release also modulates the effects of acute cigarette smoking on cell proliferation in the rat airways and pulmonary arterial vessels, (Wright et al., 2001) in addition to mediating vasoconstriction in rat bronchioles (Wright et al., 1999) and rat carotid arteries (Rahman et al, 2006).

Acute cigarette smoke exposure (30 minutes) increases expression of ET-1 mRNA in rat hearts and lungs, while chronic exposure (6 months) did not alter the expression of ET-1 mRNA (Adachi et al., 2000). Related to this are findings that the gene expression and content of ET-1 in pulmonary artery endothelium is similar in smoker and control groups 
(Barbera et al., 2001) and that ET-1 biosynthesis is similar in nonsmokers, light and heavy smokers (Barua et al., 2002). In contrast, Wright et al (2002) report an upregulation of ET-1 gene expression in pulmonary arteries 2 hours after smoke exposure. It is unclear why chronic cigarette smoking does not lead to increased ET-1 mRNA expression even though plasma levels of ET-1 are often increased (e.g. Rahman et al, 2006)

Although cigarette smoking causes the release of ET-1, it is unclear if this results from augmented ET-1 mRNA. The levels of ET-1 are raised in chronic smokers with hyperlipoproteinemia (Haak et al., 1994a). Smoking-induced increases in plasma ET-1 are detected within 10 minutes of exposure to smoke (Haak et al., 1994; and Goerre et al., 1995). In addition to nicotine, other smoke components, such as CO or tar, may also be responsible for the increased plasma ET-1 levels in smokers (Goerre et al., 1995). Nicotine alone can stimulate ET-1 production in cultured human endothelial cells within 5 minutes of cigarette smoke exposure (Lee et al., 1999) and increase plasma ET-1 levels in nonsmokers within 15 minutes after chewing nicotine gum (Letizia et al, 1997). As a general rule, plasma ET-1 concentrations in human cigarette smokers are significantly elevated (Orem et al., 2001). The increases in ET-1 are persistent, as shown in a study of nearly 1500 chronic smokers with significantly increased raised plasma immunoreactive ET-1 (Hirai et al, 2004) Cigarette smoking-induced increases in plasma ET-1 may also lead to tissue hypoxemia and decreases in peripheral glucose utilization (Borissova et al., 2004).

In addition to stimulating ET-1 secretion by increasing its gene transcription (Adachi et al 
2000) a recent study (Granstrom et al., 2006) also presents evidence that cigarette smoke increases $\mathrm{ET}_{\mathrm{A}}$ and $\mathrm{ET}_{\mathrm{B}}$ receptors in the smooth muscle cells of rat bronchial segments, possibly through increased translation rather than transcription.

Hashimoto et al (2004) reported that intraportal nicotine infusion in rats inhibits hepatic circulation through ET-1 and ETA and ETB receptors (Hashimoto et al., 2004). This inhibition of hepatic circulation may be due to endothelin-induced vasoconstriction and/or desensitization of vasodilatory mechanism. A subsequent study by Migneault et al (2005) reported that chronic increases in endothelin reduced the pulmonary vasodilator reserve in response to nitric oxide. These results suggest that chronic cigarette smoking causes chronic increases in plasma endothelin, which in turn causes desensitization of the vasodilatory mechanism and enhances the progression of atherosclerosis (Fig 1.1). In vitro studies suggest that the binding of ET-1 to its receptor activates protein kinase C (PKC) (Griendling et al., 1989; and Danthuluri et al., 1990). More specifically, ET-1 activates the $\alpha$ isoforms of PKC (PKC- $\alpha$ ) in cultures of endothelial cells, thus deranging cellular integrity (Kuklin et al., 2005).

Nitric oxide (NO) produced by the vascular endothelium is a potent vasodilator with antiatherosclerotic properties. On the other hand ET-1, also produced by the vascular endothelium, is a potent vasoconstrictor having mitogenic and proliferative activity on vascular smooth muscle cells. In human athletes, acute exercise (for only 30 minutes) transiently increases plasma ET-1 levels (Maeda et al, 1997) but chronic exercise (6 weeks) significantly decreases the plasma ET-1 levels and increases production of NO 
(Maeda et al., 2001), suggesting beneficial effects of exercise on the cardiovascular system. Cigarette smoking-induced increases in plasma ET-1 levels limit both exerciseinduced vasodilation and the blood flow redistribution to active muscles (Doutreleau et al., 2004). A recent study designed to investigate whether physical activity influences peripheral blood flow in chronic smokers reports that basal femoral artery blood flow was $\sim 50 \%$ higher in physically active smokers compared with sedentary smokers (Anton et al., 2006). Thus, regular exercise could help, at least to some extent, in delaying atherosclerosis and other vasculopathies by increasing NO production and decreasing ET1 levels in chronic smokers.

\subsection{Vasculopathy of passive smoking}

Passive smoking, also known as second hand smoke (SHS) or environmental tobacco smoke (ETS), is a preventable risk factor for cardiovascular morbidity and mortality (Taylor et al., 1992; Zhu et al., 1994; and Kritz et al., 1995). One report suggests that coronary disease mortality is increased by $20 \%$ in spouses of smokers, an effect that was ascribed to ETS (Steenland et al., 1996). Of the more than 200000 yearly deaths due to myocardial infarction in the United States, it is estimated that between 35000 to 40000 patients die as result of ETS exposure (Scott et al., 1996), while another estimate is that of the nearly 480000 smoke-related deaths that occur every year in the United States, about 53000 are attributable to ETS (Glantz et al., 1991). A study of non-smoking female nurses concluded that regular exposure to passive smoking at home or work increased the risk of coronary heart disease (Kawachi et al., 1997), so that there can be up to a $25 \%$ 
increase in the risk of coronary heart disease among nonsmokers (He et al., 1999). Even occasional ETS increases the risk of developing an acute coronary syndrome, especially when other risk factors are present (Panagiotakos et al., 2000). High levels of exposure to SHS of 22 hours or more per week can increase the risk of developing a heart attack by nearly $45 \%$ (Teo et al., 2006). These epidemiological findings are in keeping with the observation that passive smoking causes a substantial reduction of coronary flow velocity reserve in healthy nonsmokers (Otsuka et al., 2001), as well as leading to a deterioration of the elastic properties of human arteries (Stefanadis et al., 1998). Thus it is clear from environmental and experimental studies that passive smoking is no less harmful than active smoking, with both sharing similar mechanisms. In addition, the particle size present in ETS is smaller than that in the mainstream smoke (Kritz et al., 1995), causing the more dangerous smaller particles $(<2.5 \mu \mathrm{M})$ to be deeply lodged in the bronchioles.

There are several proposed mechanisms by which passive smoking affects the cardiovascular system, including reducing oxygen carrying capacity of blood (Glantz et al., 1995), increasing platelet activation (Glantz et al., 1995), promoting endothelial damage (Celermajer et al., 1996) and accelerating atherosclerosis (Zhu et al., 1993). Passive smoking increases atherosclerosis in the cholesterol-fed rabbit (Zhu et al., 1993) and in cockerels (Penn et al., 1994). Animals exposed to ETS have increased infarct sizes after coronary artery ligation (Prentice et al., 1989; Zhu et al., 1994; Zhu et al., 1996), as well as increased numbers of plaques in aorta (Penn et al., 1993), with a greater atherosclerotic surface area (Zhu et al., 1993; Sun et al., 1994). In nearly 11000 participant humans at risk for developing atherosclerosis, Howard et al (1998) found that 
exposure to active smoke increased carotid intima-media thickness by $50 \%$, while ETS increased this by $20 \%$. Passive smoking causes a dose-related deterioration of endothelium-dependent vasodilation in healthy young adults, suggesting that this early arterial damage may be the starting point of atherosclerotic heart disease (Celermajer et al., 1996).

In utero and neonatal exposure to ETS causes vascular dysfunction in newborn rats. Aortic rings from newborn rats showed reduced maximal endothelium-dependent vasodilation to acetylcholine and also decreased sensitivity to the endotheliumindependent vasodilator nitroglycerin, suggesting a detrimental effect of ETS on vascular smooth muscle function (Hutchison et al., 1998). In passive as well as active smokers, coronary arterial dysfunction can be confirmed by quantitative coronary angiography (Sumida et al., 1998). Passive smoking impairs endothelium-dependent relaxation of isolated rabbit thoracic aorta and coronary artery, with the impaired arterial relaxation possibly due to the increased degradation of released NO by superoxide anion derived from cigarette smoke (Torok et al., 2000). Direct evidence for production of free radicals by passive smoking is the raised level of plasma isoprostanes (a reliable marker of in vivo oxidative stress) following exposure to second hand smoke (Ahmadzadehfar et al., 2006). 


\subsection{Molecular mechanisms of vasculopathy induced by cigarette smoking}

Cigarette smoking-induced vasculopathy involves different factors, ion channels, and cell signaling pathways (summarized in figure 1.3).

\subsubsection{Oxidative Stress}

Oxidative damage of cells can result from a combination of the following: 1) an increase in oxidant generation, 2) a decrease in antioxidant protection, or 3) a failure to repair oxidative damage. Oxidative damage is caused by reactive oxygen species (ROS), which includes, but is not limited to, superoxide, singlet oxygen, peroxynitrite or hydrogen peroxide. Under normal conditions, ROS are cleared from the cell by the action of superoxide dismutase (SOD), catalase, or glutathione (GSH) peroxidase. An important component of cell damage results from ROS-induced alterations of macromolecules such as polyunsaturated fatty acids in membrane lipids, essential proteins, and DNA. Most ROS originate from endogenous sources as by-products of normal and essential metabolic reactions, such as energy generation from mitochondria or the detoxification reactions involving hepatic cytochrome P-450 enzymes. Exogenous sources of ROS include exposure to cigarette smoke, environmental pollutants, excessive consumption of alcohol, exposure to ionizing radiation or asbestos, and bacterial, fungal or viral infections (Fiers et al., 1999; Nicholls and Budd, 2000; Hayes and McLellan, 1999). 
Cigarette smoke is a rich source of free radicals (Pryor et al., 1993), there being two main categories: gas-phase radicals, which are only stable for a short duration (seconds), and tar-phase radicals, which are stable for hours to months (Smith et al., 2001; Pryor et al., 1993; and Pryor et al., 1998). These tar-phase radicals auto-oxidize to form $\mathrm{O}_{2}{ }^{-“}$ and $\mathrm{H}_{2} \mathrm{O}_{2}$ in biological fluids (Pryor et al., 1993; and Pryor et al., 1998), and markedly affect NO bioavailability. Cigarette smoking increases vascular superoxide production, resulting in decreased NO bioavailability and increased production of cyclooxygenase-dependent and -independent vasoconstricting eicosanoids (Raij et al., 2001). Human coronary arterial endothelial cells incubated with smokers' serum have significantly lower NO production and eNOS activity but have increased eNOS expression, likely due to an increased production of $\mathrm{H}_{2} \mathrm{O}_{2}$ (Barua et al., 2003).

Anti-oxidants such as $\alpha$-tocopherol and ascorbic acid exert differential protective effects on cigarette smoke extract-induced DNA damage and cell adhesion molecule expression in HUVECs (Chen et al., 2004). Cigarette smoke extract-induced inhibition of endothelial-dependent vascular relaxation is attenuated by free radical scavengers such as SOD, DMSO or by captopril, an angiotensin converting enzyme inhibitor. It is likely that captopril attenuates CSE-induced endothelial dysfunction partly through scavenging free radicals (Ota et al., 1997). Short-term exposure of bovine pulmonary arterial endothelial cells to cigarette smoke causes a large increase in superoxide $\left(\mathrm{O}_{2}{ }^{-}\right)$production while acrolin, a stable thiol-reactive agent found in cigarette smoke, increases $\mathrm{O}_{2}{ }^{-}$production 5fold. The effects of acrolin were prevented by prior inhibition of NADPH oxidase, suggesting that thiol-reactive stable compounds in cigarette smoke activate NADPH 
oxidase and increase endothelial $\mathrm{O}_{2}{ }^{-}$production, thereby reducing NO bioavailability, resulting in endothelial dysfunction (Jaimes et al., 2004). The smoking-induced increase in oxidative stress can be monitored by measuring significantly higher levels of superoxide dismutase (SOD) and malondialdehyde (MDA) and lower levels of reduced glutathione (GSH) in subjects with normal coronary arteries; under these conditions, there is also a deterioration of coronary blood flow (Tanriverdi et al., 2006).

Tetrahydrobiopterin (BH4) is an essential cofactor for eNOS. Cigarette smoke-derived $\mathrm{O}_{2}-$ reacts with NO giving rise to preoxynitrite (ONOO-), which depletes the $\mathrm{BH} 4$ reserve by oxidation (Heitzer et al., 2000). A deficiency of BH4 results in uncoupling of the eNOS enzyme (Figure 1.2), which then produces $\mathrm{O}_{2}{ }^{-}$instead of NO (Heitzer et al., 2000; and Vasquez-Vivar et al., 1998). Several studies using either in vivo or in vitro smoking models confirm that that addition of exogenous $\mathrm{BH} 4$ will increase NO availability (Higman et al., 1996; Heitzer et al., 2000; and Heitzer et al., 2000;et al., 2000). These studies strongly suggest that free radical-mediated oxidative stress is central to the progression of atherosclerotic changes and vasomotor dysfunction in smokers (Kojda et al., 1999; and Nedeljkovic et al., 2003). Antioxidant agents have been found to either improve or reverse the atherosclerotic conditions in animal models of smoking or in human smokers (Heitzer et al., 2002; Barua et al., 2003; Fennessy et al., 2003)

\subsection{2 eNOS expression and NO production}

Low concentrations of extracts of cigarette smoke contract isolated porcine coronary 
arteries by superoxide anion-mediated degradation of NO, while higher concentrations induce a cyclooxygenase-mediated vasodilation (Moruhara et al., 1994; Holden et al, 1990). In human saphenous veins taken from cigarette smokers, endothelium-dependent relaxation is inhibited due to a reduction in activity of eNOS related to an inadequate supply of the coenzyme tetrahydrobiopterin (Higman et al., 1996). Cigarette smoke decreases cGMP production in cultured endothelial cells (Nagy et al., 1997).

There are conflicting reports on the effects of acute smoking in the cerebral circulation. Smoking a single cigarette caused a biphasic effect on cerebrovascular tone: constriction of pial arterioles at 30 seconds, followed by dilation 5-10 minutes later. The vasodilation was likely due to a combination of nicotine-mediated sympathetic activation, NO production, and $\mathrm{K}^{+}$channel activation, while the constrictor response was partially due to thromboxane A 2 release since the response was attenuated by seratrodast, a thromboxane A2 receptor antagonist (Iida et al., 1998).

The immunohistochemical expression of eNOS (in pulmonary arterial endothelium) and eNOS protein content (in lung tissue) is lower in smokers (Barbera et al., 2001). In humans, the post partum placenta of smokers has lower eNOS protein levels (Wang et al., 2000). Incubation of pulmonary artery endothelial cells with cigarette smoke extracts decreases eNOS mRNA, protein, and eNOS activity (Su et al., 1998). Thus, cigarette smoking is associated with reduced expression of eNOS, protein content and eNOS activity in arteries and this diminished synthesis of NO contributes to the alterations in the structure and endothelial function of blood vessels. In mice exposed to the long-term (16 
weeks) effects of cigarette smoke, there is a reduction of eNOS protein expression in the femoral and carotid arteries (Guo et al., 2006).

There are also discrepant findings related to eNOS expression changes due to cigarette smoking, where rats exposed to cigarette smoke showed increased eNOS mRNA (after 2 days) and protein (after 7 days) in the whole lung (Wright et al., 1999). Likewise, in a study of healthy smokers, there is reduced endothelium-dependent vasodilation, NO generation, and eNOS activity in spite of increased eNOS protein expression (Barua et al., 2001).

Cigarette smoking also has additional effects on vascular excitation-contraction coupling. Cigarette smoking causes an upregulation of voltage-gated $\mathrm{Ca}^{2+}$ channels and a downregulation of $\mathrm{Ca}^{2+}$-activated $\mathrm{K}^{+}(\mathrm{BK})$ channels in rat cerebral arteries, effects that will attenuate NO-mediated dilation (Gerzanich et al., 2001). In canine basilar arteries nicotine potentiates contractile response through PKC activation (Koide et al., 2005).

\subsubsection{Smoking and development of atherosclerosis}

Cigarette smoking promotes the initiation and progression of atherosclerosis by inhibiting vasodilation, increasing vasoconstriction, stabilizing thrombus, initiating inflammation, and modifying lipid profiles. Cigarette smoking increases superoxide $\left(\mathrm{O}_{2}{ }^{-}\right)$production (Raij et al., 2001; Barua et al., 2003) and $\mathrm{O}_{2}{ }^{-}$inactivates the primary vasodilator nitric

oxide (NO) (Wei et al, 1985; Rubanyi et al., 1986), thereby producing endothelial 
dysfunction by reducing NO bioavailability. Levels of superoxides are increased in atherosclerotic vessels (Miller et al., 1998; Hathaway et al., 2002) and inactivation of NO by superoxide plays a key role in endothelial dysfunction of atherosclerotic arteries (Heistad, 2006).

Increased vasoconstriction is another risk factor for atherosclerosis. Increased endothelin production induced by cigarette smoking (Haak et al., 1994; Rahman et al., 2006) leads to vasoconstriction, thereby helping initiation and progression of atherosclerosis.

Cigarette smoking helps in stabilization of thrombin at the site of arterial injury. In normal arteries, activated protein $\mathrm{C}$ (APC) is a potent anticoagulant (Esmon and Owen, 1981; Dahlback et al., 2005) which inhibits propagation of thrombus to the arterioles. Cigarette smoking decreases activated protein C levels (Farnandez et al., 2002), thereby allowing propagation of thrombus and thus helping initiation and formation of atherosclerosis down the artery.

Cigarette smoking promotes atherosclerosis by affecting the lipid profile of smokers. Smokers have higher serum cholesterol, triglyceride and LDL levels but lower HDL levels (Sinha et al., 1995; Craig et al., 1989). Cigarette smoke stimulates the release of catecholamine by the adrenal cortex (Andersson et al., 1993), leading to the increased serum concentrations of free fatty acid (FFA) observed in smokers; FFA is a well-known stimulant of hepatic secretion of VLDL and hence triglycereide; and HDL vary inversely with VLDL concentrations in serum (Craig et al., 1989). Cigarette smoking also increases 
oxidative modification of plasma LDL (Frei et al., 1991). Circulatory products of lipid peroxidation and autoantibody titers to oxidized LDL (ox-LDL) are significantly increased in smokers (Heitzer et al., 1996). This is why ox-LDL is considered as an antigen for atherosclerosis development (Hansson et al., 1996).

The inflammatory response is an essential component in the initiation and propagation of atherosclerosis. Levels of multiple inflammatory markers including C-reactive protein, interleukin-6, and tumor necrosis factor alpha are increased in cigarette smokers (Tracy et al, 1997; Bermudez et al., 2002; Mendall et al., 1997). Proinflammatory cytokines, e.g., VCAM-1, ICAM-1, E-selectin levels are also increased in cigarette smokers indicating increased leukocyte-endothelial cell interaction producing inflammation (Bermudez et al., 2002; Mazzone et al., 2001). Genetic predisposition has also been found to influence the initiation and progression of atherosclerosis in smokers (Wang et al., 2000; Wang et al., 2002).

\subsubsection{Smoking and matrix metalloproteinases (MMPs)}

Matrix metalloproteinases (MMPs) are zinc-dependent endopeptidases, which are capable of degrading many extracellular matrix proteins, but they are also capable of processing a number of bioactive molecules. The MMPs play an important role in tissue remodeling associated with various physiological and pathological processes such as morphogenesis, angiogenesis, tissue repair etc. MMP activity is correlated with vascular smooth muscle cell migration and proliferation after vascular injury (Bendeck et al.; 1994; Zempo et al., 
1994; Southgate et al., 1996) and inhibition of MMP activity suppresses VSMC proliferation (Bendeck et al., 1994; Zempo et al., 1996). Leukocytes, endothelial cells and VSMCs are the principal sources of MMPs in the vasculature (Chase et al., 2003) and cigarette smoking may activate these vascular sources of MMPs by increasing vascular reactive oxygen species (ROS) and vascular inflammation (Perlstein and Lee, 2006).

Excessive extracellular matrix breakdown is a major determinant of aortic expansion and aneurysm formation (Shah, 1997) and there is much evidence supporting a strong association between cigarette smoking and development of aneurysms (MacSweeney et al., 1994; Alcorn et al., 1996; Chang et al. 1997; Lee et al., 1997; Brown et al., 1999; Vardulaki et al., 2000; Lindholt et al. 2001). The association of smoking with aneurismal subarachnoid hemorrhage also involves MMPs such as MMP-9 which is markedly increased in intracranial aneurysm (Kim et al., 1997). Cigarette smoke induces chronic inflammation and the increased local production of MMPs results in pulmonary emphysema (Shapiro, 1995; Shapiro, 2000; Shapiro, 2002) and aortic aneurysms in smokers (Koch et al., 1990; Thompson et al., 1996) through the degradation of the extracellular matrix, accelerated destructive remodeling of elastin, collagen and other structural proteins (Buckley et al., 2004).

The effects of cigarette smoking as a source of ROS and the associated decreases in NO level in smokers' vasculature have been described above. Increased ROS (Galis et al., 1998) and decreased NO (Chen et al., 2004) induce MMP transcription, thus establishing a central role of cigarette smoking in MMP transcription. ROS activates the latent pro- 
forms of MMPs (Rajagopalan et al., 1996) and NO inhibits MMP activation (Phillips et al., 2004). Moreover, plasmin activates MMPs, and smoking is associated with increased plasminogen activator levels (Lindholt et al., 2003). On the contrary, it has also been counter-intuitively reported that ROS induces tissue inhibitor of MMPs activity (Li et al., 2004). Thus the role of MMP in smoking-related vascular disease is complex and still not clear. Additional data on the role of MMPs and vascular damage may provide important clues to the therapeutic approach for vascular disease among smokers.

\subsubsection{Smoking and cell signaling pathways}

The gaseous components of cigarette smoke destroy or inactivate the thiol-containing guanylate cyclase in endothelial cells, making it possible that externally added thiols (e.g., glutathione, GSH etc.) may be able to protect endothelial cells by binding to unknown components of cigarette smoke (Nagy et al., 1997). Cigarette smoke and its formaldehyde components are able to attenuate the release of NO by reducing receptor-activated increases in endothelial $\mathrm{Ca}^{2+}$ (Mazak et al., 2002).

\subsubsection{Smoking and Apoptosis}

Cigarette smoke activates caspase-3 to induce apoptosis of human umbilical vein endothelial cells (Wang et al., 2001). Stimulation of c-jun n-terminal kinase (JNK), or stress-activated protein kinase, is important in the cellular response to environmental 
stress and pro-inflammatory cytokines. The JNK pathway is activated when cells are exposed to noxious stimuli, and is also involved in cell differentiation and apoptosis (Kuo et al, 2005). Consistent with this is the observation that cigarette smoke-induced apoptosis of vascular endothelial cells occurs through the JNK pathway that is activated, at least partially, by oxidative stress. Cigarette smoke-induced activation of JNK phosphorylation and endothelial cell injuries are both inhibited by superoxide dismutase and catalase (Hoshino et al., 2005).

\subsubsection{Smoking, gene modulation and vascular immune modulation}

Treatment of human primary arterial endothelial cells with nicotine at concentrations similar to those in the blood of smokers results in increased mRNA levels of eNOS, angiotensin-1 converting enzyme, tissue type plasminogen activator, plasminogen activator inhibitor-1, von Willebrand factor, and vascular cell adhesion molecule-1. Thus nicotine alters the expression of a number of endothelial genes whose products play major roles in regulating vascular tone and thrombogenecity (Zhang et al., 2001).

Cigarette smoking dysregulates a number of endothelial genes, some with known or potential relevance to vasoregulation, including soluble epoxide hydrolase or epoxide hydrolase-2 (Epxh2), complement factor $\mathrm{H}(\mathrm{Cfh})$ or adrenomedullin binding protein-1, and calcitonin receptor-like (Calcrl). Epxh2 catalyzes the hydrolysis of the endothelialderived hyperpolarizing factor epoxyeicosatrienoic acid (Imig et al., 2002). Cfh binds to the vasodilator adrenomedullin and modulates its effects (Zhou et al., 2002), and Calcrl is 
part of the receptor complex for adrenomedullin and calcitonin gene-related peptide (Hay et al., 2002). Endothelial cells collected from tobacco smoke-exposed mouse aortas show a more than three-fold upregulation of complement factor $\mathrm{H}$, calcitonin receptor-like, and soluble epoxide hydrolase; thus these changes may contribute to the hypertensive response during cigarette smoking (Maresh et al., 2005). In apoE deficient mice that have been fed a Western diet and exposed to cigarette smoke for 5 weeks, carotid artery cuffing produced increased intimal thickening (Tani et al, 2004). Immune modulation by cigarette smoke, as characterized by aberrant antibody responses to oxidized LDL and reduced lymphotoxin $\beta$ mRNA expression, was associated with increased intimal thickening (Tani et al., 2004).

\subsubsection{Smoking, tissue factors and cell injury}

Effective endogenous fibrinolysis requires rapid release of tissue plasminogen activator (tPA) from the vascular endothelium. Cigarette smoking inhibits tPA release in human smokers, thus increasing the risk of atherothrombosis in smokers through a reduction in fibrinolytic capacity (Newby et al., 1999). Chronic exposure to cigarette smoke both in apoE deficient mice and human subjects increases tissue factor (TF) expression and thrombogenecity, representing additional mechanisms for the increased risk of atherothrombotic events in smokers (Matetzky et al., 2000). Long-term exposure to cigarette smoke leads to increased experimental aneurismal dilatation of mouse abdominal aorta, possibly caused by smoking-induced inhibition of connective tissue 
repair processes within the aortic wall (Buckley et al., 2004).

\subsection{Hypothesis and specific objectives}

Based on the above-mentioned evidence, the central hypothesis of my thesis work is that increased endothelin (ET-1) and decreased NO bioavailability contribute to increased vascular contractility in cigarette smoking rats.

The following objectives are addressed experimentally:

-To examine the effect of smoking on vascular contractility.

-To evaluate basal NO levels.

-To examine stimulated NO production.

-To determine the effect of smoking on liver enzyme gene expression (CYP 1A1, 1A2).

-To measure plasma ET-1 levels.

-To evaluate the effect of smoking on body weight. 


\subsection{Tables}

Table 1. 1 Cigarette smoke-induced structural alterations in the vasculature.

\begin{tabular}{|c|c|c|c|c|}
\hline Blood vessel & Structural alteration & Species & Mode of exposure & Reference \\
\hline \multicolumn{5}{|c|}{ Active smoking: } \\
\hline Aorta & Aneurysm & Human & Chronic Smoking & Lee et al., 1997 \\
\hline Aorta & $\downarrow$ Elastic properties & Human & Chronic Smoking & $\begin{array}{l}\text { Stefanadis et al., } \\
1998\end{array}$ \\
\hline Aorta & Aneurysm & Mouse & Chronic Smoking & Buckley et al., 2004 \\
\hline Aorta root & $\uparrow$ atherosclerotic plaques & Mouse & Chronic Smoking & $\begin{array}{l}\text { Matetzky et al., } \\
2000\end{array}$ \\
\hline Brachial a. & $\uparrow \mathrm{IMT}$ & Human & Chronic Smoking & Esen et al., 2004 \\
\hline Carotid a. & $\uparrow \mathrm{IMT}$ & Human & Chronic Smoking & Poredos et al., 1999 \\
\hline Carotid a. & $\uparrow$ atherosclerotic plaques & Human & Chronic Smoking & $\begin{array}{l}\text { Matetzky et al., } \\
2000\end{array}$ \\
\hline Carotid a. & $\uparrow$ wall thickening & Human & Chronic Smoking & $\begin{array}{l}\text { van den Berkmortel } \\
\text { et al., } 2000\end{array}$ \\
\hline Carotid a. & Intimal hyperplasia & Rat & Chronic Smoking & Petric et al., 1995 \\
\hline Carotid a. & $\uparrow$ intimal thickening & Mouse & Chronic Smoking & Tani et al., 2004 \\
\hline Cerebral a. & $\begin{array}{l}\text { Swollen and loose } \\
\text { endothelium }\end{array}$ & Human & Acute smoking & Zhang et al., 2006 \\
\hline Coronary a. & $\uparrow$ wall thickening & Mouse & Chronic Smoking & Guo et al., 2006 \\
\hline Epicardial a. & $\begin{array}{l}\uparrow \text { wall thickening \& } \\
\text { atherosclerosis }\end{array}$ & Human & Chronic Smoking & Zeiher et al., 1995 \\
\hline Femoral a. & $\uparrow$ wall thickening & Human & Chronic Smoking & $\begin{array}{l}\text { van den Berkmortel } \\
\text { et al., } 2000\end{array}$ \\
\hline Mesenteric a. & Swollen endothelium & Rat & Acute smoking & Zhang et al., 2006 \\
\hline Pulmonary a. & $\uparrow$ wall thickening & Rat & Chronic Smoking & He et al., 1991 \\
\hline Pulmonary al. & $\uparrow$ muscularizaation & Guineapig & Chronic Smoking & Wright et al., 1991 \\
\hline Saphenous v. & Thickened endothelium & Human & Chronic Smoking & Higman et al., 1994 \\
\hline \multicolumn{5}{|c|}{ Passive smoking: } \\
\hline Aorta & Atherosclerosis & Rabbit & Chronic Smoking & Zhu et al., 1993 \\
\hline Aorta & Atherosclerosis & Rabbit & Chronic Smoking & Sun et al., 1994 \\
\hline
\end{tabular}




\begin{tabular}{|c|c|c|c|c|}
\hline Blood vessel & Structural alteration & Species & Mode of exposure & Reference \\
\hline Aorta & $\begin{array}{l}\text { Deterioration of elastic } \\
\text { properties }\end{array}$ & Human & Chronic Smoking & $\begin{array}{l}\text { Stefanadis et al., } \\
1998\end{array}$ \\
\hline Aorta & Atherosclerotic plaques & Cockerel & Chronic Smoking & Penn et al., 1993 \\
\hline Brachial a. & Endothelial cell damage & Human & Chronic Smoking & $\begin{array}{l}\text { Celermajer et al., } \\
1996\end{array}$ \\
\hline Carotid a. & $\uparrow$ IMT & Human & Chronic Smoking & Howard et al., 1998 \\
\hline Pulmonary a. & Atherosclerosis & Rabbit & Chronic Smoking & Zhu et al., 1993 \\
\hline Pulmonary a. & Atherosclerosis & Rabbit & Chronic Smoking & Sun et al., 1994 \\
\hline
\end{tabular}

IMT $=$ intima-media thickness, al. = arteriole, a. $=$ artery, $\mathrm{v} .=$ vein, $\uparrow=$ increased, $\downarrow=$ damage. 
Table 1. 2 Cigarette smoke-induced impairment of endothelium-dependent vasodilation.

\begin{tabular}{|c|c|c|c|}
\hline Vessel & Exposure & Species & Reference \\
\hline \multicolumn{4}{|c|}{ Active smoking: } \\
\hline Aorta & Chronic smoking & Rat & Jorge et al., 1995 \\
\hline Aorta & Acute smoking & Rat & Raij et al., 2001 \\
\hline Aorta & Acute smoking & Rabbit & Ota et al., 1997 \\
\hline Brachial a. & Acute smoking & Human & Lekakis et al., 1995 \\
\hline Brachial a. & Chronic smoking & Human & Tanriverdi et al., 2006 \\
\hline Brachial a. & Chronic smoking & Human & McVeigh et al, 1996 \\
\hline Brachial a. & Acute smoking & Human & Lekakis et al., 1997 \\
\hline Brachial a. & Acute smoking & Human & Sarabi and Lind, 2000 \\
\hline Brachial a. & Acute nicotine & Human & Sarabi and Lind, 2000 \\
\hline Cerebral a. & Acute smoking & Rat & Iida et al., 2006 \\
\hline Dorsal hand v. & Acute nicotine & Human & Chalon et al., 2000 \\
\hline Dorsal hand v. & Acute nicotine & Human & Sabha et al., 2000 \\
\hline Epicardial a. & Chronic smoking & Human & Zeiher et al., 1995 \\
\hline Femoral a. & Chronic smoking & Rabbit & Freischlag et al., 1999 \\
\hline Cerebral a & Acute smoking & Human & Zhang et al., 2006 \\
\hline Mesenteric a. & Acute smoking & Rat & Zhang et al., 2006 \\
\hline Saphenous v. & Chronic smoking & Human & Higman et al., 1996 \\
\hline \multicolumn{4}{|c|}{ Passive smoking: } \\
\hline Aorta & Chronic smoking & Rat & Hutchison et al., 1998 \\
\hline Aorta & Chronic smoking & Rabbit & Torok et al., 2000 \\
\hline Brachial a. & Chronic smoking & Human & Celermajer et al., 1996 \\
\hline Coronary a. & Chronic smoking & Human & Sumida et al., 1998 \\
\hline Coronary a. & Chronic smoking & Human & Otsuka et al., 2001 \\
\hline
\end{tabular}




\subsection{Figures}

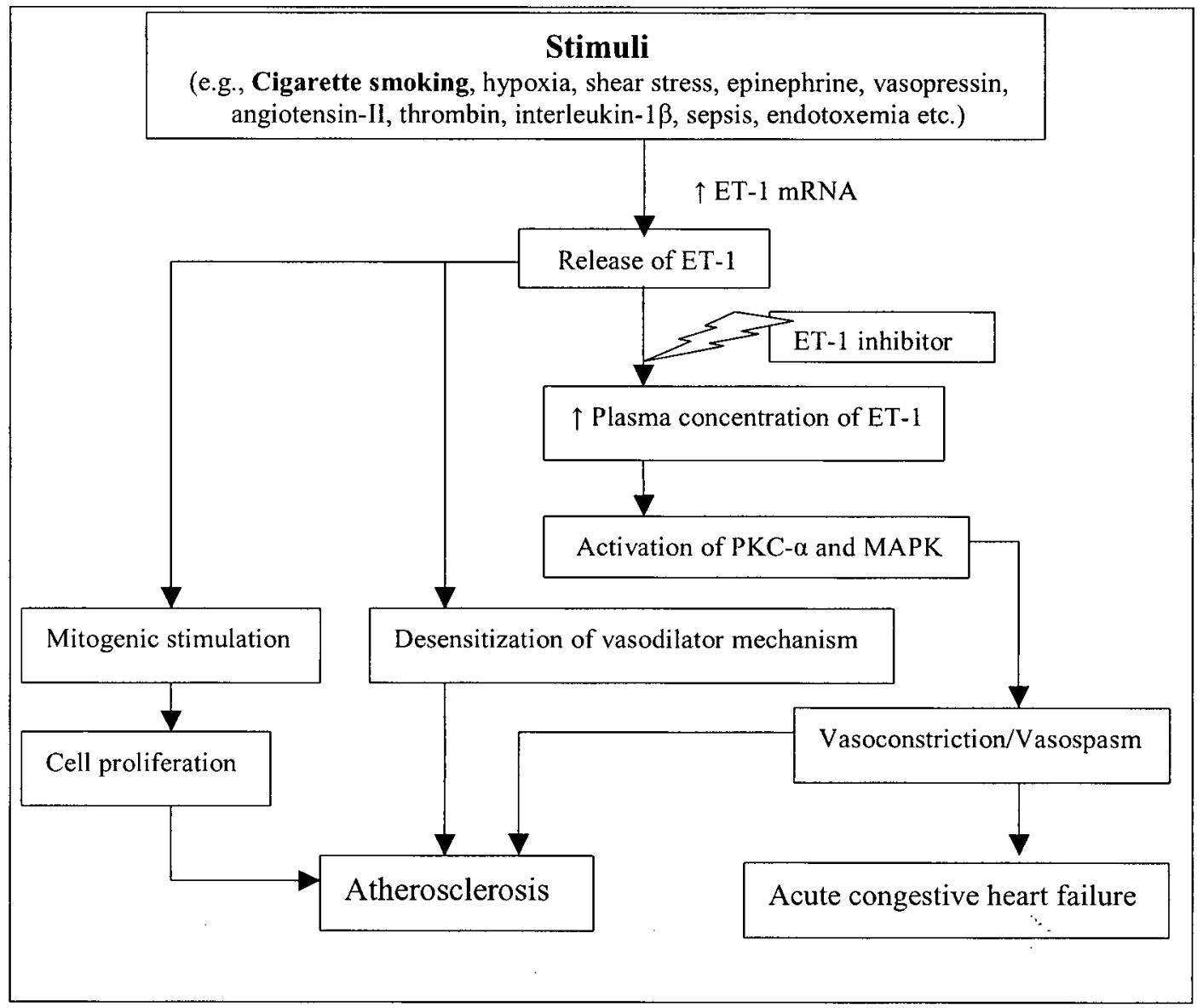

Figure 1.1 Smoking induced release of endothelin (ET-1) activates a number of events that leads to dysfunction of the cardiovascular system. 


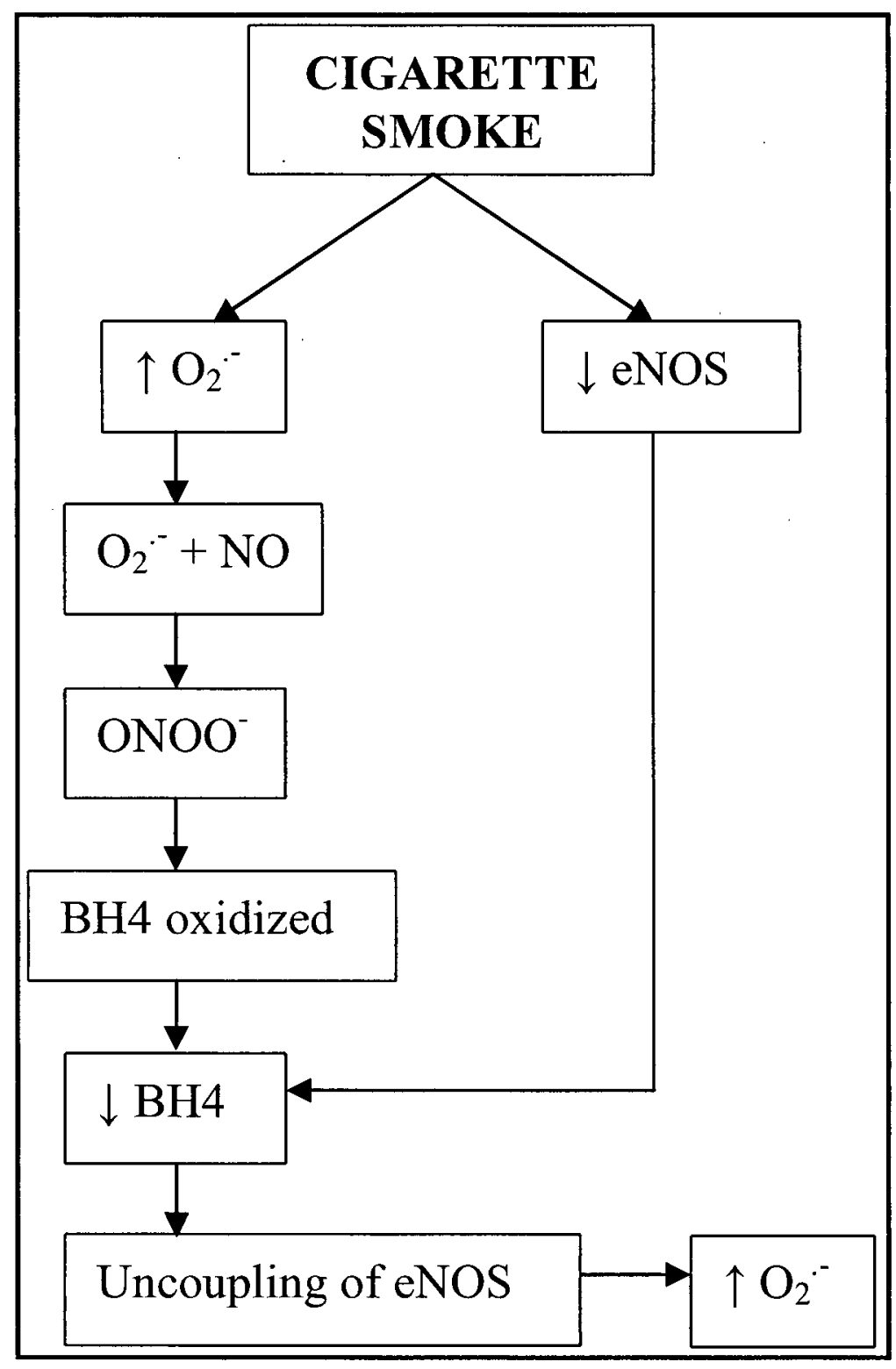

Figure 1. 2 Uncoupling of eNOS leads to increased oxidative stress. eNOS= endothelial nitric oxide synthase, ONOO- $=$ Peroxinitrite, $\mathrm{NO}=$ nitric oxide, $\mathrm{O} 2 .-=$ superoxide anion, $\uparrow=$ increase/ upregulation, $\downarrow=$ decrease/downregulation, $\mathrm{BH} 4=$ tetrahydrobiopterin. 


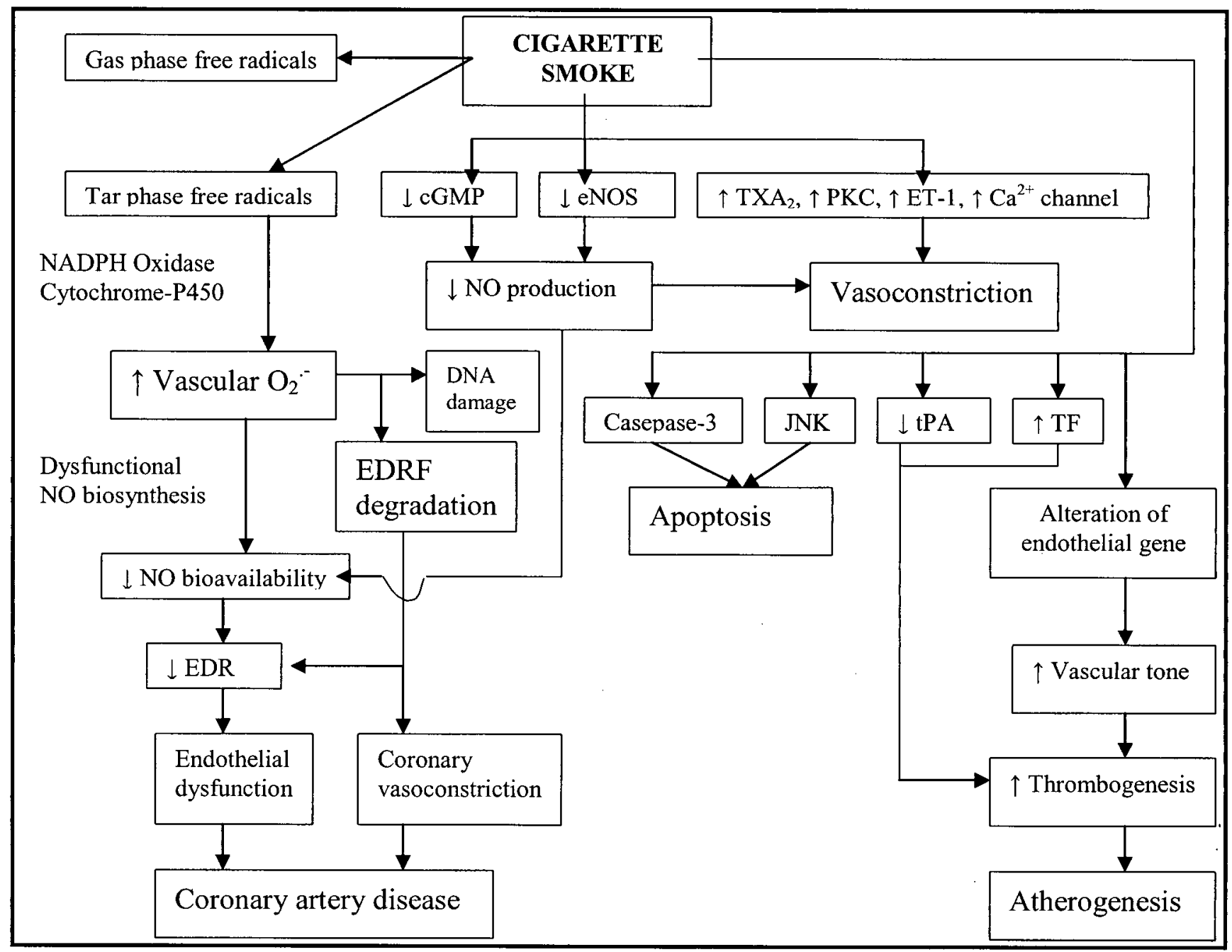

Figure 1. 3 Possible mechanisms of cigarette smoke-induced vasculopathy. cGMP $=$ cyclic guanosin monophosphate, $\mathrm{eNOS}=$ endothelial nitric oxide synthase, $\mathrm{TXA}_{2}=$ thromboxane $\mathrm{A}_{2}, \mathrm{PKC}=$ protein kinase $\mathrm{C}, \mathrm{ET}-1=$ endothelin-1, $\mathrm{NO}=$ nitric oxide, $\mathrm{O}_{2}{ }^{-}=$superoxide anion, $\mathrm{JNK}=\mathrm{c}$-Jun $\mathrm{N}$-terminal Kinase, $\mathrm{tPA}=$ tissue plasminogern activator, $\mathrm{TF}=$ tissue factor, $\mathrm{EDRF}=$ endothelial derived relaxing factor, $\mathrm{EDR}=$ endothelial derived relaxation, $\uparrow=$ increase/upregulation, $\downarrow=$ decrease/downregulation. 


\subsection{References}

Adachi, C., Naruse, M., Ishihara, Y., Tanabe, A., Takagi, S., Yoshimoto, T., Naruse, K., Kagawa, J., Takano, K., 2000. Effects of acute and chronic cigarette smoking on the expression of endothelin-1 mRNA of the cardiovascular tissues in rats. J Cardiovasc Pharmacol. 36, S198-S200.

Ahmadzadehfar, H., Oguogho, A., Efthimiou, Y., Kritz, H., Sinzinger, H., 2006. Passive cigarette smoking increases isoprostane formation. Life Sci. 78, 894-897.

Alcorn, H.G., Wolfson, S.K. Jr, Sutton-Tyrrell, K., 1996. Risk factors. for abdominal aortic aneurysms in older adults enrolled in The Cardiovascular Health Study. Arterioscler. Thromb. Vasc. Biol. 16, 963-970.

Andersson, K., Eneroth, P., Arner, P., 1993. Changes in circulating lipid and carbohydrate metabolites following systemic nicotine treatment in healthy men, Int. J. Obes. Relat. Metab. Disord. 17, 675-680.

Anggard, E., 1994. Nitric oxide: mediator, murderer, and medicine. Lancet 343, 11991206.

Anton, M.M., Cortez-Cooper, M.Y., DeVan, A.E., Neidre, D.B., Cook, J.N., Tanaka, H., 2006. Cigarette smoking, regular exercise, and peripheral blood flow. Atherosclerosis $185,201-205$.

Arai, H., Hori, S., Aramori, I., Ohkubo, H., Nakanishi, S., 1990. Cloning and expression of a cDNA encoding an endothelin receptor. Nature 348,730-732.

Arosino, E., De Marchi, S., Rigoni, A., Prior, M., Lechi, A., 2006. Effects of smoking on cardiopulmonary baroreceptor activation and peripheral vascular resistance. Eur J. Clin. Invest. 36, 320-325.

Barbera, J.A., Peinado, V.I., Santos, S., Ramirez, J., Roca, J., Rodriguez-Roisin, R., 2001. Reduced expression of endothelial nitric oxide synthase in pulmonary arteries of smokers. Am. J. Respir. Crit. Care. Med. 164, 709-713.

Barua, R.S., Ambrose, J.A., Eales-Reynolds, L.J., DeVoe, M.C., Zervas, J.G., Saha, D.C., 2002. Heavy and light cigarette smokers have similar dysfunction of endothelial vasoregulatory activity: An in vivo and in vitro correlation. J. Am. Coll. Cardiol. 39 , 1758-1763.

Barua, R.S., Ambrose, J.A., Eales-Reynolds, L.J., DeVoe, M.C., Zervas, J.G., Saha, D.C., 2001. Dysfunctional endothelial nitric oxide biosynthesis in healthy smokers with impaired endothelium-dependent vasodilatation. Circulation 104,1905-1910. 
Bendeck, M.P., Zempo, N., Clowes, A.W., Galardy, R.E., Reidy, M.A., 1994. Smooth muscle cell migration and matrix metalloproteinase expression after arterial injury in the rat. Circ. Res. 75, 539-545.

Bermudez, E.A., Rifai, N., Buring, J.E., Manson, J.E., Ridker, P.M., 2002. Relation between markers of systemic vascular inflammation and smoking in women. Am. J. Cardiol. 89 , 1117-1119.

Borrisova, A.M., Tankova, T., Kirilov, G., Dakovska, L., Krivoshiev, S., 2004. The effect of smoking on peripheral insulin sensitivity and plasma endothelin level. Diabetes Metab. 30, 147-152.

Brown, L.C., Powell, J.T., 1999. Risk factors for aneurysm rupture in patients kept under ultrasound surveillance. UK Small Aneurysm Trial Participants. Ann. Surg. 230, 289296.

Buckley, C., Wyble, C.W., Borhani, M., Ennis, T.L., Koayashi, D.K., Curci, J.A., Shapiro, S.D., Thompson, R.W., 2004. Accelerated enlargement of experimental abdominal aortic aneurysms in a mouse model of chronic cigarette smoke exposure. $199,896-903$.

Campisi, R., Czermin, J., Schoder, H., Sayre, J.W., Marengo, F.D., Phelps, M.E., Schelbert, H.R., 1998. Effects of long-term smoking on myocardial blood flow, coronary vasomotion, and vasodilator capacity. Circulation 98, 119-125.

Celermajer, D.S., Adams, M.R., Clarkson, P., Robinson, J., McCredie, R., Donald, A., Deanfield, J.E., 1996. Passive smoking and impaired endothelium-dependent arterial dilatation in healthy young adults. N. Engl. J. Med. 334, 150-154.

Chalon, S., Moreno, H. Jr, Benowitz, N.L., Hoffman, B.B., Blaschke, T.F., 2000. Nicotine impairs endothelium-dependent dilatation in human veins in vivo. Clin Pharmacol. Ther. 67, 391-397.

Chang, J.B., Stein, T.A., Liu, J.P., Dunn, M.E., 1997. Risk factors associated with rapid growth of small abdominal aortic aneurysms. Surgery 121, 117-122.

Chase, A.J., Newby, A.C., 2003. Regulation of matrix metalloproteinase (matrixin) genes in blood vessels: a multi-step recruitment model for pathological remodelling. J. Vasc. Res. 40, 329-343.

Chen, H.H., Wang, D.L., 2004. Nitric oxide inhibits matrix metalloproteinase-2 expression via the induction of activating transcription factor 3 in endothelial cells. Mol. Pharmacol. 65,1130-1140. 
Chen, H.W., Chien, M.L., Chaung, Y.H., Lii, C.K., Wang, T.S., 2004. Extracts from cigarette smoke induce DNA damage and cell adhesion molecule expression through different pathways. Chem. Biol. Interact. 150, 233-241.

Cohen, R.A., Zitnay, K.M., Haudenschild, C.L., Cunningham, L.D., 1988. Loss of selective endothelial cell vasoactive function caused by hypercholesterolemia in pig coronary arteries. Circ. Res. 63, 903-910.

Craig, W.Y., Palomaki, G.E., Haddow, J.E., 1989. Cigarette smoking and serum lipid and lipoprotein concentrations: An analysis of published data. BMJ 298 , 784-788.

Czekaj, P., Wiaderkiewicz, A., Florek, E. Wiaderkiewicz, R., 2005. Tobacco smokedependent changes in cytochrome $\mathrm{P} 4501 \mathrm{~A} 1,1 \mathrm{~A} 2$, and $2 \mathrm{E} 1$ protein expressions in fetuses, newborns, pregnant rats, and human placenta, Arch. Toxicol. 79 , 13-24.

Dahlbäck, B., Villoutreix, B.O., 2005. Regulation of blood coagulation by the protein C anticoagulant pathway: Novel insights into structure-function relations and molecular recognition. Arterioscler. Thromb. Vasc. Biol. 25, 1311-1320.

de Nucci, G., Thomas, R., 1988. D'Orleans-Juste, P., Antunes, E., Walder, C., Warner, T.D., Vane, J.R., Pressor effects of circulating endothelin are limited by its removal in the pulmonary circulation and by the release of prostacyclin and endotheliumderived relaxing factor. Proc. Natl. Acad. Sci. U.S.A. 85, 9797-9800.

Douglas, S.A., Beck, G.R. Jr, Elliott, J.D., Ohlstein, E.H., 1995. Pharmacological evidence for the presence of three distinct functional endothelin receptor subtypes in the rabbit lateral saphenous vein. Br. J. Pharmacol. 114, 1529-1540.

Doutreleau, S., Piquard, F., Lonsdorfer, E., Rouyer, O., Lampert, E., Mettauer, B., Richard, R., Geny, B., 2004. Improving exercise capacity, 6 wk training tends to reduce circulating endothelin after heart transplantation. Clin Transplasnt. 18,672-675.

Esen, A.M., Barutcu, I., Acar, M., Degirmenci, B., Kaya, D., Turkmen, M., Melek, M., Onrat, E., Esen, O.B., Kirma, C., 2004. Effect of smoking on endothelial function and wall thickness of brachial artery. Circ. J. 68, 1123-1126.

Esmon, C.T., Owen, W.G., 1981. Identification of an endothelial cell cofactor for thrombin-catalyzed activation of protein C. Proc. Natl. Acad. Sci. U. S. A. 78, 22492252 .

Failla, M., Grappiolo, A., Carugo, S., Calchera, I., Giannattasio, C., Mancia, G., 1997. Effects of cigarette smoking on carotid and radial artery distensibility. J. Hypertens. $15,1659-1664$. 
Fang, Q., Zhao, M., Ren, G., 1997. Effects of cigarette smoke on proliferation and ET-1 release of airway smooth muscle cells. Zhonghua. Yi. Zue. Za. Zhi. 77, 201-204.

Fennessy, F.M., Moneley, D.S., Wang, J.H., Kelly, C.J., Bouchier-Hayes, D.J., 2003. Taurine and vitamin $\mathrm{C}$ modify monocyte and endothelial dysfunction in young smokers. Circulation 107, 410-415.

Fernández, J.A., Gruber, A., Heeb, M.J., Griffin, J.H., 2002. Protein C Pathway Impairment in Nonsymptomatic Cigarette Smokers. Blood Cells, Molecules, and Diseases 29, 73-82.

Fiers, W., Beyaert, R., Declercq, W., Vandenabeele, P., 1999. More than one way to die: apoptosis, necrosis and reactive oxygen damage. Oncogene 18, 7719-7730.

Frei, B., Forte, T.M., Ames, B.N., Cross, C.E., 1991. Gas phase oxidants of cigarette smoke induce lipid peroxidation and changes in lipoprotein properties in human blood plasma: Protective effects of ascorbic acid. Biochem. J. 277, 133-138.

Freischlag, J.A., Johnson, D., Farooq, M.M., Doty, J., Cambria, R.A., Seabrook, G.R., Towne, J.B., 1999. Cigarette smoke impairs endothelium-dependent relaxation in rabbit superficial femoral veins. J. Surg. Res. 81, 77-80.

Galis, Z.S., Asanuma, K., Godin, D., Meng, X., 1998. N-acetyl-cysteine decreases the matrix-degrading capacity of macrophage-derived foam cells: new target for antioxidant therapy? Circulation 97, 2445-2453.

Gerzanich, V., Zhang, F., West, G.A., Simard, J.M., 2001. Chronic nicotine alters NO signaling of $\mathrm{Ca} 2+$ channels in cerebral arterioles. Circ. Res. 88, 359-365.

Giannattasio, C., Mangoni, A.A., Stella, M.L., Carugo, S., Grassi, G., Mancia, G., 1994. Acute effects of smoking on radial artery compliance in humans. J. Hypertens. 12, 691-696.

Glantz, S.A., Parmley, W.W., 1991. Passive smoking and heart disease: epidemiology, physiology, and biochemistry. Circulation. 83, 1-12.

Glantz, S.A., Parmley, W.W., 1995. Passive smoking and heart disease: mechanisms and risk. JAMA 273, 1047-1053.

Goerre, S., Staehli, C., Shaw, S., Luscher, T.F., 1995. Effect of cigarette smoking and nicotine on plasma endothelin-1 levels. J. Cardiovasc. Pharmacol. 26, S236-238.

Granström, B.W., Xu, C.B., Nilsson, E., Vikman, P., Edvinsson, L., 2006. Smoking particles enhance endothelin $\mathrm{A}$ and endothelin $\mathrm{B}$ receptor-mediated contractions by enhancing translation in rat bronchi. BMC Pulm. Med. 15; 6:6. 
Guo, X., Oldham, M.J., Kleinman, M., Phalen, R.F., Kassab, G.S., 2006. Effect of Cigarette Smoking on Nitric Oxide, Structural and Mechanical Properties of Mouse Arteries. Am. J. Physiol. Heart. Circ. Physiol. [Epub ahead of print] (In Press).

Haak, T., Marz, W., Jungmann, E., Hausser, S., Siekmeier, R., Gross, W., Usadel, K.H., 1994a. Elevateed endothelin levels in patients with hyperlipoproteinemia. Clin. Invest. $72,580-584$.

Haak, T., Jungmann, E., Raab, C., Usadel, K.H., 1994. Elevated endothelin-1 levels after cigarette smoking. Metabolism 43, 267-269.

Hansson, G.K., 1996. Immune responses in atherosclerosis. In: Hansson, G.K., Libby, P., eds. Immune Functions of the Vessel Wall. Amsterdam, Netherlands: Harwood Academic Publishers; 1996. 159-172.

Hashimoto, T., Yoneda, M., Shimada, T., Kurosawa, M., Terano, A., 2004. Intraportal nicotine infusion in rats decreases hepatic blood flow through endothelin-1 and both endothelin A and endothelin B receptors. Toxicol. Appl. Pharmacol. 196, 1-10.

Hathaway, C., Heistad, D.D., Piegors, D.J., Miller, F.M., 2002. Regression of atherosclerosis in monkeys reduces vascular superoxide levels. Circ. Res. 90, 277283.

Hay, D.L., Smith, D.M., 2001. Adrenomedullin receptors: molecular identity and function. Peptides 22, 1753-1763.

Hayes, J.D., McLellan, L.I., 1999. Glutathione and glutathione-dependent enzymes represent a co-ordinately regulated defense against oxidative stress. Free Radic. Res. 31, 273-300.

He, J., Whelton, P.K., 1999. Passive cigarette smoking increases risk of coronary heart disease. Eur. Heart J. 20, 1764-1765.

He, J.F., 1991. Morphologic and morphometric studies of pulmonary artery endothelial abnormalities in rats induced by smoking. Zhonghua. Bing. Li. Xue. Za. Zhi. 20, 165168.

Heistad, D.D., 2006. Oxidative stress and vascular disease: 2005 Duff lecture. Arterioscler. Thromb. Vasc. Biol. 26, 689-695.

Heitzer, T., Brockhoff, C., Mayer, B., Warnholtz, A., Mollnau, H., Henne, S., Meinertz, T., Münzel, T., 2000. Tetrahydrobiopterin improves endothelium-dependent vasodilation in chronic smokers: evidence for a dysfunctional nitric oxide synthase. Circ. Res. 86, E36-E41. 
Heitzer, T., Just, H., Munzel, T., 1996. Antioxidant vitamin C improves endothelial dysfunction in chronic smokers. Circulation 94, 6-9.

Heitzer, T., Yla-Herttuala, S., Luoma, J., Kurz, S., Münzel, T., Just, H., Olschewski, M., Drexler, H., 1996. Cigarette smoking potentiates endothelial dysfunction of forearm resistance vessels in patients with hypercholesterolemia: Role of oxidized LDL. Circulation 9, 1346-1353.

Hickey, K.A., Rubanyi, G., Paul, R.J., Highsmith, R.F., 1985. Characterization of a coronary vasoconstrictor produced by cultured endothelial cells. Am. J. Physiol. 248 , C550-C556.

Higman, D.J., Powell, J.T., Greenhalgh, R.M., Coady, A., Moss J., 1994. Is thickening of the basal lamina in the saphenous vein a hallmark of smoking? Br. Heart J. 71, 45-50.

Higman, D.J., Strachan, A.M., Buttery, L., Hicks, R.C.J., Springall, D.R., Greenhalgh, R.M., Powell, J.T., 1996. Smoking impairs the activity of endothelial nitric oxide synthase in saphenous vein. Arterioscler. Thromb. Vasc. Biol. 16, 546-552.

Hirai, Y., Adachi, H., Fujiura, Y., Hiratsuka, A., Enomoto, M., Imaizumi, T., 2004. Plasma endothelin-1 level is related to renal function and smoking status but not to blood pressure: an epidemiological study. J. Hypertens. 22, 713-718.

Hirata, Y., Takagi, Y., Fukuda, Y., Marumo, F., 1989. Endothelin is a potent mitogen for rat vascular smooth muscle cells. Atherosclerosis 78, 225-228.

Holden, W.E., Kishiyama, S.S., Dong, S.P., Osborne, M.L., 1990. Endotheliumdependent effects of cigarette smoke components on tone of porcine intrapulmonary arteries in vitro. Toxicol. Appl. Pharmacol. 104, 191-199.

Hoshino, S., Yoshida, M., Inoue, K., Yano, Y., Yanagita, M., Mawatari, H., Yamane, H., Kijima, T., Kumagai, T., Osaki, T., Tachiba, I., Kawase, I., 2005. Cigarette smoke extract induces endothelial cell injury via JNK pathway. Biochem. Biophys. Res. Commun. 329, 58-63.

Howard, G., Wagenknecht, L.E., Burke, G.L., Diez-Roux, A., Evans, G.W., McGovern, P., Nieto, F.J., Tell, G.S., 1998. Cigarette smoking and progression of atherosclerosis: the Atherosclerosis Risk in Communities (ARIC) study. JAMA 279, 119-124.

Hutchison, S.J., Glantz, S.A., Zhu, B.Q., Sun, Y.P., Chou, T.M., Chatterjee, K., Deedwania, P.C., Parmley, W.W. and Sudhir, K., 1998. In-utero and neonatal exposure to secondhand smoke causes vascular dysfunction in newborn rats. J. Am. Coll. Cardiol. 32, 1463-1467. 
Iida H, Iida M, takenaka M, Fujiwara H, Dohi S. 2006. Angiotensin II type 1 (AT1)receptor blocker prevents impairment of endothelium-dependent cerebral vasodilation by acute cigarette smoking in rats. Life Sci. 78(12): 1310-1316.

Iida, M., Iida, H., Dohi, S., Takenaka, M., Fujiwara, H., 1998. Mechanisms underlying cerebrovascular effects of cigarette smoking in rats in vivo. Stroke 29, 1656-1665.

Imig, J.D., Zhao, X., Capdevila, J.H., Morisseau, C., Hammock, B.D., 2002. Soluble epoxide hydrolase inhibition lowers arterial blood pressure in angiotensin II hypertension. Hypertension 39, 690-694.

Jaimes, E.A., DeMaster, E.G., Tian, R.X., Raij, L., 2004. Stable compounds of cigarette smoke induce endothelial superoxide anion production via NADPH oxidase activation. Arterioscler. Thromb. Vasc. Biol. 24, 1031-1036.

Jorge, P.A., Ozaki, M.R., Almeida, E.A., 1995. Endothelial dysfunction in coronary vessels and thoracic aorta of rats exposed to cigarette smoke. Clin. Exp. Pharmacol. Physiol. 22, 410-413.

Kawachi, I., Colditz, G.A., Speizer, F.E., Manson, J.E., Stampfer, M.J., Willett, W.C., Hennekens, C.H., 1997. A prospective study of passive smoking and coronary heart disease. Circulation 95, 2374-2379.

Kim, J.W., Park, C.G., Hong, S.J., Park, S.M., Rha, S.W., Seo, H.S., Oh, D.J., Rho, Y.M., 2005. Acute and chronic effects of cigarette smoking on arterial stiffness. Blood Press. $14,80-85$.

Kim, S.C., Singh, M., Huang, J., Prestigiacomo, C.J., Winfree, C.J., Solomon, R.A., Connolly, E.S. Jr., 1997. Matrix metalloproteinase-9 in cerebral aneurysms. Neurosurgery. 41, 642-666.

Kiowski, W., Linder, L., Stoschitzky, K., Pfistener, M., Burckhardt, D., Burkart, F., Buhler, F.R., 1994. Diminished vascular response to inhibition of endotheliumderived nitric oxide and enhanced vasoconstriction to exogenously administered endothelin-1 in clinically healthy smokers. Circulation 90, 27-34.

Koch, A.E., Haines, G.K., Rizzo, R.J., 1990. Human abdominal aortic aneurysms immunophenotypic analysis suggesting an immune-mediated response. Am. J. Path. 137, 1199-1213.

Koide, M., Nishizawa, S., Yamamoto, S., Yamaguchi, M., Namba, H., Terakawa, S., 2005. Nicotine exposure, mimicked smoking, directly and indirectly enhanced protein kinase $\mathrm{C}$ activity in isolated canine basilar artery, resulting in enhancement of arterial contraction. J. Cereb. Blood Flow Metab. 25, 292-301. 
Kojda, G., Harrison, D., 1999. Interactions between NO and reactive oxygen species: Pathophysiological importance in atherosclerosis, hypertension, diabetes and heart failure. Cardiovasc. Res. 43, 562-571.

Kool, M.J., Hoeks, A.P., Struijker, Boudier, H.A., Reneman, R.S., Van Bortel, L.M.,1993. Short- and long-term effects of smoking on arterial wall properties in habitual smokers. J. Am. Coll. Cardiol. 22, 1881-1886.

Kritz, H., Schmid, P., Sinzinger, H., 1995. Passive smoking and cardiovascular risk. Arch Intern Med. 155, 942-1948

Kuklin, V., Kirov, M., Sovershaev, M., Andreasen, T., Ingebretsen, O.C., Ytrehus, K., Bjertnaes, L., 2005. Tezosentan-induced attenuation of lung injury in endotoxemic sheep is associated with reduced activation of protein kinase C. Crit. Care. 9, R211R217.

Kuo, W.H., Chen, J.H., Lin, H.H., Chen, B.C., Hsu, J.D., Wang, C.J. 2005. Induction of apoptosis in the lung tissue from rats exposed to cigarette smoke involves p38/JNK MAPK pathway. Chem. Biol. Interact. 155, 31-42.

Law, M.R., Morris, J.K., Wald, N.J., 1997. Environmental tobacco smoke exposure and ischaemic heart disease: an evaluation of the evidence. BMJ 315, 973-980.

Lee, A.J., Fowkes, F.G., Carson, M.N., Leng, G.C., Allan, P.L., 1997. Smoking, atherosclerosis and risk of abdominal aortic aneurysm. Eur. Heart J. 18, 671-676.

Lee, S.D., Lee, D.S., Chun, Y.G., Shim, T.S., Lim, C.M., Koh, Y., Kim, W.S., Kim, D.S., Kim, W.D., 2001. Cigarette smoke extract induces endothelin-1 via protein kinase C in pulmonary artery endothelial cells. Am. J. Physiol. Lung Cell Mol. Physiol. 281, L403-L411.

Lee, W.O., Wright, S.M., 1999. Production of endothelin by cultured human endothelial cells following exposure to nicotine or caffeine. Metabolism 48, 845-848.

Lee, A.J., Fowkes, F.G., Carson, M.N., 1997. Smoking, atherosclerosis and risk of abdominal aortic aneurysm. Eur. Heart J. 18, 671-676.

Lekakis, J., Papamichael, C., Vemmos, C., Nanas, J., Kontoyannis, D., Stamatelopoulos, S., Moulopoulos, S., 1997. Effect of acute cigarette smoking on endotheliumdependent brachial artery dilatation in healthy individuals. Am. J. Cardiol. 79, 529531.

Lekakis, J., Papamichael, C., Vemmos, C., Stamatelopoulos, K., Voutsas, A., Stamatelopoulos, S., 1998. Effects of acute cigarette smoking on endotheliumdependent arterial dilatation in normal subjects. Am. J. Cardiol. 81, 1225-1228. 
Leone, A., 1995. Cigarette smoking and health of the heart. J. R. Soc. Health 115, 354355.

Letizia, C., Cerci, S., Subioli, S., Scuro, L., Clemente, G., 1997. Increased plasma endothelin after nicotine consumption in nonsmokers. Clin. Chem. 43, 2440-2441.

Levenson, J., Simon, A.C., Cambien, F.A., Beretti, C., 1987. Cigarette smoking and hypertension. Factors independently associated with blood hyperviscosity and arterial rigidity. Arteriosclerosis 7, 572-577.

Levin, E.R., 1995. Endothelins. N. Engl. J. Med. 333, 356-363.

Li, W.Q., Qureshi, H.Y., Liacini, A., Dehnade, F., Zafarullah, M., 2004. Transforming growth factor Betal induction of tissue inhibitor of metalloproteinases 3 in articular chondrocytes is mediated by reactive oxygen species. Free Radic. Biol. Med. 37:196207.

Lindholt, J.S., Jorgensen, B., Shi, G.P., 2003. Henneberg EW. Relationships between activators and inhibitors of plasminogen, and the progression of small abdominal aortic aneurysms. Eur. J. Vasc. Endovasc. Surg. 25, 546-551.

Lindholt, J.S., Heegaard, N.H., Vammen, S., 2001. Smoking, but not lipids, lipoprotein(a) and antibodies against oxidised LDL, is correlated to the expansion of abdominal aortic aneurysms. Eur. J. Vasc. Endovasc. Surg. 21, 51-56.

Lüscher, T.F., Boulanger, C.M., Dohi, Y., Yang, Z.H., 1992. Endothelium-derived contracting factors. Hypertension 19, 117-130.

Mackay, J., Ericksen, M.P., 2002. The tobacco atlas, World Health Organization, Geneva. 2002,36 .

MacSweeney, S.T., Ellis, M., Worrell, P.C., 1994. Smoking and growth rate of small abdominal aortic aneurysms. Lancet 344, 651-652.

Maeda, S., Miyauchi, T., Goto, K., Matsuda, M., 1997. Differences in the change in the time course of plasma endothelin-1 and endothelin-3 levels after exercise in humans. The response to exercise of endothelin- 3 is more rapid than that of endothelin- 1 . Life Sci. 61, 419-25.

Maeda, S., Miyauchi, T., Kakiyama, T., Sugawara, J., Iemitsu, M., Irukayama-Tomobe, Y., Murakami, H., Kumagai, Y., Kuno, S., Matsuda, M., 2001. Effects of exercise training of 8 weeks and detraining on plasma levels of endothelium-derived factors, endothelin-1 and nitric oxide, in healthy young humans. Life Sci. 69, 1005-1016.

Mahmud, A., Feely, J., 2003. Effect of smoking on arterial stiffness and pulse pressure amplification. Hypertension 41, 183-187. 
Marc, O., Potocnik, N., Starc, V., 2000. Non-invasive beat-to-beat determination of changes in the small artery compliance after smoking. Pflugers. Arch. 439, R211R212.

Maresh, J.G., Xu, H., Jiang, N., Gairola, C.G., Shohet, R.V., 2005. Tobacco smoke dysregulates endothelial vasoregulatory transcripts in vivo. Physiol. Genomics. 21, 308-313.

Masaki, T., 1995. Possible role of endothelin in endothelial regulation of vascular tone. Annu Rev Pharmacol Toxicol. 35, 235-255.

Matetzky, S., Tani, S., Kangavari, S., Dimayuga, P., Yano, J., Xu, H., Chyu, K.Y., Fishbein, M.C., Shah, P.K., Cercek, B., 2000. Smoking increases tissue factor expression in atherosclerotic plaques: implications for plaque thrombogenicity. Circulation 102, 602-604.

Mayhan, W.G., 1999. Acute infusion of nicotine potentiates norepinephrine-induced vasoconstriction in the hamster cheek pouch. J. Lab. Clin. Med. 133, 48-54.

Mazak, I., Wittmann, I., Wagner, L., Wagner, Z., Degrell, P., Vas, T., Molnar, G.A., Nagy. J., 2002. Cigarette smoke and its formaldehyde component inhibit bradykinininduced calcium increase in pig aortic endothelial cells. Endothelium 9,103-108.

Mazzone, A., Cusa, C., Mazzucchelli, I., Vezzoli, M., Ottini, E., Ghio, S., Tossini G., Pacifici, R., Zuccaro, P., 2001. Cigarette smoking and hypertension influence nitric oxide release and plasma levels of adhesion molecules. Clin. Chem. Lab. Med. 39, $822-826$.

McVeigh, G.E., Lemay, L., Morgan, D., Cohn, J.N., 1996. Effects of long-term cigarette smoking on endothelium-dependent responses in humans. Am J Cardiol. 78, 668-672.

Michaud, S.E., Dussault, S., Haddad, P., Groleau, J., Rivard, A., 2006. Circulating endothelial progenitor cells from healthy smokers exhibit impaired functional activities. Atherosclerosis 187, 423-432.

Migneault, A., Sauvageau, S., Villeneuve, L., Thorin, E., Fournier, A., Leblanc, N., Dupuis, J., 2005. Chronically elevated endothelin levels reduce pulmonary vascular reactivity to nitric oxide. Am. J. Respir. Crit. Care. Med. 171, 506-513.

Miller, F.J., Gutterman, D.D., Rios, C.D., Heistad, D.D., Davidson, B.L., 1998. Superoxide production in vascular smooth muscle contributes to oxidative stress and impaired relaxation in atherosclerosis. Circ. Res. 82, 1298-1305.

Mitaka, C., Hirata, Y., Nagura, T., Tsunoda, Y., Amaha, K., 1993. Circulating endothelin1 concentrations in acute respiratory failure. Chest $104,476-480$. 
Murohara, T., Kugiyama, K., Ohgushi, M., Sugiyama, S., Yasue, H., 1994. Cigarette smoke extract contracts isolated porcine coronary arteries by superoxide anionmediated degradation of EDRF. Am. J. Physiol. 266, H874-H880.

Nagy, J., Demaster, E.G., Wittman, I., Shultz, P., Raij, L., 1997. Induction of endothelial cell injury by cigarette smoke. Endothelium 5, 251-263.

Naruse, M., Naruse, K., Demura, H., 1994. Recent advances in endothelin research on cardiovascular and endocrine systems. Endocr. J. 41, 491-507.

Nedeljkovic, Z.S., Gokce, N., Loscalzo, J., 2003. Mechanisms of oxidative stress and vascular dysfunction. Postgrad. Med. J. 79, 195-200.

Nene, S., Gelabert, H., Moore, W., Quinones-Baldrich, W., Santibanez-Gallerani, A., Ignarro, L., 1997.Cigarette smoking increases endothelial-derived vasorelaxation in the rat carotid artery in a dose-dependent manner. J. Surg. Res. 71, 101-106.

Newby, D.E., Wright, R.A., Labinjoh, C., Ludhlam, C.A., Fox, K.A., Boon, N.A., Webb, D.J., 1999. Endothelial dysfunction, impaired endogenous fibrinolysis, and cigarette smoking: a mechanism for arterial thrombosis and myocardial infarction. Circulation 99, 1411-1415.

Nicholls, D.G., Budd, S.L., 2000. Mitochondria and neuronal survival. Physiol. Rev., 80, 315-360.

Orem, A., Orem, C., Alioglu, Y., Vanizor, B., Erdol, C., 2001. Effects of coronary angiography on Plasma endothelin-1 and nitric oxide concentrations. Angiology, 52, 231-235.

Ota, Y., Kugiyama, K., Sugiyama, S., Ohgushi, M., Matsumura, T., Doi, H., Ogata, N., Oka, H., Yasue, H., 1997. Impairment of endothelium-dependent relaxation of rabbit aortas by cigarette smoke extract--role of free radicals and attenuation by captopril. Atherosclerosis 131, 195-202.

Otsuka, R., Watanabe, R., Hirata, K., Tokai, K., Muro, T., Yoshiyama, M., Takeuchi, K., Yoshikawa, J., 2001. Acute effects of passive smoking on the coronary circulation in healthy young adults. JAMA 286, 436-341.

Panagiotakos, D.B., Chrysohoou, C., Pitsavos, C., Papaioannou, I., Skoumas, J., Stefanadis, C., Toutouzas, P., 2002. The association between secondhand smoke and the risk of developing acute coronary syndromes, among non-smokers, under the presence of several cardiovascular risk factors: The CARDIO2000 case-control study. BMC Public Health 2: 9. 
Pechacek, T.F., Asma, S., Blair, N., Eriksen, M.P., 2003. Tobacco: global and community solutions. In: S Yusuf, JA Cairns, AJ Camm, EL Fallen and BJ Gersh, Editors, Evidence-based cardiology (2nd edn.), BMJ Books, London, 103-113.

Penn, A., Chen, L-C, Snyder, C.A., 1994. Inhalation of steady-state sidestream smoke from one cigarette promotes arteriosclerotic plaque development. Circulation 90, 1363-1367.

Perlstein, T.S., Lee, R.T., 2006. Smoking, metalloproteinases, and vascular disease. Arterioscler. Thromb. Vasc. Biol. 26, 250-256.

Peto, R., Lopez, A., 2001. The future worldwide health effects of current smoking patterns. In: CE Koop, CE Pearson and MR Schwarz, Editors, Critical issues in global health, Jossey-Bass, San Francisco, 2001, 154-161.

Petrik, P.V., Gelabert, H.A., Moore, W.S., Quinones-Baldrich, W., Law, M.M., 1995. Cigarette smoking accelerates carotid artery intimal hyperplasia in a dose-dependent manner. Stroke 26, 1409-1414.

Phillips, P.G., Birnby, L.M., 2004. Nitric oxide modulates caveolin-1 and matrix metalloproteinase-9 expression and distribution at the endothelial cell/tumor cell interface. Am. J. Physiol. Lung Cell Mol. Physiol. 286, L1055-L1065.

Pittilo, R.M., Bull, H.A., Gulati, S., Rowles, P.M., Blow, C.M., Machin, S.J., Woolf, N., 1990. Nicotine and cigarette smoking: effects on the ultrastructure of aortic endothelium. Int. J. Exp. Pathol. 71, 573-586.

Poredos, P., Orehek, M., Trantik, E., 1999. Smoking is associated with dose-related increase of intima-media thickness and endothelial dysfunction. Angiology 50, 201208.

Pryor, W.A., Stone, K., Zang, L.Y., Bermudez, E., 1998. Fractionation of aqueous cigarette tar extracts: fractions that contain the tar radical cause DNA damage. Chem. Res. Toxicol. 11, 441-448.

Pryor, W.A., Stone, K., 1993. Oxidants in cigarette smoke. Radicals, hydrogen peroxide, peroxynitrate, and peroxynitrite. Ann. N. Y. Acad. Sci. 686,12-27.

Rahman, M.M., Elmi, S., Chang, T.K.H., Bai, N., Sallam, N.A., Lemos, V.S., MoienAfshari, F., Laher, I., 2006. Increased vascular contractility in isolated vessels from cigarette smoking rats is mediated by basal endothelin release. Vasc. Pharmacol. [In press] 
Raij, L., DeMaster, E.G., Jaimes, E.A., 2001. Cigarette smoke-induced endothelium dysfunction: role of superoxide anion. J Hypertension 19, 891-897.

Rajagopalan, S., Meng, X.P., Ramasamy, S., Harrison, D.G., Galis, Z.S., 1996. Reactive oxygen species produced by macrophage-derived foam cells regulate the activity of vascular matrix metalloproteinases in vitro. Implications for atherosclerotic plaque stability. J. Clin. Invest. 98, 2572-2579.

Rehill, N., Beck, C.R., Yeo, K.R., Yeo, W.W., 2006. The effect of chronic tobacco smoking on arterial stiffness. Br. J. Clin. Pharmacol. 61, 767-773.

Rubanyi, G.M., Vanhoutte, P.M., 1986. Superoxide anions and hyperoxia inactivate endothelium-derived relaxing factor. Am J Physiol: Heart Circ Physiol. 250, H822H827.

Sabha, M., Tanus-Santos, J.E., Toledo, J.C., Cittadino, M., Rocha, J.C., Moreno, H. Jr., 2000.Transdermal nicotine mimics the smoking-induced endothelial dysfunction. Clin. Pharmacol. Ther. 68, 167-174.

Sakurai, T., Yanagisawa, M., Takuwa, Y., Miyazaki, H., Kimura, S., Goto, K., Masaki, T., 1990. Cloning of a cDNA encoding a non-isopeptide-selective subtype of the endothelin receptor. Nature 348, 732-735.

Sarabi, M., Lind, L., 2000. Short-term effects of smoking and nicotine chewing gum on endothelium-dependent vasodilation in young healthy habitual smokers. J. Cardiovasc. Pharmacol. 35, 451-456.

Sarkar, R., Gelabert, H.A., MohiuddinK, R., Thakor, D.K., Santibanez-Gallerani, A.S., 1999. Effect of cigarette smoke on endothelial regeneration in vivo and nitric oxide levels. J. Surg. Res. 82, 43-47.

Scott, T., 1996. Cardiovascular effects of environmental tobacco smoke. Circulation 94: 599.

Shah, P.K., 1997. Inflammation, metalloproteinases, and increased proteolysis: an emerging pathophysiological paradigm in aortic aneurysm. Circulation 96, 21152117.

Shapiro, S.D., 2000. Evolving concepts in the pathogenesis of chronic obstructive pulmonary disease. Clin. Chest Med. 21, 621-632.

Shapiro, S.D., 2002. Proteinases in chronic obstructive pulmonary disease. Biochem. Soc. Trans. 30, 98-102.

Shapiro, S.D., 1995. The pathogenesis of emphysema: the elastase: antielastase hypothesis 30 years later. Proc. Assoc. Am. Physicians 107, 346-352. 
Sinha, A.K., Misra, G.C., Patel, D.K., 1995. Effects of cigarette smoking on lipid profile in the young. J. Assoc. Physicians India 43, 185-188.

Smith, C.J., Fischer, T.H., 2001. Particulate and vapor phase constituents of cigarette mainstream smoke and risk of myocardial infarction. Atherosclerosis 158, 257-267.

Southgate, K.M., Fisher, M., Banning, A.P., Thurston, V.J., Baker, A.H., Fabunmi, R.P., Groves, P.H., Davies, M., Newby, A.C., 1996. Upregulation of basement membranedegrading metalloproteinase secretion after balloon injury of pig carotid arteries. Circ. Res. 79, 1177-1187.

Steenland, K., Thun, M., Lally, C., Heath, C., 1996. Environmental tobacco smoke and coronary heart disease in the American Cancer Society CPS-II cohort. Circulation 94, 622-628.

Stefanadis, C., Vlachopoulos, C., Tsiamis, E., Diamantopoulos, L., Toutouzas, K., Giatrakos, N., Vaina, S., Tsekoura, D., Toutouzas, P., 1998. Unfavorable effects of passive smoking on aortic function in man. Ann. Intern. Med. 128, 426-434.

Stefanadis, C., Vlachopoulos, C., Tsiamis, E., Diamantopoulos, L., Toutouzas, K., Giatrakos, N., Vaina, S., Tsekoura, D., Toutouzas, P., 1998. Unfavorable effects of passive smoking on aortic function in men. Ann. Intern. Med. 128, 426-434.

Su, Y., Cao, W., Han, Z., Block, E.R., 2004. Cigarette smoke extract inhibits angiogenesis of pulmonary artery endothelial cells: the role of calpain. Am. J. Physiol. Lung Cell Mol. Physiol. 287, L794-800.

Su, Y., Han, W., Giraldo, C., De Li Y., Block, E.R., 1998. Effect of cigarette smoke extract on nitric oxide synthase in pulmonary artery endothelial cells. Am. J. Respir. Cell. Mol. Biol. 19, 819-825.

Sumida, H., Watanabe, H., Kugiyama, K., Ohgushi, M., Matsumura, T., Yasue, H., 1998. Does passive smoking impair endothelium-dependent coronary artery dilation in women? J. Am. Coll. Cardiol. 31, 811-815.

Sun, Y.P., Zhu, B.Q., Sievers, R.E., Glantz, S.A., Parmley, W.W., 1994. Metoprolol does not attenuate atherosclerosis in lipid-fed rabbits exposed to environmental tobacco smoke. Circulation 89, 2260-2265.

Tanriverdi, H., Evrengul, H., Kuru, O., Tanriverdi, S., Seleci, D., Enli, Y., Kaftan, H.A., Kilic, M., 2006. Cigarette smoking-induced oxidative stress may impair endothelial function and coronary blood flow in angiographically normal coronary arteries. Circ. J. 70, 593-599. 
Tappia, P.S., Troughton, K.L., Langley-Evans, S.C., Grimble, R.F., 1995. Cigarette smoking influences cytokine production and antioxidant defenses. Clin Sci (Lond) 88, 485-489.

Taylor, A.E., Johnson, D.C., Kazemi, H., 1992. Environmental tobacco smoke and cardiovascular disease: a position paper from the Council on Cardiopulmonary and Critical Care, American Heart Association. Circulation 86, 1-4.

Teo, K. K., Ounpuu, S., Hawken, S., Pandey, M.R., Valentin, V., Hunt, D., Diaz, R., Rashed, W., Freeman, R., Jiang, L., Zhang, X., Yusuf, S., 2006. Tobacco use and risk of myocardial infarction in 52 countries in the INTERHEART study: a case-control study. The Lancet 368, 647-658.

Thompson, R.W., Parks, W.C., 1996. Role of matrix metalloproteinases in abdominal aortic aneurysms. Ann. N.Y. Acad. Sci. 800, 157-174.

Thorin, E., Cernacek, P., Dupuis, J., 1998. Endothelin-1 regulates tone of isolated small arteries in the rat: effect of hyperendothelinemia. Hypertension 31, 1035-1041.

Thun, M.J., da Costa e.Silva, V.L., 2003. Introduction and overview of global tobacco surveillance, Tobacco control country profiles (2nd edition.), World Health Organization, Geneva (2003). 41.

Torok, J., Gvozdjakova, A., Kucharska, J., Balazovjech, I., Kysela, S., Simko, F., Gvozdjak, J., 2000. Passive smoking impairs endothelium-dependent relaxation of isolated rabbit arteries. Physiol. Res. 49, 135-141.

Tracy, R.P., Psaty, B.M., Macy, E., Bovill, E.G., Cushman, M., Cornell, E.S., Kuller, L.H., 1997. Lifetime smoking exposure affects the association of C-reactive protein with cardiovascular disease risk factors and subclinical disease in healthy elderly subjects. Arterioscler. Thromb. Vasc. Biol. 17, 2167-2176.

Ueda, S., Matsuoka, H., Miyazaki, H., Usui, M., Okuda, S., Imaizumi, T., 2000. Tetrahydrobiopterin restores endothelial function in long-term smokers. J. Am. Coll. Cardiol. 35, 71-75.

Ueno, H., Pradhan, S., Schlessel, D., Hirasawa, H., Sumpino, B.E., 2006. Nicotine enhances human vascular endothelial cell expression of ICAM-1 and VCAM-1 via protein kinase $\mathrm{C}, \mathrm{p} 38$ mitogen-activated protein kinase, NF-kappaB, and AP-1. Cardiovasc. Toxicol. 6, 39-50.

Vardulaki, K.A., Walker, N.M., Day, N.E., 2000. Quantifying the risks of hypertension, age, sex and smoking in patients with abdominal aortic aneurysm. Br. J. Surg. 87, 195-200. 
Vasquez-Vivar, J., Kalyanaraman, B., Martasek, P., Hogg, N., Masters, B.S.S., Karoui, H., Tordos, P., Pritchard Jr, K.A., 1998. Superoxide generation by endothelial nitric oxide synthase: the influence of cofactors. Proc. Natl. Acad. Sci. U.S.A. 95, 92209225 .

Verma, S., Anderson, T.J., 2002. Fundamentals of endothelial function for the clinical cardiologist. Circulation 105, 546-549.

Wang, J., Wilcken, D.E., Wang, X.L., 2001. Cigarette smoke activates caspase-3 to induce apoptosis of human umbilical venous endothelial cells. Mol. Genet. Metab. 72, 82-88.

Wang, X.L., Greco, M., Sim, A.S., Duarte, N., Wang, J., Wilcken, D.E., 2002. Effect of CYP1A1 MspI polymorphism on cigarette smoking related coronary artery disease and diabetes. Atherosclerosis $162,391-397$.

Wang, X.L., Sim, A.S., Wang, M.X., Murrell, G.A., Trudinger, B., Wang, J. 2000. Genotype dependent and cigarette specific effects on endothelial nitric oxide synthase gene expression and enzyme activity. FEBS Lett. 471, 45-50.

Warner, D.O. 2006. Perioperative abstinence from cigarettes: physiologic and clinical consequences. Anesthesiology 104, 356-367.

Wei, E.P., Kontos, H.A., Christman, C.W., DeWitt, D.S., 1985. Superoxide generation and reversal of acetylcholine-induced cerebral arteriolar dilation after acute hypertension. Circ. Res. 57, 781-787.

Wright, J.L., Dai, J., Zay, K., Price, K., Gilks, C.B., Churg, A., 1999. Effects of cigarette smoke on nitric oxide synthase expression in the rat lung. Lab. Invest. 79, 975-983.

Wright, J.L., Churg. A., 1991. Effect of long term cigarette smoke exposure on pulmonary vascular structure and function in the guinea pig. Exp. Lung. Res. 17, 9971009.

Wright, JL, Jeng, AY, Battistini, B., 2001. Effect of ECE and NEP inhibition on cigarette smoke-induced cell proliferation in the rat lung. Inhal Toxicol. 13, 497-511.

Wright, JL, Sun, JP, Vedal, S., 1997. A longitudinal analysis of pulmonary function in rats during a 12 month cigarette smoke exposure. Eur. Respir. J. 10, 1115-1119.

Wright, J.L., Tai, H., Churg, A., 2004. Cigarette smoke induces persisting increases of vasoactive mediators in pulmonary arteries. Am. J. Respir. Cell Moll Biol. 31, 501509.

Wright, J.L., Tai, H., Dai, J., Churg, A., 2002. Cigarette smoke induces rapid changes in gene expression in pulmonary arteries. Lab. Invest. 82, 1391-1398. 
Wright, J.L., Sun, J.P., Churg, A., 1999. Cigarette smoke exposure causes constriction of rat lung explant airways. Eur. Respir. J. 14,1095-1099.

Yanagisawa, M., Kurihara, H., Kimura, S., Tomobe, Y., Kobayashi, M., Mitsui, Y., Yazaki, Y., Goto, K., Masaki, T., 1988. A novel potent vasoconstrictor peptide produced by vascular endothelial cells. Nature 332, 411-415.

Zeiher, A.M., Schachinger, V., Minners, J., 1995. Long-term cigarette smoking impairs endothelium-dependent coronary arterial vasodilator function. Circulation 92, 10941100 .

Zempo, N., Kenagy, R.D., Au, Y.P., Bendeck, M., Clowes, M.M., Reidy, M.A., Clowes, A.W., 1994. Matrix metalloproteinases of vascular wall cells are increased in ballooninjured rat carotid artery. J. Vasc. Surg. 20, 209-217.

Zempo, N., Koyama, N., Kenagy, R.D., Lea, H.J., Clowes, A.W., 1996. Regulation of vascular smooth muscle cell migration and proliferation in vitro and in injured rat arteries by a synthetic matrix metalloproteinase inhibitor. Arterioscler. Thromb. Vasc. Biol. 16, 28-33.

Zhang, J.Y., Cao, Y.X., Xu, C.B., Edvinsson, L., 2006. Lipid-soluble smoke particles damage endothelial cells and reduce endothelium-dependent dilatation in rat and man. BMC Cardiovasc. Disord. 6:3. doi: 10.1186/1471-2261-6-3.

Zhang, W.Z., Venardos, K., Chin-Dusting, J., Kaye, D.M., 2006. Adverse effects of cigarette smoke on NO bioavailability: role of arginine metabolism and oxidative stress. Hypertension 48, 278-285.

Zhou, M., Ba, Z.F., Chaudry, I.H., Wang, P., 2002. Adrenomedullin binding protein-1 modulates vascular responsiveness to adrenomedullin in late sepsis. Am. J. Physiol. Regul. Integr. Comp. Physiol. 283, R553-R560, 2002.

Zhu, B.Q., Sun, Y.P., Sievers, R.E., Glantz, S.A., Parmley, W.W., Wolfe, C.L., 1994. Exposure to environmental tobacco smoke increases myocardial infarct size in rats. Circulation 89,1282-1290.

Zhu, B.Q., Sun, Y.P., Sievers, .RE., Isenberg, W.M., Glantz, S.A., Parmley, W.W., 1996. Passive smoking increases experimental atherosclerosis in cholesterol-fed rabbits. J. Am. Coll. Cardiol. 21, 225-232. 


\section{INCREASED VASCULAR CONTRACTILITY IN ISOLATED}

VESSELS FROM CIGARETTE SMOKING RATS IS

MEDIATED BY BASAL ENDOTHELIN RELEASE

\subsection{Introduction}

Cigarette smoking is a major risk factor in the etiology of cardiovascular diseases (Raij et al., 2001). For example, about $30 \%$ of Canadians smoke regularly (Survey: Health Canada, 1994) and more than 16000 smoking related deaths occur in Canada each year (Illing et al., 1991), while in the United States cigarette smoking is responsible for more than 200 deaths daily (Czermin and Waldherr, 2003). It is estimated that cigarette smoking accounts for about $76 \%$ of all peripheral vascular disease (Cole et al., 1993) and overshadows all other major risk factors, including diabetes, obesity, hypertension, bloodlipid abnormalities and blood clotting disorders (Castledon et al., 1981).

${ }^{1}$ A version of this chapter has been accepted for publication. Rahman MM, Elmi S, Chang TKH, Bai N, Sallam NA, Lemos VS, Moien-Afshari F, Laher I. (2006). Increased vascular contractility in isolated vessels from cigarette smoking rats is mediated by basal endothelin release. Vascul Pharmacol. [In press] 
It is estimated that when cigarettes are smoked, more than 4000 different chemicals are formed, and are either inhaled through the cigarette as mainstream smoke or from the air as side stream or secondhand smoke (Jonas et al., 1992). The many smoke constituents cause cardiovascular and cerebrovascular diseases. All tissues and organs are susceptible to the harmful effects. of cigarette smoking, with organs of the pulmonary and cardiovascular system being particularly vulnerable (Sin and Mann, 2003). Cigarette smoking presents a particularly important risk factor for atherosclerosis and hypertension by virtue of increases in plasma levels of oxidized lipids (McBride, 1992).

Cigarette smoking consistently impairs endothelial-dependent vasodilation in humans (Poredos et al., 1999; Ueda et al., 2000; Campisi et al., 1998; Campisi et al., 1999) and animals (Nene et al., 1997; Ota et al., 1997; Mayhan, 1999; Mayhan and Patel, 1997). What is less clear is the vascular effect of cigarette smoking on the release of endothelin, a potent vasoconstrictor and mitogen. Endothelin mediates the effects of acute cigarette smoke exposure on cell proliferation of rat airways and pulmonary arterial vessels (Wright et al. 2001). Following chronic cigarette smoking, increases in endothelin levels may play an important role in the pathogenesis of atherosclerosis (Haak et al., 1994). It is thought that in addition to the nicotine present in cigarette smoke, other components such as, carbon monoxide and tar, can also increase plasma endothelin levels (Goerre et al., 1995).

Cigarette smoking raises plasma levels of endothelin in humans (Haak et al., 1994; Goerre et al., 1995) and rats (Wright et al., 2001), possibly by causing an up-regulation of 
gene expression of endothelin synthetic enzymes (Wright et al., 2002). However, there are no reports examining the role of endothelin release on vascular contractile activity in an animal model of cigarette smoking. In this study, we show for the first time that increased vascular constriction caused by cigarette smoking may in part be due to augmented release and or activity of endogenous endothelin as recorded by significantly increased plasma ET-1 levels in smoking rats in addition to a greater inhibition of arterial contractility by bosentan. Significantly increased plasma ET-1 levels in smoking rats also strengthened this finding. In our study, we measured mRNA expression of CYP1A1 and CYP1A2 to confirm that our smoking protocol produced functional alterations and also to find out any link between these cytochrome enzymes and ET-1-mediated vasoconstriction.

\subsection{Methods and materials}

\subsubsection{Animals}

Twenty Sprague-Dawley rats (weighing 35-40 g) were purchased from the UBC Lab Animal Center and randomly divided into smoking and non-smoking, control groups. All protocols were approved by the Animal Care Committee of the University of British Columbia (Appendix A). The rats used in this study were housed in a temperature- and 
humidity-controlled environment with a 12-hour light-dark cycle and had free access to food and water. Body weights were recorded on a weekly basis for the duration of this study.

\subsubsection{Cigarette smoke exposure}

After 1 week of acclimatization, rats in the S group were exposed to cigarette smoke by a standard cigarette-smoking machine designed by Hogg (Simani et al., 1974). Rats were exposed to 6 University of Kentucky IR3F research grade cigarettes (Appendix B) per rat per day for 5 days a week for 16 weeks. This level of exposure leads to carboxyhemoglobin levels of $\sim 5 \%$ (Churg et al., 1987), levels that are similar to those occurring in human smokers (Prignot, 1987). The smoking machine utilized a nose-only chamber where the eyes were protected and the machine allowed for $20 \mathrm{ml}$ puffs to be drawn from each cigarette. The rate of smoking was standardized at 10 puffs per cigarette and delivered at a rate of 1 puff per minute with a cycle of 15 seconds of smoke and 45 of air per minute. The rats were given a 10-minute rest period between cigarettes. Group C was sham-smoked. 


\subsubsection{Vessel contraction studies}

After 16 weeks of cigarette smoke exposure, rats were injected with sodium pentobarbital $(30 \mathrm{mg} / \mathrm{kg}$ ) and heparin $(500 \mathrm{U} / \mathrm{kg}$.) by the intraperitoneal route. After loss of all reflexes, rats were decapitated and the thoracic aortas and the carotid arteries were collected from each animal and placed in ice-cold $\left(4^{\circ} \mathrm{C}\right)$ physiological salt saline (PSS) until use.

\subsubsection{Wire myograph}

The aortas and carotid arteries were cleaned of connective and adipose tissue and cut into 2-mm rings, with special care being taken to not damage the endothelium. The aortic and carotid arterial rings were mounted on tungsten wires (diameter $40 \mu \mathrm{m}$ ) and placed in separate wire myograph chambers (Multi Myograph Model 610 M, Danish Myotech, Aarhus, Denmark). The chambers had a 5-ml capacity and were filled with physiological salt solution (PSS) maintained at $37^{\circ} \mathrm{C}$ and continuously aerated with a gas mixture containing $95 \% \mathrm{O}_{2}$ and $5 \% \mathrm{CO}_{2}$. During the equilibration, the resting tension was gradually increased to $10 \mathrm{mN}$ for aortas and $7 \mathrm{mN}$ for carotid arteries, so that the vessels remained stable at this optimal basal tension for $60 \mathrm{~min}$, during which time the bath solution was changed at 15-minute intervals. The optimal basal tensions were established from preliminary length-active tension curve. The force generated reported in our work is 
the force generated in addition to the baseline tension applied to the vessels.

To both aorta and carotid artery preparations phenylephrine $\left(10^{-9} \mathrm{M}\right.$ to $\left.10^{-5} \mathrm{M}\right)$ was added in a cumulative manner to generate contraction-response curves. After refreshing the PSS several times to re-establish baseline tensions, the vessels were incubated with $10 \mu \mathrm{M}$ bosentan for $30 \mathrm{~min}$. A concentration-response curve to phenylephrine $\left(10^{-9} \mathrm{M}\right.$ to $\left.10^{-5} \mathrm{M}\right)$ was generated again. To investigate the effects of $\mathrm{N}^{\omega}$-nitro-l-arginine methylester (L-NAME), aortic rings were pre-treated with this compound (L-NAME, $10 \mu \mathrm{M}$ ) for $30 \mathrm{~min}$. Similar to the study with bosentan; concentration-response curves to phenylephrine $\left(10^{-9} \mathrm{M}\right.$ to $\left.10^{-5} \mathrm{M}\right)$ were generated before and after incubation with $\mathrm{L}$ NAME.

\subsubsection{CYP1A1 and CYP1A2 gene expression measured by reverse transcription and real-time polymerase chain reaction (RT-PCR)}

Liver samples were collected $(500-700 \mathrm{mg})$ in small plastic tubes, snap frozen in liquid nitrogen and kept at $-80^{\circ} \mathrm{C}$ until further use. Total cellular RNA was isolated using Trizol reagent (Chang et al., 2006), and total RNA concentration was determined using the RiboGreen RNA Quantitation Kit (Jones et al., 1998). Reverse transcription was conducted with Superscript II reverse transcriptase (Chang et al., 2006) and total cDNA 
concentration was determined using the PicoGreen dsDNA Quantitation Kit (Singer et al., 1997). The sequences of the forward and reverse primers used to amplify CYP1A1 cDNA (GenBank accession number X00469) were 5'-CTG-GTT-CTG-GAT-ACC-CAGCTG-3' and 5'-CCT-AGG-GTT-GGT-TAC-CAG-G-3', respectively (Borlak and Thum, 2001). The sequences of the forward and reverse primers used to amplify CYP1A2 cDNA (GenBank accession number K02422) were 5'-TCC-CTC-AGG-AGA-AGA-TTGT-3' and 5'-ACC-TGC-CAC-TGG-TTT-ATG-3', respectively (Ma et al., 2003). The sequences of the forward and reverse primers used to amplify the cDNA of $18 \mathrm{~s}$ rRNA (GenBank accession number V01270) were 5'-CTT-TGG-TCG-CTC-GCT-CCT-C-3' and 5'-CTG-ACC-GGG-TTG-GTT-TTG-AT-3', respectively (Proudnikov et al., 2003). PCR was performed using a real-time DNA thermal cycler (Light Cycler, Roche Diagnostics, Mannheim, Germany). Each $20 \mu \mathrm{l}$ PCR reaction mixture contained $1 \times$ PCR buffer (20 $\mathrm{mM}$ Tris- $\mathrm{HCl}, \mathrm{pH} 8.4$, and $50 \mathrm{mM} \mathrm{KCl}$ ), 1 unit Platinum Taq DNA polymerase, $3 \mathrm{mM}$ magnesium chloride, $10 \mathrm{ng}$ of total cDNA, $200 \mu \mathrm{M}$ deoxynucleoside-5'-triphosphate mix, $0.2 \mu \mathrm{M}$ each of the forward and reverse primers, $0.25 \mathrm{mg} / \mathrm{ml}$ bovine serum albumin, and $2 \mu \mathrm{l}$ of a $3.3 \times$ SYBR green I solution. The amplification conditions were: a) $95^{\circ} \mathrm{C}$ for $1 \mathrm{~s}$, $56^{\circ} \mathrm{C}$ for $6 \mathrm{~s}$, and $72^{\circ} \mathrm{C}$ for $14 \mathrm{~s}(\mathrm{CYP} 1 \mathrm{~A} 1) ;$ b) $95^{\circ} \mathrm{C}$ for $1 \mathrm{~s}, 53^{\circ} \mathrm{C}$ for $6 \mathrm{~s}$, and $72^{\circ} \mathrm{C}$ for $15 \mathrm{~s}$ (CYP1A2); and c) $95^{\circ} \mathrm{C}$ for $1 \mathrm{~s}, 61^{\circ} \mathrm{C}$ for $6 \mathrm{~s}$, and $72^{\circ} \mathrm{C}$ for $10 \mathrm{~s}(18 \mathrm{~s}$ rRNA). In all cases, the initial denaturation was performed at $95^{\circ} \mathrm{C}$ for $5 \mathrm{~min}$. Calibration curves were constructed with known amounts of the respective purified cDNA. The level of CYP1A1 and CYP1A2 gene expression was normalized to that of $18 \mathrm{~s}$ rRNA. 


\subsubsection{Quantitative assay of plasma ET-1 levels}

EDTA-plasma samples from non-smoking and smoking rats were precipitated before determination of ET-1 levels by enzyme immunoassay (EIA) according to the manufacturer's instructions (Biomedica, distributed by Medicorp, Montreal, Quebec, Canada). The detailed methodology of ET-1 measurement is presented in Appendix C.

\subsubsection{Solutions and chemicals}

The composition of the PSS was (in $\mathrm{mM}$ ): $\mathrm{NaCl} 119, \mathrm{KCl} 4.7, \mathrm{KH}_{2} \mathrm{PO}_{4} 1.18, \mathrm{NaHCO}_{3}$ 24, $\mathrm{MgSO}_{4} \cdot 7 \mathrm{H}_{2} \mathrm{O} 1.17, \mathrm{CaCl}_{2}$ 1.6, glucose 5.5 and EDTA 0.026; the $\mathrm{pH}$ was adjusted at 7.4. For $80 \mathrm{mM} \mathrm{KCl}$ buffer the $\mathrm{NaCl}$ in PSS was substituted on an equal molar basis by KCl. All electrolytes, glucose, acetylcholine, L-NAME, and phenylephrine were purchased from Sigma while bosentan was a gift from Actelion Ltd., Switzerland.

\subsubsection{Statistical analysis}

All results are expressed as mean \pm S.E. of $n$ experiments. Data were analyzed with NCSS 2000 and PASS 2000 software using analysis of variance (ANOVA) and/or 
repeated-measures ANOVA with Bonferroni's multiple comparison tests when appropriate. Graphpad Prism, version 3.02, was used to calculate concentration-response of drugs and also to perform unpaired $t$-test comparison for plasma ET-1 levels between control and smoking groups. The results of statistical tests were considered statistically significant at $P<0.05$.

\subsection{Results}

\subsubsection{Effects of cigarette smoking on body weight gain}

Body weight gain of the smoking group was significantly reduced within 7 weeks of cigarette smoke exposure $(308.66 \pm 7.85$ vs. $353.86 \pm 7.65$ for smoking and control groups, respectively, $P<0.01)$. At the 7 th week, the average body weight of the smoking group was $12.77 \%$ less than the control group and this difference increased to $23.64 \%$ at the end of 16 th week $(458.91 \pm 12.91$ vs. $600.96 \pm 10.09$ for smoking and control group, respectively, $P<0.0001$ ) (Figure 2.1). 


\subsubsection{Vasomotor response of aorta}

The maximal contraction in response to adrenergic receptor stimulation with phenylephrine in smoker rat aortas markedly exceeded that of control rat aortas (Figure 2.2). The inhibition of NO production with L-NAME $(10 \mu \mathrm{M})$ resulted in a nearly threefold increase in the maximal contraction in control aortas and 10-15\% increase in smoker aortas (Figure 2.3). An augmented sensitivity to PE of smoker rat aortas is demonstrated in Figure 2.2 Pretreatment of smoker and control aortas with L-NAME resulted in leftward shifts of the concentration-response curve while at the same time increasing the maximal response to phenylephrine (in smoker rats), indicating decreased basal nitric oxide production in smoker rats (Figure 2.3).

The endothelium produces vasoconstrictors such as endothelin (Yanagisawa et al., 1988 and Masaki, 1998) and we examined the effect of cigarette smoking on endogenous endothelin-mediated modulation of vascular contractility. For this, phenylephrine-induced concentration-response curves obtained in the absence and presence of bosentan were compared. 


\subsubsection{Vasomotor response of the carotid artery}

Carotid arteries from smoker rats generated greater contraction in response to adrenergic receptor stimulation with phenylephrine than those from control rats (Figure 2.4). Incubation with bosentan caused a greater reduction in phenylephrine induced contraction in smoker rat carotid arteries than in carotid arteries obtained from control rats, suggesting a greater role for endothelin release under basal conditions in the cigarette smoking groups.

\subsubsection{Liver enzyme CYP 1A1 and CYP 1A2 gene expression}

Liver samples were analyzed for CYP1A1 and CYP1A2 gene expression by real-time PCR and the data normalized to 18s rRNA (Figure 2.5). Based on real-time PCR, CYP1A1 and CYP1A2 gene expression was 25.13-fold and 13.95-fold greater in the smoking group compared to the control group, and the increases were significant for CYP 1A1 $(P<0.001)$ as well as for CYP $1 \mathrm{~A} 2(P<0.05)$ (Table 2.1). 


\subsubsection{Plasma ET-1 levels}

Plasma ET-1 levels in smoking rats were $2.825 \pm 0.070 \mathrm{fmol} / \mathrm{ml}$, a value significantly higher $(P<0.0001)$ than that in non-smoking control rats $(0.7906 \pm 0.058 \mathrm{fmol} / \mathrm{ml})$ (Figure 2.6). 


\subsection{Discussion}

\subsubsection{Vasoconstriction study}

This study demonstrates vascular dysfunction in cigarette smoking rats. This dysfunction is manifested by an increased contractile response of vascular smooth muscle to $\alpha$ adrenergic stimulation and a decreased regulation of vascular tone by reduced release of basal NO level in the aorta of smoker rats. The reduced body weight gain and increased mRNA expression of CYP1A1 and CYP1A2 in the smoker rats confirm systemic effects to cigarette smoke in these rats.

Cigarette smoking directly elevates plasma leptin concentrations (Nicklas et al., 1999); leptin stimulates smooth muscle cell proliferation and migration (Oda et al., 2001 and Goetz et al., 2002) and vascular wall calcification (Parhami et al., 2001). The increased leptin stimulation of vascular smooth muscle cells leads to cell proliferation and migration, and may contribute, at least in part, to the increased vascular contractility in the smoker rats. 
Increased vascular tone in the cigarette smoker rats may be secondary to both an abnormal response of smooth muscle and endothelial dysfunction. Decreased levels of NO bioavailability in smoker rats vasculature may be due to reduced NO synthesis in the endothelium and/or to enhanced NO breakdown. The increased reactive oxygen species producd in smoker rats (Church et al., 1985; and Chow et al., 1998) could scavenge NO (Clark et al. 2005) and thus indirectly lead to augmented vasoconstriction.

Vascular contraction to $\alpha$-adrenergic-activated contractile response can be mediated by the endothelium-dependent vascular production of endothelin (Arikawa et al., 2001) or angiotensin II (Lemos, 2002; Iida et al., 1998). Thus, the increased vasoconstriction in the smoker rats may not be due only to decreased basal NO but could also be the result of enhanced sensitization of smooth muscle to adrenergic stimulation produced by the endogenous release of endothelin (Henrion and Laher, 1993). Our results from the quantitative assay of plasma levels of endothelin also strengthened this hypothesis.

Smoking is known to increase oxidative stress (Heitzer et al., 2000; Vasquez et al., 1998) and reactive oxygen species induce NO breakdown (Nagy et al., 1997; Ota et al., 1997; Su et al., 1998; Higman et al., 1996) while also increasing contractile prostaglandin production (Yang et al., 2002). Thus, in smoker rats the effect of increased endothelin release at rest coupled with a reduced basal production of NO would lead to increased vascular tone. Other effects of reactive oxygen species such as altering $\mathrm{Ca}_{2}^{+}$extrusion (Liu et al., 2002; Grover et al., 1999), increasing intracellular calcium $\left(\left[\mathrm{Ca}^{2+}\right] \mathrm{i}\right)$ (Li et al., 1999) and reducing $\mathrm{K}^{+}$channel activity (Iida et al., 1998) can also increase vascular 
reactivity.

\subsubsection{Effect of chronic smoking on CYP1A1 and CYP1A2 gene expression}

Tobacco smoke is a mixture of numerous cytochrome P450 substrates, inducers and inhibitors, which can modify cytochrome P450s expression (Czekaj et al., 2005). In our study, we measured CYP1A1 and CYP1A2 gene expression in smoking and control rats to confirm that our smoking protocol produced functional changes, and we found significantly increased expressions of both CYP1A1 and CYP1A2 mRNA. Previous studies have reported that short-term exposure to tobacco smoke-induced both CYP1A1 and CYP1A2 expression (Kawamoto et al., 1993), but that longer exposures (up to 8 weeks) predominantly induced CYP1A1 levels (Wardlaw et al., 1998). Another study has shown that CYP1A1 was preferentially induced by short- and long-term (up to 16 weeks) tobacco smoke exposure (Mori et al., 2003). We exposed the rats for 16 weeks to cigarette smoke and determined that the CYP1A1 mRNA expression was increased 25fold while CYP1A2 mRNA expression was 13-fold higher. The expressions of cigarette smoke-induced liver CYP1A1 and CYP1A2 levels are similar to previous findings (Kawamoto et al. 1993; Wardlaw et al., 1998; and Czekaj et al., 2005). Hercule et al (2000) linked ET-1 to renal production of CYP-arachidonic acid metabolites in the rat isolated kidney; namely, ET-1 released 20-HETE (20-hydroxyeicosatetraenoic acid) associated with renal vasoconstriction. They also found that both $\mathrm{ET}_{\mathrm{A}}$ and $\mathrm{ET}_{\mathrm{B}}$ receptors mediate ET-1 vasoconstriction and that 20-HETE production linked to both receptors 
makes a major contribution to ET-1-induced renal arteriolar vasoconstriction in the rat. Thus, increase level of P450 enzymes are linked with increased ET-1 levels as well as increased vasoconstriction.

\subsubsection{Effects of smoking on plasma ET-1 levels}

ET-1 is the most potent and abundant endogenous vasoconstrictor produced by both the vascular endothelial and smooth muscle cells (Levin, 1995). Only limited data are available on the effects of cigarette smoke or its components on ET-1 levels in the plasma or tissue of human or animal model. Two previous studies performed in human volunteers reported a rise in plasma ET-1 level as a transitory phenomenon (Haak et al, 1994 and Goerre et al, 1995). Results from one of those studies also suggests that the increase in the level of ET-1, a powerful vasoconstrictor and mitogen, may play an important role in the atherogenesis arising from smoking (Haak et al., 1994). Plasma ET-1 concentrations in patients undergoing coronary angiography who were cigarette smokers were found higher than those of patients who were no-smokers (Orem et al, 2001). The increase in plasma ET-1 levels was accompanied by a significant increase in systolic blood pressure in human subjects suggesting the role of the most potent vasoconstrictor - endothelin (Borissova et al, 2004). In another study, it was found that ET-1 increased arterial blood pressure significantly (mean increase 8\%) in smokers (Ottosson-Seeberger et al, 1997). In our study, we found significant increases in plasma ET-1 in chronic cigarette smoking rats $(\mathrm{P}<0.0001)$, which supports our findings of increased vascular contractility in the 
aorta and carotid arteries of cigarette smoking rats. However, we believe that the most likely explanation for our findings resides in ET-1-induced augmentation of reactive oxygen species production in endothelial cells and smooth muscle cells, which in turn contributes to a reduction in the bioavailability of NO (Wedgwood et al, 2001; Li et al, 2003; Callera et al, 2003) resulting in increased vascular contractility.

\subsubsection{Effects of smoking on body weight gain}

Nicotine receptors are present in the appetite-regulating areas of the brain, particularly in the arcuate nucleus of the hypothalamus where nicotine mediates decreases in food intake thereby reducing body weight gain; however, the mechanism by which cigarette smoking or nicotine administration suppresses appetite is not well described (Chen et al, 2005). Cigarette smoking significantly decreases food intake, body weight and fat mass (Chen et al, 2005), and decreases appetite by inhibiting the activity of orexigenic peptides and stimulating the activity of anorexigenic peptides. Cigarette smoking increases plasma levels of catecholamines (Cryer et al., 1976), which in turn reduces plasma leptin levels (Caruli et al., 1999; Fritsche et al., 1998), and reduces food intake (Wellman et al., 2000). Thus, our finding of decreased weight gain caused by cigarette smoking is consistent with the multitudinous effects of plasma nicotine on food intake and energy expenditure. 


\subsection{Conclusion}

In conclusion, this study demonstrates that cigarette smoking induces a pronounced increase of vascular smooth muscle contractility that is associated with reduced basal NO release and augmented endothelin release. These effects were observed in a systemic artery (aorta) as well as a main feeder artery to the cerebral circulation (external carotid artery), suggesting important effects in the mediation of both peripheral and central vascular dysfunction in cigarette smokers. 


\subsection{Tables}

Table 2. 1 Relative mRNA expression (normalized to $18 \mathrm{~s}$ rRNA).

\begin{tabular}{|l|l|l|}
\hline & \multicolumn{2}{|c|}{ Mean \pm SEM } \\
\hline & CYP 1A1 mRNA & CYP 1A2 mRNA \\
\hline Control & $0.0000363 \pm 0.0000135$ & $0.12666666 \pm 0.0166666$ \\
\hline Smoking & $0.0009125 \pm 0.0001057$ & $1.7666667 \pm 0.5886236$ \\
\hline Fold increase & 25.13 & 13.95 \\
\hline$P$-value $(t$-test $)$ & 0.001 & 0.05 \\
\hline
\end{tabular}




\subsection{Figures}

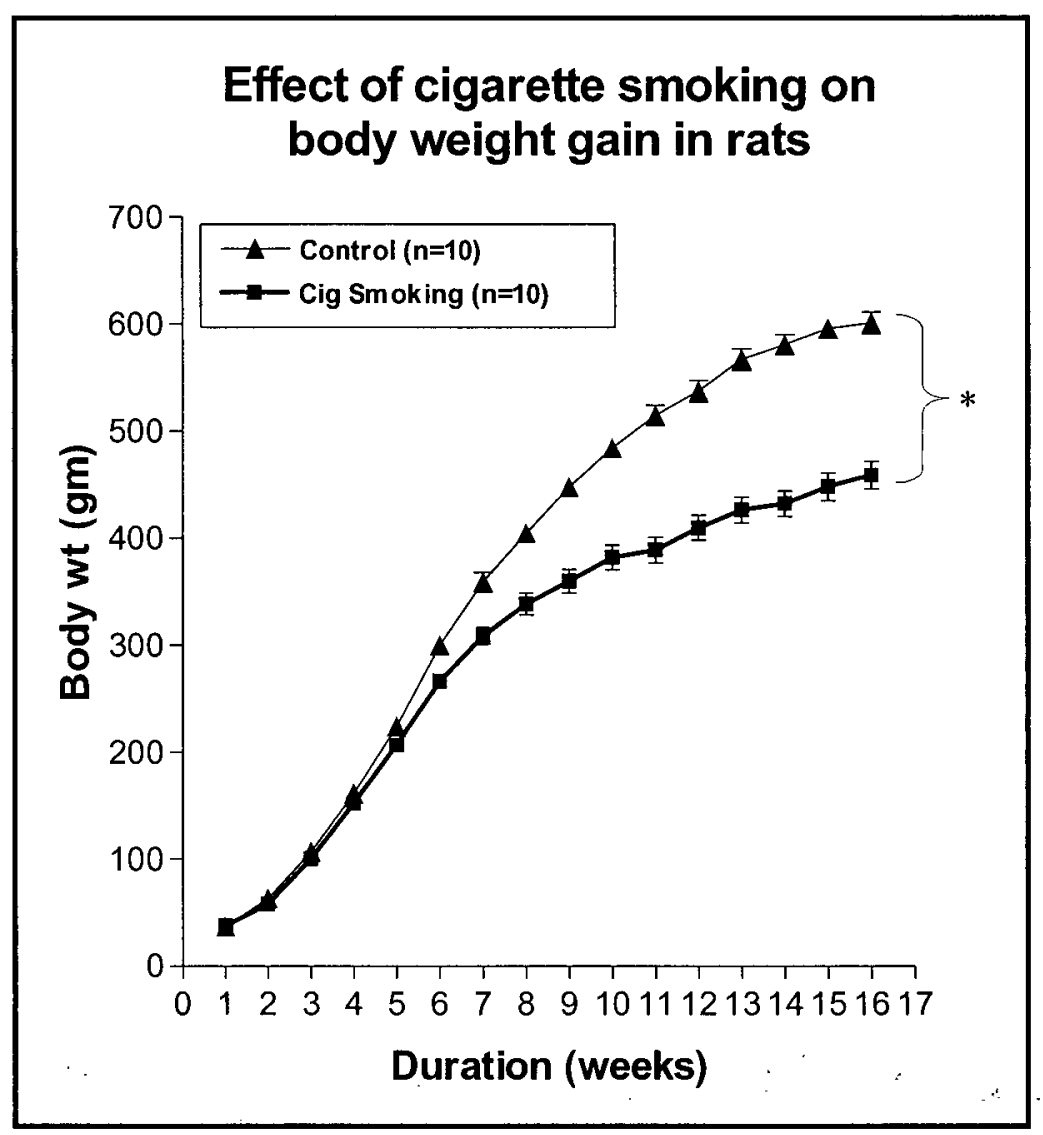

Figure 2. 1 Effect of cigarette smoking on body weight gain. Body weight gain was significantly $(p<0.0001)$ reduced in the smoking rats starting from week 7 through week 16. [ ${ }^{*}=$ Significant difference $(p<0.0001)$ in body weight gain in smokers versus control rats]. 


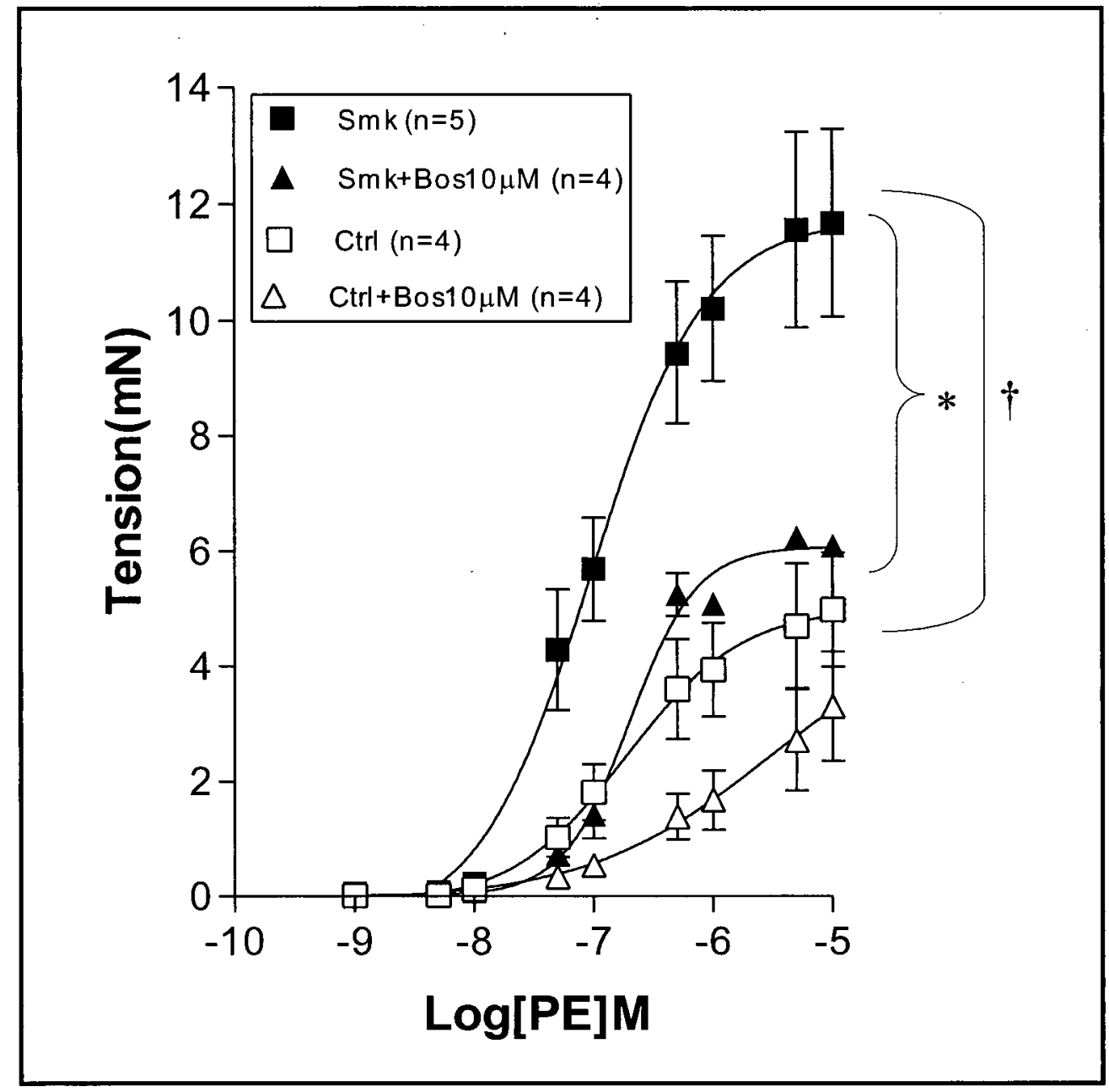

Figure 2. 2 Contractile response of rat aortae. PE-induced contractions in the absence and presence of bosentan in control and smoking rats. ( $\square=$ control before bosentan, $\Delta=$ control after bosentan, $\mathbf{=}=$ smoking before bosentan, $\boldsymbol{\Delta}=$ smoking after bosentan). $[*=$ significant difference $(\mathrm{P}<0.001)$ before and after bosentan treatment in smoking rat aortae. $\uparrow=$ significant difference $(\mathrm{P}<0.001)$ between smoking and control rat aortae before bosentan treatment). 


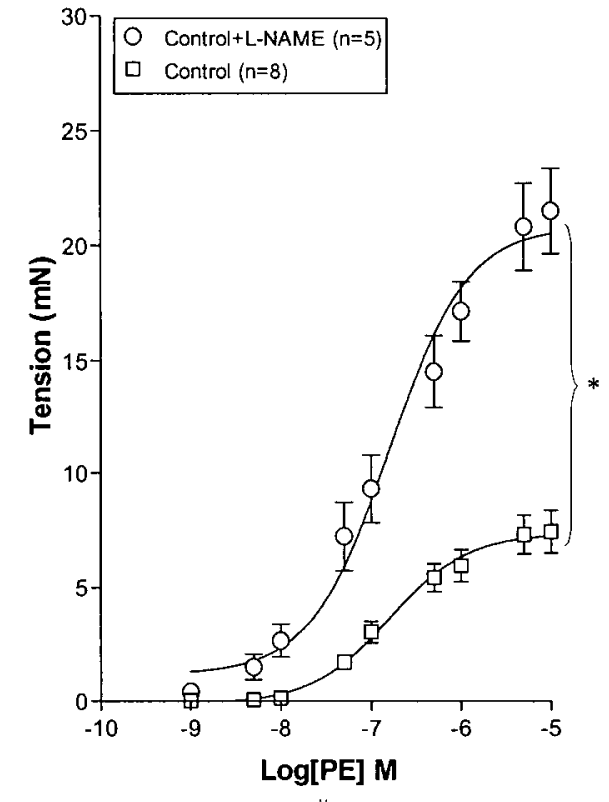

a.

Figure 2. 3 Contractile response of rat aorta. a. PE-induced contractions in the presence and absence of L-NAME in control rat aortae. b. PE-induced contractions in the presence and absence of L-NAME in smoking rat aortae. ( $\square=$ Control before L-NAME, . $\circ=$ Control after L-NAME, $\boldsymbol{\Delta}=$ Smoking before L-NAME, . $\boldsymbol{=}=$ Smoking after L-NAME). [ * = Significant difference $(\mathrm{P}<0.001)$ in $\mathrm{PE}$-response before and after L-NAME incubation]. 


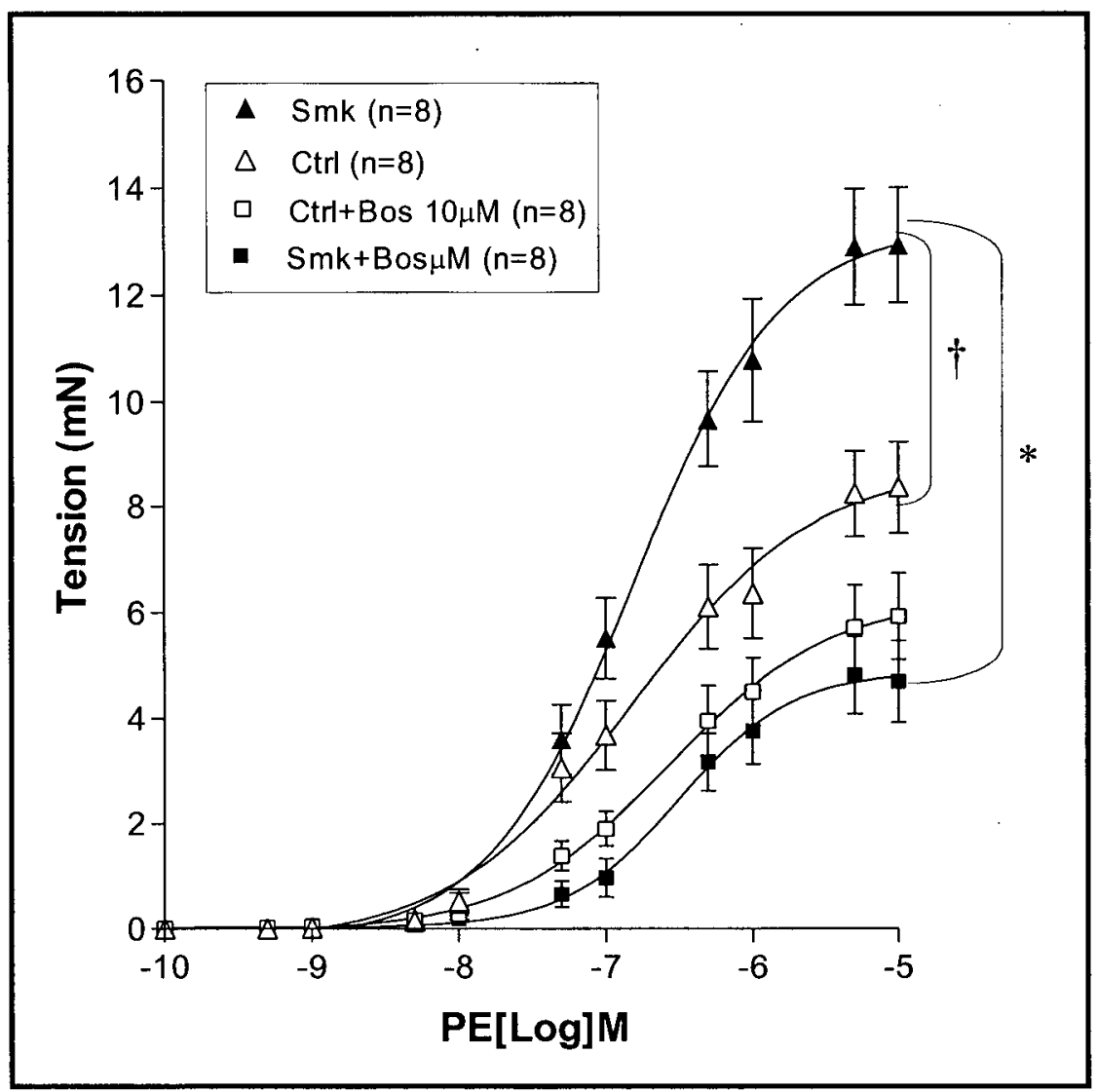

Figure 2. 4 Contractile response of rat carotid arteries. PE-induced contractions in the absence and presence of bosentan in control and smoking rats. ( $\Delta=$ control before bosentan, $\square=$ control after bosentan, $\boldsymbol{\Delta}=$ smoking before bosentan, $\boldsymbol{a}=$ smoking after bosentan). $[\dagger=$ Significant $(\mathrm{P}<0.001)$ difference in $\mathrm{PE}$-induced contraction between smoking and control rat before bosentan treatment; ${ }^{*}=$ significant $(\mathrm{P}<0.001)$ difference in PE-induced contraction in smoking rat aortae before bosentan treatment.] 


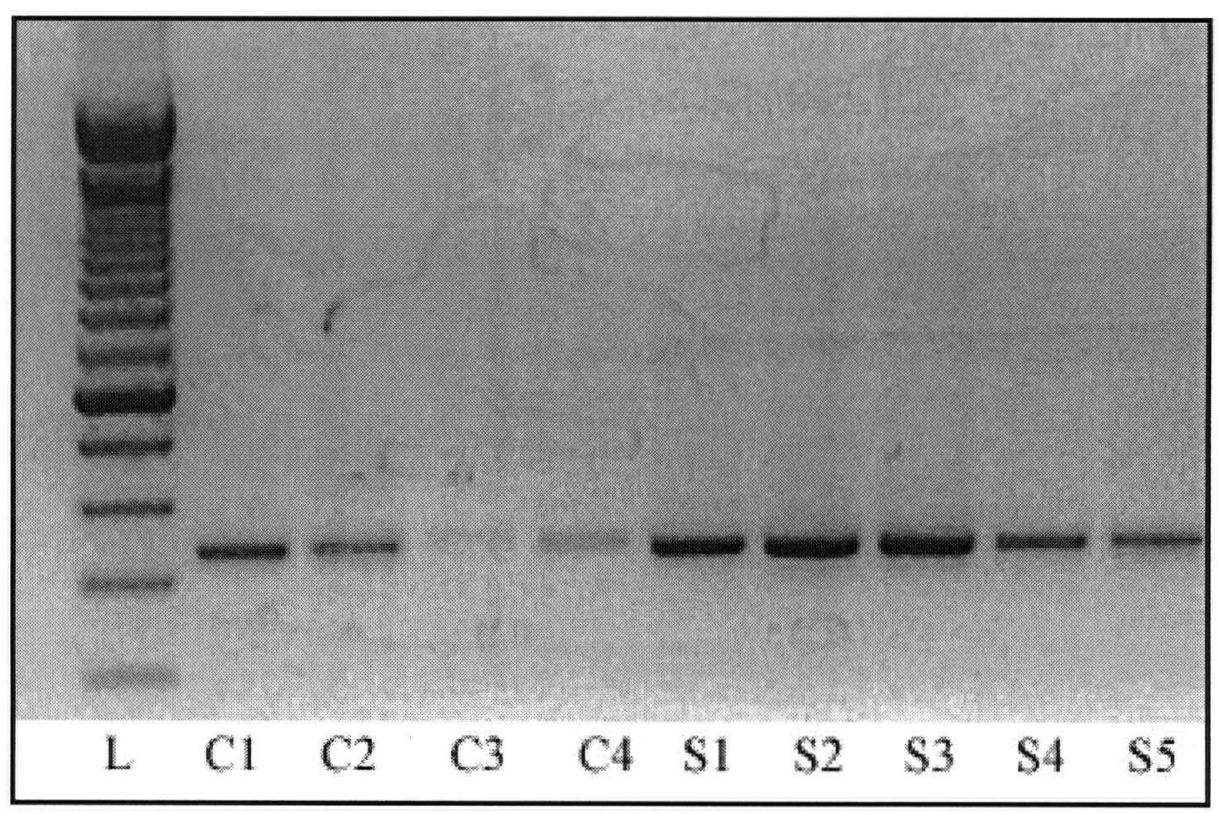

Figure 2. 5 The gel presents results of PCR obtained via thermal block cycler. (L=100bp DNA ladder, C1 -C4=PCR fragments of controls, S1-S5 =PCR fragments of smoking).

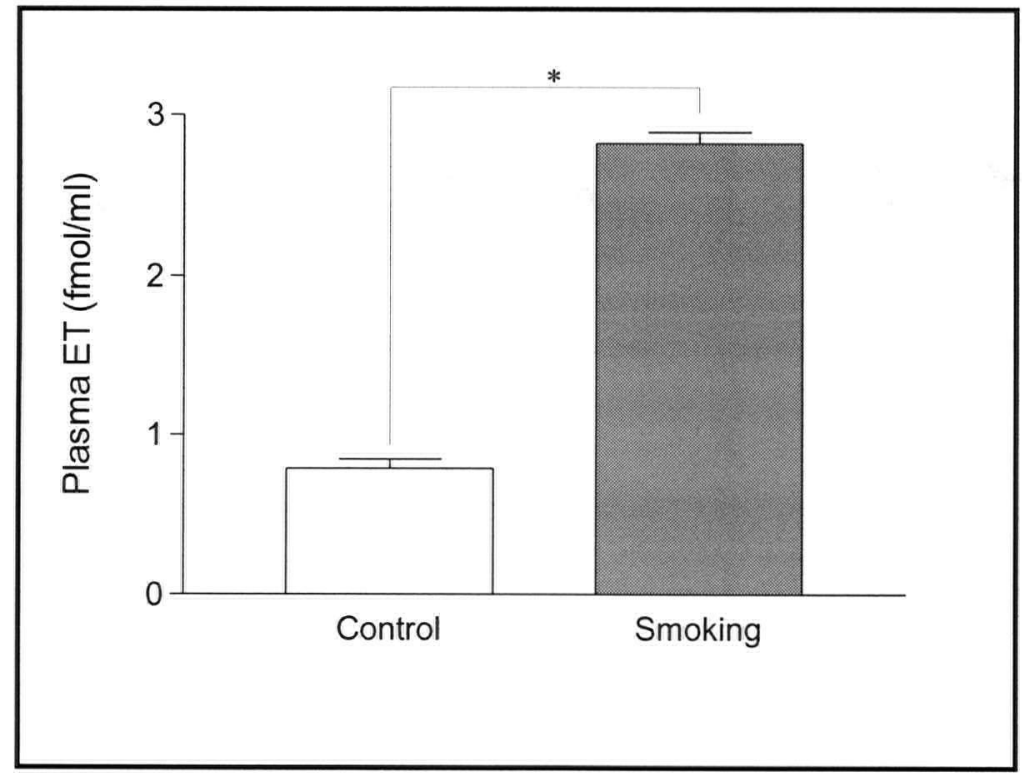

Figure 2. 6 Plasma levels of ET-1 in non-smoking control $(\mathrm{n}=10)$ and smoking rats $(\mathrm{n}=$ 10 ). White bar represents control group, and the solid bar represents smoking group. [* $=$ Significance for unpaired $t$ test comparison is shown $(\mathrm{P}<0.0001)]$. 


\subsection{References}

Arikawa, E., Verma, S., Dumont, A.S., McNeill, J.H., 2001. Chronic bosentan treatment improves renal artery vascular function in diabetes. J Hypertens. 19, 803-812.

Borissova, A.M., Tankova, T., Kirilov, G., Dakovska, L., Krivoshiev, S. 2004. The effect of smoking on peripheral insulin sensitivity and plasma endothelin level. Diabetes Metab. 30, 147-152.

Borlak, J., Thum, T., 2001. Induction of nuclear transcription factors, cytochrome P450 monooxygenases, and glutathione S-transferase alpha gene expression in Aroclor 1254-treated rat hepatocyte cultures. Biochem Pharmacol. 61, 145-153.

Callera, G.E., Touyz, R.M., Teixeira, S.A., Muscara, M.N., Helena, M., Carvalho, C.,

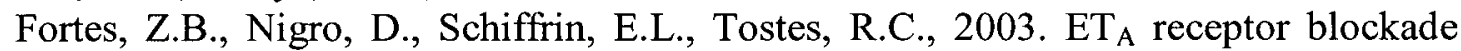
decreases vascular superoxide generation in DOCA-salt hypertension. Hypertension. $42,811-817$.

Campisi, R., Czernin, J., Schoder, H., Sayre, J.W., Schelbert, H.R., 1999. L-Arginine normalizes coronary vasomotion in long-term smokers. Circulation. 99, 491-497.

Campisi R., Czermin J., Schoder H., Sayre J.W., Marengo F.D., Phelps M.E., Schelbert H.R., 1998. Effects of long-term smoking on myocardial blood flow, coronary vasomotion, and vasodilator capacity. Circulation 98, 119-125.

Carulli, L., Ferrari, S., Bertolini, M., Tagliafico, E., and Del Rio G., 1999. Regulation of ob gene expression: evidence for epinephrine-induced suppression in human obesity. J. Clin. Endocrinol. Metab. 84, 3309-3312.

Castleden, W.M., House, A.K., Faulkner, K., and Watt, A., 1981. Haemoglobin, smoking and peripheral vascular disease. J. R. Soc. Med. 74, 586-590.

Chang, T.K.H., Chen, J., Teng, X.W., 2006. Distinct role of bilobalide and ginkgolide A in the modulation of rat CYP2B1 and CYP3A23 gene expression by Ginkgo biloba extract in cultured hepatocytes. Drug Metab. Dispos. 34, 234-242.

Chen, H., Vlahos, R., Bozinovski, S., Jones, J., Anderson, G.P., Morris, M.J., 2005. Effect of short-term cigarette smoke exposure on body weight, appetite and brain neuropeptide $\mathrm{Y}$ in mice. Neuropsychopharmacol. 30, 713-719.

Chow,Y.C., Ma, L., Cho, C.H., 1998. Involvement of free radicals and histamine in the potentiating action of cigarette smoke exposure on ethanol-induced gastric mucosal damage in rats. Free Radic. Biol. Med. 24, 1285-1293. 
Church, D.F., Pryor, W.A., 1985. Free-radical chemistry of cigarette smoke and its toxicological implications. Environ. Health. Perspect. 64, 111-126.

Churg, A., Tron, V., Wright, J.L., 1987. Effects of cigarette smoke exposure on retention of asbestos fibers in various morphologic compartments of the guinea pig lung. Am. J. Pathol. 129, 385-393.

Clark, J.F., Pyne-Geithman, G., 2005. Vascular smooth muscle function: The physiology and pathology of vasoconstriction. Pathophysiology. 12, 35-45.

Cole, C.W., Hill, G.B., Farzad, E., Bouchard, A., Moher, D., Rody, K., Shea, B., 1993. Cigarette smoking and peripheral arterial occlusive disease. Surgery. 114, 753-756.

Cryer, P.E., Haymond, M.W., Santiogo, J.V., Shah, S.D., 1976. Norepinephrine and epinephrine release and adrenergic mediation of smoking-associated homodynamic and metabolic events. N. Engl. J. Med. 295, 573-577.

Czekaj, P., Wiaderkiewicz, A., Florek, E., Wiaderkiewicz, R., 2005. Tobacco smokedependent changes in cytochrome P450 1A1, 1A2, and 2E1 protein expressions in fetuses, newborns, pregnant rats, and human placenta. Arch. Toxicol. 79, 13-24.

Czermin, J., Waldherr, C., 2003. Cigarette smoking and coronary blood flow. Prog. Cardiovasc. Dis. 45, 395-404.

Fritsche, A., Wahl, H.G., Metzinger, E., Renn, W., Kellerer, M., Haring, H. et al., 1998. Evidence for inhibition of leptin secretion by catecholamines in man. Exp. Clin. Endocrinol. Diabetes. 106, 415-418.

Goerre, S., Staehli, C., Shaw, S., Luscher, T.F., 1995. Effect of cigarette smoking and nicotine on plasma endothelin-1 level. J. Cardiovasc. Pharmacol. 26, S236-238.

Goetze, S., Bungenstock, A., Czupalla, C., Eilers, F., Stawowy, P., Kintscher, U., Spencer-Hansch, C., Graf, K., Nurnberg, B., Law, R.E., Fleck, E., Grafe, M., 2002. Leptin induces endothelial cell migration through Akt, which is inhibited by PPAR gamma-ligands. Hypertension. 40, 748-754.

Grover, A.K., Samson, S.E., Misquitta, C.M., Elmoselhi, A.B., 1999. Effects of peroxide on contractility of coronary artery rings of different sizes. Mol. Cell. Biochem. 194, 159-164.

Grover, A.K., Samson, S.E., Misquitta, C.M., Elmoselhi, A.B., 1999. Effects of peroxide on contractility of coronary artery rings of different sizes. Mol. Cell. Biochem. 94, 159-164.

Haak, T., Jungmann, E., Raab, C., Usadel, K, H., 1994. Elevated endothelin-1 level after cigarette smoking. Metabolism. 43, 267-269. 
Heitzer, T., Brockhoff, C., Mayer, B. et al., 2000. Tetrahydrobiopterin improves endothelium-dependent vasodilation in chronic smokers: evidence for a dysfunctional nitric oxide synthase. Circ. Res. 86, E36-E41.

Henrion, D., Laher, I., 1993. Potentiation of the norepinephrine-induced contraction by endothelin $I$ in the rabbit aorta. Hypertension. 27:78-83.

Hercule, H.C., Oyekan, A.O., 2000. Cytochrome P450 omega/omega-1 hydroxylasederived eicosanoids contribute to endothelin(A) and endothelin(B) receptor-mediated vasoconstriction to endothelin-1 in the rat preglomerular arteriole. J Pharmacol Exp Ther. 292, 1153-1160.

Higman, D.J., Strachan, A.M., Buttery, L. et al., 1996. Smoking impairs the activity of endothelial nitric oxide synthase in saphenous vein. Arterioscler. Thromb. Vasc.Biol. $16,546-552$.

Iida M., Iida H., Dohi S., Takenaka M., Fujiwara H., 1998. Mechanisms underlying cerebrovascular effects of cigarette smoking in rats in vivo. Stroke 29, 1656-1665.

Illing, E.M., Kaiserman, M.J., 1995. Mortality attributable to tobacco use in Canada and its regions, 1991. Can. J. Public Health. 86, 257-265.

Jonas, M.A., Oates, J.A., Ockene, J.K., Hennekens, C.H., 1992. Statement on smoking and cardiovascular disease for health care professionals. American Heart Association. Circulation. 86, 1664-1669.

Jones, L.J., Yue, S.T., Cheung, C.Y., Singer, V.L., 1998. RNA quantitation by fluorescence-based solution assay: Ribogreen reagent characterization. Anal. Biochem. 265, 368-374.

Kawamoto T., Yoshikawa M., Matsuno K., Kayama F., Oyama T., Arashidani K., Kodama Y., 1993. Effect of side-stream cigarette smoke on the hepatic cytochrome P450. Arch Environ Contam Toxicol 25, 255-259.

Lemos, V.S., Cortes, S.F., Silva, D.M., Campagnole-Santos, M.J., Santos, R.A., 2002. Angiotensin-(1-7) is involved in the endothelium-dependent modulation of phenylephrine-induced contraction in the aorta of mRen-2 transgenic rats. Br. J. Pharmacol. 135, 1743-1748.

Levin, E.R., 1995. Endothelins. N Engl J Med. 333, 356-63.

Li, L.X., Fink G.D., Watts, S.W. et al., 2003. Endothelin-1 increases vascular superoxide via endothelinA-NADPH oxidase pathway in low-renin hypertension. Circulation. $107,1053-1058$. 
Li, W., Zheng, T., Altura, B.T., Altura, B.M., 1999. Magnesium modulates contractile responses of rat aorta to thiocyanate: A possible relationship to smoking-induced atherosclerosis. Toxicol. Appl. Pharmacol. 57, 77-84.

Liu, Y., Gutterman, D.D., 2002. The coronary circulation in diabetes: Influence of reactive oxygen species on $\mathrm{K}^{+}$channel-mediated vasodilation. Vasc. Pharmacol. 38, 43-49.

Ma, X.C., Wang, H.X., Xin, J., Zhang, T., Tu, Z.H., 2003. Effect of huperzine A on liver cytochrome P-450 in rats. Acta. Pharmacol. Sin. 24, 831-835.

Masaki, T., 1998. The discovery of endothelins. Cardiovasc. Res. 39, 530-533.

Mayhan, W.G., 1999. Acute infusion of nicotine potentiates norepinephrine-induced vasoconstriction in the hamster cheek pouch. J. Lab. Clin. Med. 133, 48-54.

Mayhan, W.G., Patel, K.P., 1997. Effect of nicotine on endothelium-dependent arteriolar dilatation in vivo. Am. J. Physiol. 272, H2337-H2342.

McBride, P.E., 1992. The health consequences of smoking. Cardiovascular diseases. Med. Clin. North Am. 76, 333-353.

Mori Y., Koide A., Kobayashi Y., Furukawa F., Hirose M., Nishikawa A., 2003. Effects of cigarette smoke and a heterocyclic amine, MeIQx on cytochrome P-450, mutagenic activation of various carcinogens and glucuronidation in rat liver. Mutagenesis 18, 8793.

Nagy, J., Demaster, E.G., Wittmann, I. et al., 1997. Induction of endothelial cell injury by cigarette smoke. Endothelium. 5, 251-263.

Nene, S., Gelabert, H., Moore, W., Quinones-Baldrich, W., Santibanez-Gallerani, A., Ignarro, L., 1997. Cigarette smoking increases endothelial-derived vasorelaxation in the rat carotid artery in a dose-dependent manner. J. Surg. Res. 71, 101-106.

Nicklas, B.J., Tomoyasu, N., Muir, J., Goldberg, A.P., 1999. Effects of cigarette smoking and its cessation on body weight and plasma leptin levels. Metabolism. 48, 804-808.

Oda, A., Taniguchi, T., Yokoyama, M., 2001. Leptin stimulates rat aortic smooth muscle cell proliferation and migration. Kobe J. Med. Sci. 47, 141-150.

Orem, A., Orem, C., Alioglu, Y., Vanizor, B., Erdol, C., 2001. Effect of coronary angiography on plasma endothelin-1 and nitric oxide concentrations. Angiology. 52, 231-235. 
Ota, Y., Kugiyama, K., Sugiyama, S., Ohgushi, M., Matsumura, T., Doi, H., Ogata, N., Oka, H., Yasue, H., 1997. Impairment of endothelium-dependent relaxation of rabbit aortas by cigarette smoke extract: role of free radicals and attenuation by captopril. Atherosclerosis. 131, 195-202.

Ottoson-Seeberger, A., Lundberg, J.M., Alvestrand, A., Ahlborg, G., 1997. Exogenous endothelin-1 causes peripheral insulin resistance in healthy humans. Acta Physiol Scand. 161, 211-220.

Parhami, F., Tintut, Y., Ballard, A., Fogelman, A.M., Demer, L.L., 2001 . Leptin enhances the calcification of vascular cells: artery wall as a target of leptin. Circ. Res. 88, 954960.

Poredos, P., Orehek, M., Tratnik, E., 1999. Smoking is associated with dose-related increase of intima-media thickness and endothelial dysfunction. Angiology. 50, 201 208.

Prignot, J., 1987. Quantification and chemical markers of tobacco-exposure. Eur. J. Respir. Dis. 70, 1-7.

Proudnikov, D., Yuferov, V., Zhou, Y., LaForge, K.S., Ho, A., Kreek, M.J., 2003. Optimizing primer-probe design for fluorescent PCR. J. Neurosci. Methods. 123, 3145.

Raij, L., Demaster, E.G., Jaimes, E., 2001. Cigarette smoke-induced endothelium dysfunction: role of superoxide anion. J. Hypertens. 19, 891-897.

Simani, A.S., Inoue, S., Hogg, J.C., 1974. Penetration of the respiratory epithelium of guinea pigs following exposure to cigarette smoke. Lab. Invest. 31, 75-81.

Sin, D.D., Man, S.F., 2003. Why are patients with chronic obstructive pulmonary disease at increased risk of cardiovascular diseases? The potential role of systemic inflammation in chronic obstructive pulmonary disease. Circulation. 107, 1514-1519.

Singer, V.L., Jones, L.J., Yue, S.T., Haugland, R.P., 1997. Characterization of PicoGreen reagent and development of a fluorescence-based solution assay for double-stranded DNA quantitation. Anal. Biochem. 249, 228-238.

Su, Y., Han, W., Giraldo, C. et al., 1998. Effect of cigarette smoke extract on nitric oxide synthase in pulmonary artery endothelial cells. Am. J. Respir. Cell. Mol. Biol. 19, 819-825.

Survey on smoking in Canada. Ottawa: Health Canada (1994). 
Ueda, S., Matsuoka, H., Miyazaki, H., Usui, M., Okuda, S., Imaizumi, T., 2000. Tetrahydro-biopterin restores endothelial function in long-term smokers. J. Am. Coll. Cardiol. 35, 71-75.

Vasquez-Vivar, J., Kalyanaraman, B., Martasek, P. et al., 1998. Superoxide generation by endothelial nitric oxide synthase: the influence of cofactors. Proc. Natl. Acad. Sci. U S A. $95,9220-9225$.

Wardlaw S.A., Nikula K.J., Kracko D.A., Finch G.L., Thornton-Manning J.R., Dahl A.R., 1998. Effect of cigarette smoke on CYP1A1, CYP1A2 and CYP2B1/2 of nasal mucosae in F344 rats. Carcinogenesis 19, 655-662.

Wedgwood, S., Dettman, R.W., Black, S.M. 2001. ET-1 stimulates pulmonary arterial smooth muscle cell proliferation via induction of reactive oxygen species. Am J Physiol Lung Cell Mol Physiol. 281, L1058-L1067.

Wellman, P.J., 2000. Norepinephrine and the control of food intake. Nutrition. 16, 837842.

Wright, J.L., Jeng, A.Y., Battistini, B., 2001. Effect of ECE and NEP inhibition on cigarette smoke-induced cell proliferation in the rat lung. Inhal. Toxicol. 13, 497-511.

Wright, J.L., Tai, H., Dai, J., Churg, A., 2002. Cigarette smoke induces rapid change in gene expression in pulmonary arteries. Lab, Invest. 82, 1391-1398.

Yanagisawa, M., Kurihara, H., Kimura, S. et al., 1988. A novel potent vasoconstrictor peptide produced by vascular endothelial cells. Nature. 332, 411.

Yang, D., Feletou, M., Boulanger, C.M., Wu, H.F., Levens, N., Zhang, J.N., Vanhoutte, P.M., 2002. Oxygen-derived free radicals mediate endothelium-dependent contractions to acetylcholine in aortas from spontaneously hypertensive rats. Br. J. Pharmacol.136, 104-110. 


\section{CONCLUDING CHAPTER}

\section{GENERAL DISCUSSION AND CONCLUSIONS}

\subsection{General discussion}

This study demonstrates vascular dysfunction in cigarette smoking rats with a pronounced increase of vascular smooth muscle contractility that is related to reduced basal NO release and augmented endothelin release. The reduced body weight gain and increased mRNA expression of CYP1A1 and CYP1A2 in the smoker rats confirm systemic effects to cigarette smoke in these rats.

In this study we did not find impairment of endothelium-dependent vasorelaxation either in conduit arteries (data not shown) or in resistance arteries (Appendix D), although we found significant reduction in basal levels of NO. There are different pathways of vasorelaxation: NO-mediated relaxation, EDHF-mediated relaxation, prostacyclinmediated relaxation etc. Thus, NO is mainly but not exclusively responsible for the vasorelaxation (Vequad et al., 1999). In rat gracilis muscle arterioles NO was only partially involved in the dilation. In the same study, prostacyclin was demonstrated to be responsible for the remaining component of the dilation obtained in the absence of NO synthesis (Koller et al., 1994). Prostacyclin biosynthesis is elevated in cigarette smokers (McAdam et al., 2005) and it is an effective vasodilator (Wet et al., 2004). 
Another significant mediator of vasorelaxation is carbon monoxide (CO), which is a potent inducer of hypoxia. Hypoxia will produce endothelial-derived vasorelaxation.

$\mathrm{CO}$ can induce relaxation of vascular tissues with different diameters in different animal models (Wang et al., 1997; Wang, 1998). Exogenously applied CO also induced a concentration-dependent relaxation of rat-tail artery precontracted with phenylephrine. Like NO, CO also stimulates cyclic guanosine monophosphate (cGMP)-mediated pathways. The activation of soluble guanylate cyclase (sGC) results in an increase in cGMP level. In vascular smooth muscle, increased cGMP production subsequently induces relaxation by lowering intracellular calcium concentration. $\mathrm{CO}$ also modulates $\mathrm{K}^{+}$ channels resulting in hyperpolarization, which causes vasorelaxation by inactivating voltage-dependent calcium channels (Wang et al., 1997; Wang, 1998). Rats exposed to cigarette smoke have shown significantly higher amounts of carboxyhemoglobin relative to the controls (Renne et al., 2006; Gentry-Nielsen et al., 2004; Nene et al., 1997). Similarly, human smokers have also shown increased carboxyhemoglobin levels (Hart et al., 2006; Rickert et al., 1981). This increased carboxyhemoglobin level may produce hypoxia which will ultimately produce endothelium-derived vasorelaxation.

Another contributing factor for endothelium-dependent vasorelaxation is ET-1 itself. ET1 acts on three types of G-protein-coupled receptors: $\mathrm{ET}_{\mathrm{A}}, \mathrm{ET}_{\mathrm{B} 1}$ and $\mathrm{ET}_{\mathrm{B} 2}$ (Douglas et al., 1995). Among these three receptors, $\mathrm{ET}_{\mathrm{A}}$ and $\mathrm{ET}_{\mathrm{B} 2}$ are expressed in vascular smooth muscle cells, and $\mathrm{ET}_{\mathrm{B} 1}$ predominantly in the vascular endothelium; the former two are responsible for vasoconstriction while the last one for vasodilation by releasing NO and 
prostacyclin (de Nucci et al., 1988; Sakurai et al., 1990; and Arai et al., 1990). At low concentrations $\mathrm{ET}-1$ mainly acts on the $\mathrm{ET}_{\mathrm{B} 1}$ receptors, thus producing vasodilation (Masaki et al., 1995).

There is evidence that smoking in rats is associated with an increase in serum NO level (Sarkar et al., 1999) that could have a relaxing effect. However, in this study we found decreased basal NO but we did not measure the level of NO in serum or tissue. It would be interesting to measure the NO level directly in the bath solution while doing the functional study in vascular tissue.

\subsection{Comments on strengths and weaknesses of the thesis research}

The strength of the research lies in the fact that by using a rat model, we basically investigated the effects of cigarette smoking as an independent risk factor of cardiovascular disease or disease condition as rats are free from the risk of development of hyperlipidemia or dyslipidemia and atherosclerosis.

The weakness of this study is that we failed to show significant impairment of endothelium-dependent vasodilation both in conduit and resistance arteries of smoker rats (Appendix D, Figure 4.1 and 4.2). In this study, one of the objectives was to examine the endothelium-dependent vasorelaxation by acetylcholine-induced NO production. Experiments addressing this aim failed to show reduction in stimulated NO production in the smoker rats although there was a reduction in basal NO. This could be due to the 
species variation. It is known that rats are resistant to development of atherosclerosis due to high HDL ("good" cholesterol) and low LDL ("bad" cholesterol) (Chapman et al., 1980). This special characteristic of rat may, in part, lead to the failure of showing reduced stimulated NO in smoker rats. So, rat may not be a good model to investigate cigarette smoke-induced endothelial dysfunction. As an alternative model of cigarette smoking, one could use transgenic mice, for example, ApoE deficient mice that readily develop atherosclerosis and this could be good model for investigating endothelial dysfunction.

\subsection{Evaluation of current knowledge and proposals for new ideas related to the field of study}

Cigarette smoking is associated with increased levels of ET-1, which has been implicated in the pathogenesis of COPD, asthma and PH (Hay, 1999; Nikolaou et al., 2003). It is estimated that more than $80 \%$ patients with COPD have been cigarette smokers (Peto et al., 2001) and that more than $50 \%$ of smokers have evidence of COPD (Lundback et al., 2003). It is reported that $91 \%$ of patients with severe COPD have PH (Scharf et 1., 2002). Plasma levels of ET-1 are increased both in patients with severe COPD (Channick et al., 2004) and PH (Yamakami et al., 1997; Moore et al., 2004). ET-1 plays an important role in increasing pulmonary vascular resistance (Vizza et al., 2006). There is also evidence that $\mathrm{ET}_{\mathrm{A}}$ and $\mathrm{ET}_{\mathrm{B}}$ receptor expression is increased in the pulmonary arteries of patients with COPD and PH (Davie et al., 2002). Hypertension in COPD is a result of direct cigarette smoke-mediated effects on the vasculature by ET-1 and that interference with 
ET-1 production and activity may be beneficial (Wright et al., 2006).

We found endothelin-1 (ET-1)-induced vasoconstriction in cigarette smoker rats that can be used as the basis for therapeutic target. For example, in smokers with chronic obstructive pulmonary disease (COPD), asthma or pulmonary hypertension $(\mathrm{PH})$ we can use an ET-1 blocker or an ET-1 antagonist to ameliorate these disease conditions.

In the treatment of pulmonary arterial hypertension the newly added drugs are ET-1 receptor antagonists. For example, bosentan, a mixed $\mathrm{ET}_{\mathrm{A}}$ and $\mathrm{ET}_{\mathrm{B}}$ receptor antagonist, improves exercise tolerance and survival in PAH (Rubin et al., 2002). Investigators can focus on developing new drugs, which could selectively block ET-1 receptor subtypes (e.g., $\mathrm{ET}_{\mathrm{A}}$ or $\mathrm{ET}_{\mathrm{B} 2}$ ) or directly inhibit production and/or release of the constrictor peptide ET-1, thus ameliorating these disease conditions. 


\subsection{Discussion of any potential applications of the research findings}

Cigarette smoking results in increased levels of ET-1, a peptide released from vascular endothelium throughout the body, including the corpus cavernosum, which causes smooth muscle constriction. There is a physiological role of ET-1 in the control of erectile function and it may play a role in detumescence (McVary, 2006; Andersson, 2003; Morano, 2003; Becker et al., 2001); in smokers (Khan et al., 1998) or in patients with COPD (Koseoglu et al., 2005) the situation is worse. A body of evidence shows that there is a link between cigarette smoking, ET-1 and an increased risk of erectile dysfunction (McVary, 2006; Andersson, 2003; Morano, 2003). ET-1 antagonists may be beneficial in the treatment of erectile dysfunction in smokers. Many men with erectile dysfunction do not respond to oral sildenafil or alprostadil injection (Goldenberg, 1998). This group of people may benefit from ET-1 antagonists. 


\subsection{Comments on future research}

For further research, an important therapeutic question to address is whether an oral ET-1 antagonist can improve vascular dysfunction in smokers. There are many unanswered questions relating to endothelin and cigarette smoking. Acute smoking was found to increase ET-1 mRNA but chronic smoking did not (Adachi et al., 2000). Further research should be addressed to clarify this issue. We used bosentan, a dual endothelin receptor blocker, to examine the endothelin-induced augmented vasoconstriction. It would be interesting to use specific receptor blockers and explore the difference in contractile response of the vessels from non-smokers and cigarette smokers to $\alpha$-adrenergic stimulation. 


\subsection{References}

Adachi, C., Naruse, M., Ishihara, Y., Tanabe, A., Takagi, S., Yoshimoto, T., Naruse, K., Kagawa, J., Takano, K., 2000. Effects of acute and chronic cigarette smoking on the expression of endothelin-1 mRNA of the cardiovascular tissues in rats. J Cardiovasc Pharmacol. 36, S198-S200.

Andersson, K.E., 2003. Erectile physiological and pathophysiological pathways involved in erectile dysfunction. J. Urol. 170, S6-S13.

Arai, H., Hori. S., Aramori, I., Ohkubo, H., Nakanishi, S., 1990. Cloning and expression of a cDNA encoding an endothelin receptor. Nature. 348, 730-732.

Becker, A.J., Uckert, S., Stief, C.G., Truss, M.C., Hartmann, U, Jonas, U., 2002. Systemic and cavernosal plasma levels of endothelin (1-21) during different penile conditions in healthy males and patients with erectile dysfunction. World J Urol. 19, 371-376.

Channick, R.N., Sitbon, O., Barst, R.J., Manes, A., Rubin, L.J., 2004. Endothelin receptor antagonists in pulmonary arterial hypertension. J. Am. Coll. Cardiol. 43, 62S-67S.

Chapman, M.J. (1980). Animal lipoproteins: Chemistry, structure, and comparative aspects. Journal of Lipid Research. 21,789-853.

Davie, N., Haleen, S.J., Upton, P.D., Polak, J.M., Yacoub, M.H., Morrell, N.W., Wharton, J., 2002. ETA and ETB receptors modulate the proliferation of human pulmonary artery smooth muscle cells. Am. J. Respir. Crit. Care Med. 165, 389-405.

de Nucci, G., Thomas, R., D'Orleans-Juste, P., Antunes, E., Walder, C., Warner, T.D., Vane, J.R., 1988. Pressor effects of circulating endothelin are limited by its removal in the pulmonary circulation and by the release of prostacyclin and endothelium-derived relaxing factor. Proc Natl Acad Sci USA. 85, 9797-9800.

Douglas, S.A., Beck, G.R. Jr, Elliott, J.D., Ohlstein, E.H., 1995. Pharmacological evidence for the presence of three distinct functional endothelin receptor subtypes in the rabbit lateral saphenous vein. Br J Pharmacol. 114, 1529-1540.

Gentry-Nielsen, M.J., Top, E.V., Snitily, M.U., Casey, C.A., Preheim, L.C., Goldenberg, M.M., 1998. Safety and efficacy of sildenafil citrate in the treatment of male erectile dysfunction. Clin Ther. 20, 1033-1048.

Hart, C.L., Smith, G.D., Hole, D.J., Hawthorne, V.M., 2006. Carboxyhaemoglobin concentration, smoking habit, and mortality in 25 years in the Renfrew/Paisley prospective cohort study. Heart. 92, 321-324. 
Hay, D.W., Putative mediator role of endothelin-1 in asthma and other lung diseases. 1999. Clin. Exp. Pharmacol. Physiol. 26, 168-171.

Khan, M.A., Thompson, C.S., Sullivan, M.E., Dashwood, M.R., Jeremy, J. Y., Morgan, R.J., Mikhailidis, D.P., 1998. Endothelin and erectile dysfunction: a target for pharmacological intervention? Expert Opin. Investig. Drugs. 7, 1759-1767.

Koller, A., Huang, A., 1994. Impaired nitric oxide-mediated flow-induced dilation in arterioles of spontaneously hypertensive rats. Circ Res. 74, 416-421.

Koseoglu, N., Koseoglu, H., Ceylan, E., Cimrin, H.A., Ozalevli, S., Esen, A., 2005. Erectile dysfunction prevalence and sexual function status in patients with chronic obstructive pulmonary disease. J Urol. 174, 249-252.

Lundback, B., Lindberg, A., Lindstrom, M., Ronmark, E., Jonsson, A.C., Jonsson, E., Larsson, L.G., Andersson, S., Sandstrom, T., Larsson, K., 2003. Obstructive lung disease in northern Sweden studies: not 15 but $50 \%$ of smokers develop COPD? Report from the Obstructive Lung Disease in Northern Sweden Studies. Respir. Med. $97,154-161$.

Masaki, T., 1995. Possible role of endothelin in endothelial regulation of vascular tone. Annu Rev Pharmacol Toxicol. 35, 235-255.

McAdam, B.F., Byrne, D., Morrow, J.D. Oates, J.A., 2005. Contribution of cyclooxygenase- 2 to elevated biosynthesis of thromboxane A2 and prostacyclin in cigarette smokers. Circulation. 112,1024-1029.

McVary, K., 2006. Lower urinary tract symptoms and sexual dysfunction: epidemiology and pathophysiology. BJU Int. 97, S23-S28.

Moore, L.G., Shriver, M., Bemis, L., Hickler, B., Wilson, M., Brutsaert, T., Parra, E., Vargas, E., 2004. Maternal adaptation to high altitude pregnancy: an experiment of nature. Placenta 25, 560-571.

Morano, S., 2003. Pathophysiology of diabetic sexual dysfunction. J. Endocrinol. Invest. 26, S65-S69.

Nikolaou, E., Trakada, G., Prodromakis, E., Efremidis, G., Pouli, A., Koniavitou, A., Spiropoulos, K., 2003. Evaluation of arterial endothelin-1 levels, before and during a sleep study, in patients with bronchial asthma and chronic obstructive pulmonary disease. Respiration 70, 606-610.

Peto, R., Lopez, A.D., 2001. Future worldwide health effects of current smoking patterns: In: Koop CE, Pearson CE, Schwartz MR, editors. Critical issues in global health. San Francisco: Jossey-Bass; 154-561. 
Renne, R.A., Yoshimura, H. Yoshino, K., Lulham, G., Minamisawa, S., Tribukait, A., Dietz, D.D., Lee, K.M., Westerberg, R.B., 2006. Effects of flavoring and casing ingredients on the toxicity of mainstream cigarette smoke in rats. Inhal Toxicol. 18, 685-706.

Rubin, L.J., Badesch, D.B., Barst, R.J., Galie, N., Black, C.M., Keogh, A., Pulido, T., Frost, A., Roux, S., Leconte, I., et al. 2002. Bosentan therapy for pulmonary arterial hypertension. N. Engl. J. Med. 346, 896-903.

Sakurai, T., Yanagisawa, M., Takuwa, Y., Miyazaki, H., Kimura, S., Goto, K., Masaki, T., 1990. Cloning of a cDNA encoding a non-isopeptide-selective subtype of the endothelin receptor. Nature. 348,732-735.

Sarkar, R., Gelabert, H.A., Mohiuddin, K.R., Thakor, D.K., Santibanez-Gallerani, A.S., 1999. Effect of cigarette smoke on endothelial regeneration in vivo and nitric oxide levels. J. Surg. Res. 82, 43-47.

Scharf, S.M., Igbol, M., Kellen, C., Criner, G., Lee, S., Fessler, H.E., 2002. Hemodynamic characterization of patient with severe emphysema. Am. J. Respir. Crit. Care Med. 166, 314-322.

Vequaud, P., Pourageaud, F., Freslon, J.L., 1999. Role of nitric oxide and endothelium in the flow-induced dilation of rat coronary arteries under two preconstriction conditions. Clin. Exp. Pharmacol. Physiol. 26, 470-476.

Vizza, C.D., Letizia, C., Badagliacca, R., Sciomer, S., Poscia, R., Della Rocca, G., Iacoboni, C., Leonardo de, L., Quattrucci, S., Dario, C., Luigi, P., Fedele, F., 2006. Plasma adrenomedullin and endothelin-1 concentration during low-dose dobutamine infusion: Relationship between pulmonary uptake and pulmonary vascular pressure/flow characteristics. Regul. Pept. 136, 85-91.

Wang, R., 1998. Resurgence of carbon monoxide: an endogenous gaseous vasorelaxing factor. Can. J. Physiol. Pharmacol. 76, 1-15

Wang, R., Wang, Z.Z., Wu, L., 1997. Carbon monoxide-induced vasorelaxation and the underlying mechanisms. Br. J. Pharmacol. 121, 927-934

Wet, C.J. D., Affleck, D.G., Jacobson; E., Avidan, M.S., Tymkew, H., Hill, L.L., Zanaboni, P.B., Moazami, N., Smith, J.R., 2004. Inhaled prostacyclin is safe, effective, and affordable in patients with pulmonary hypertension, right heart dysfunction, and refractory hypoxemia after cardiothoracic surgery. Thorac. Cardiovasc. Surg. 127, 1058-1067.

Wright, J.L., Tai, H., Churg, A., 2006. Vasoactive mediators and pulmonary hypertension after cigarette smoke exposure in the guinea pig. J. Appl. Physiol. 100,672-678. 
Yamakami, T., Taguchi, O., Gabazza, E.C., Yoshida, M., Kobayashi, T., Kobayashi, H., Yasui, H., Ibata, H., Adachi, Y., 1997. Arterial endothelin-1 levels in pulmonary emphysema and interstitial lung disease: relationship with pulmonary hypertension with exercise. Eur. Respir. J. 10, 2055-2060. 


\section{Appendix B}

\section{Research cigarette specification}

\section{Introduction}

During the late 1060's when increased emphasis was being placed on smoking and health research, it was determined that a cigarette that could be used as a research standard should be developed. In 1968, the Scientific Advisory Board of the Council of Tobacco Research requested the Industry Technical Committee to oversee the production of such a cigarette. The University of Kentucky's Tobacco and Health Research Program provided the organizational structure for developing such a cigarette. This reference cigarette served as an international standard for research purposes. The reference cigarette is useful for scientists involved in many aspects of research, and it provides a basis for comparing data that have been collected in different laboratories. The Kentucky Tobacco Research and Development Center produces different reference cigarettes (e.g., 1R3F, 2R4F, 1R5F etc) that vary in nicotine level and other ingredients. We used 1R3F research cigarette that contains the highest nicotine level. 


\section{Composition of the $1 \mathrm{R} 3 \mathrm{~F}$ research cigarette:}

1R3F-the Kentucky Tobacco Research \& Development Center equivalent to the experimental blend specified and used by the National Cancer Institute as their standard for experimental work. The reconstituted tobacco sheet portion of this blend was manufactured using the Schweitzer Process.

\begin{tabular}{lc}
\hline Flue-cured & $* 32.54 \%$ \\
Burley & $20.04 \%$ \\
Turkish & $11.09 \%$ \\
Maryland & $1.06 \%$ \\
Reconstituted Sheet & $27.17 \%$ \\
Invert Sugar & $5.30 \%$ \\
Glycerine & $2.80 \%$ \\
\hline * Wet weight basis &
\end{tabular}

Smoke analyses by FTC method

\begin{tabular}{|l|l|l|l|l|l|l|l|}
\hline Cigarette & $\begin{array}{l}\text { TPM } \\
\mathrm{mg} / \mathrm{cig}\end{array}$ & $\begin{array}{l}\text { FTC Tar } \\
\mathrm{mg} / \mathrm{cig}\end{array}$ & $\begin{array}{l}\text { Nicotine } \\
\mathrm{mg} / \mathrm{cig}\end{array}$ & $\begin{array}{l}\text { Water } \\
\mathrm{mg} / \mathrm{cig}\end{array}$ & $\begin{array}{l}\text { Puff } \\
\text { count/cig }\end{array}$ & $\begin{array}{l}\text { CO } \\
\mathrm{mg} / \mathrm{cig}\end{array}$ & $\begin{array}{l}\text { NOX } \\
\mathrm{mg} / \mathrm{cig}\end{array}$ \\
\hline 1R3F & 18.10 & 15.0 & 1.16 & 1.88 & 8.60 & 17.20 & 0.27 \\
\hline $1 \mathrm{R} 5 \mathrm{~F}$ & 2.08 & 1.67 & 0.16 & 0.30 & 7.18 & 2.95 & 0.11 \\
\hline 2R4F & 11.70 & 9.70 & 0.85 & 1.12 & 9.20 & 13.00 & 0.22 \\
\hline
\end{tabular}

TPM=Total Particulate Matter, FTC $=$ Federal Trade Commission, $\mathrm{Cig}=$ cigarette, $\mathrm{CO}=$ Carbon Monoxide, NOX $=$ Nitrogen Oxide. 


\section{Appendix C}

\section{Details of methodology for ET-1 measurement}

Measurement of endothelin in EDTA-plasma samples after precipitation:

Freshly collected EDTA-plasma sample from smoker and nonsmoker rats was put on ice immediately and centrifuged within one hour. Samples were stored at $-80^{\circ} \mathrm{C}$ until the assay was done. As lipemic and hemolytic plasma samples may give erroneous results, these kinds of samples were not assayed. Samples were mixed well before assaying. Duplicates for all values were used.

\section{Step1: Precipitation of plasma samples}

1. To pipette $1 \mathrm{ml}$ sample in a polypropylene tube.

2. To add $1.5 \mathrm{ml}$ of diluted PAA (Precipitating Agent Additive). Mixed well on a vortex mixer.

3. To cool sample to $4^{\circ} \mathrm{C}$ and to centrifuged for $20 \mathrm{~min}$ at $3000 \mathrm{X} \mathrm{g}$ at $4^{\circ} \mathrm{C}$.

4. To transfer supernatant into another polypropylene tube.

5. To dry all supernatants of the samples in a stream of nitrogen overnight. 


\section{Step 2: Performance of the assay}

1. Dried samples were re-dissolved in $500 \mu \mathrm{l}$ of assay buffer, mixed well and spin down insoluble substances.

2. Using the diluted endothelin stock were prepared serial dilutions with the PBbuffer down to approximately $0.6 \mathrm{fmol} / \mathrm{ml}$. PB-buffer was used as a zero standard.

3. Proceeded with assay protocol.

\section{Assay Protocol:}

1. All reagents and samples were equilibrated at room temperature $\left(18-26^{\circ} \mathrm{C}\right)$ before use in the assay.

2. Positions were marked for BLANK/STD (Standards)/SAMPLE/CTRL (Control) on the supplied protocol sheet.

3. Microtiter strips were taken out of the alubag, taking a minimum of one well as Blank.

4. Added a $50 \mu \mathrm{l}$ STD/SAMPLE/CTRL (Standard, white cap/Sample/Control, yellow cap) in duplicate into respective well, except blank.

5. Added a $200 \mu \mathrm{l}$ AB (Detection antibody, green cap) into each well, except blank, swirl gently.

6. Covered tightly and incubate at room temperature $\left(18-26^{\circ} \mathrm{C}\right)$ overnight $(16-24$ hours). 
7. Aspirated and washed wells $5 \mathrm{x}$ with $300 \mu \mathrm{l}$ diluted WASHBUF (Wash buffer), removed remaining WASHBUF by hitting plate against paper towel after the latest wash.

8. Added a $200 \mu \mathrm{l} \mathrm{CONJ} \mathrm{(Conjugate)} \mathrm{into} \mathrm{each} \mathrm{well.}$

9. Covered tightly and incubate 1 hour at room temperature.

10. Aspirated and washed wells $5 \mathrm{x}$ with $300 \mu \mathrm{l}$ diluted WASHBUF (Wash buffer), removed remaining WASHBUF by hitting plate against paper towel after the last wash.

11. Added a $200 \mu \mathrm{l}$ SUB (Substrate) into each well.

12. Incubated for 30 minutes at room temperature $\left(18-26^{\circ} \mathrm{C}\right)$ in the dark.

13. Added a $50 \mu 1$ STOP (Stop solution) into each well, shaken well.

14. Measured absorbance immediately at $450 \mathrm{~nm}$.

\section{Calculations of results:}

The blank extinction was subtracted from all other values. The Standard curve was constructed from the Standard values using MS Excel program. Respective dilution factors were taken into consideration. 
Plasma levels ( $\mathrm{fmol} / \mathrm{ml})$ of endothelin-1 (ET-1) in control and smoking rats:

\begin{tabular}{|l|l|}
\hline Control $(\mathrm{n}=10)$ & Smoking $(\mathrm{n}=10)$ \\
\hline 1.20542441 & 6.061024611 \\
2.258915118 & 5.369161226 \\
1.253139126 & 6.207935711 \\
1.307132094 & 5.592667002 \\
2.165996986 & 6.003264691 \\
1.467855349 & 4.791562029 \\
1.648669011 & 5.8814666 \\
1.255650427 & 5.306378704 \\
1.624811652 & 5.932948267 \\
1.600000000 & 5.344048217 \\
\hline
\end{tabular}

Graph Pad Prism was used to analyze the data. 


\section{Appendix D}

Micro vessel study by pressure myograph
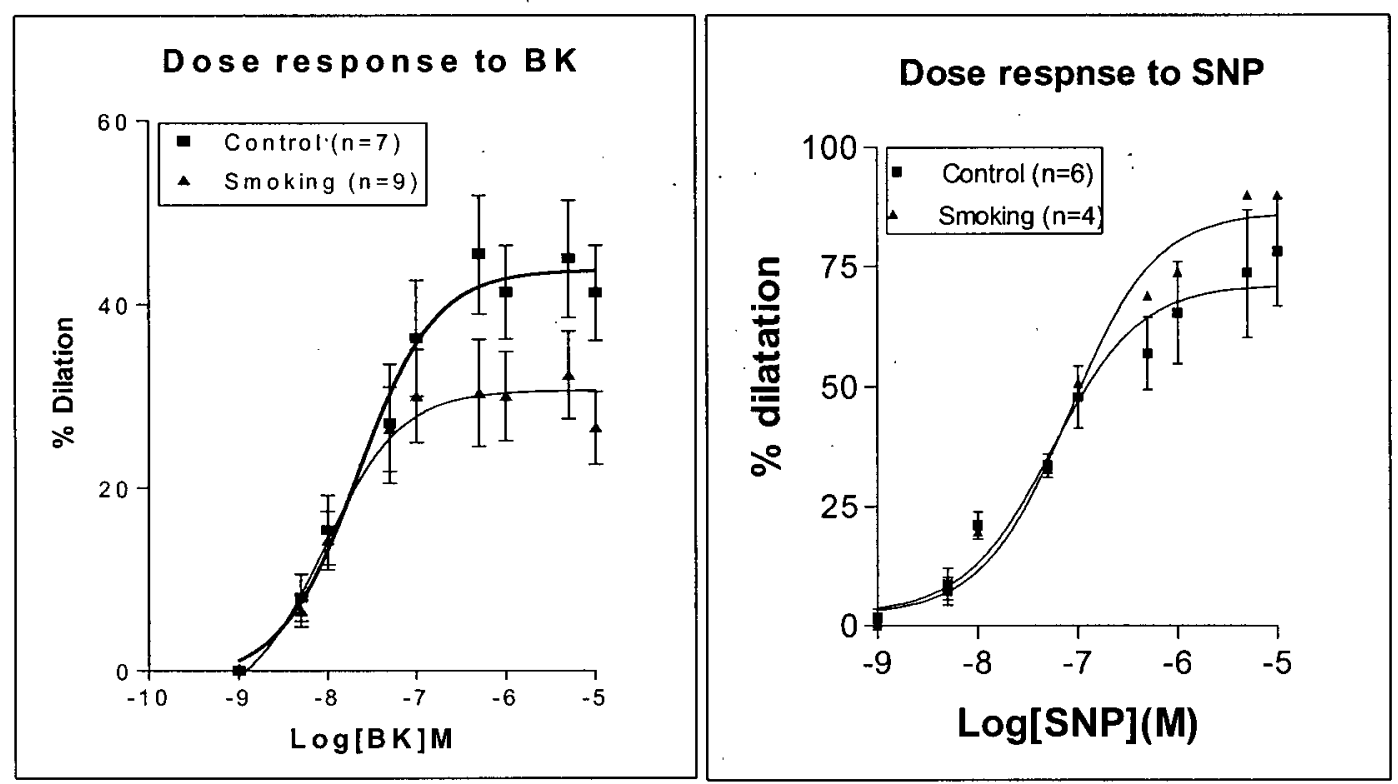

Figure 4. 1 Lack of difference both in endothelium-dependent (Bradykinin=BK) and independent (Sodium Nitro Prusside=SNP) vasodilatation between control and smoking rat middle cerebral artery (MCA).

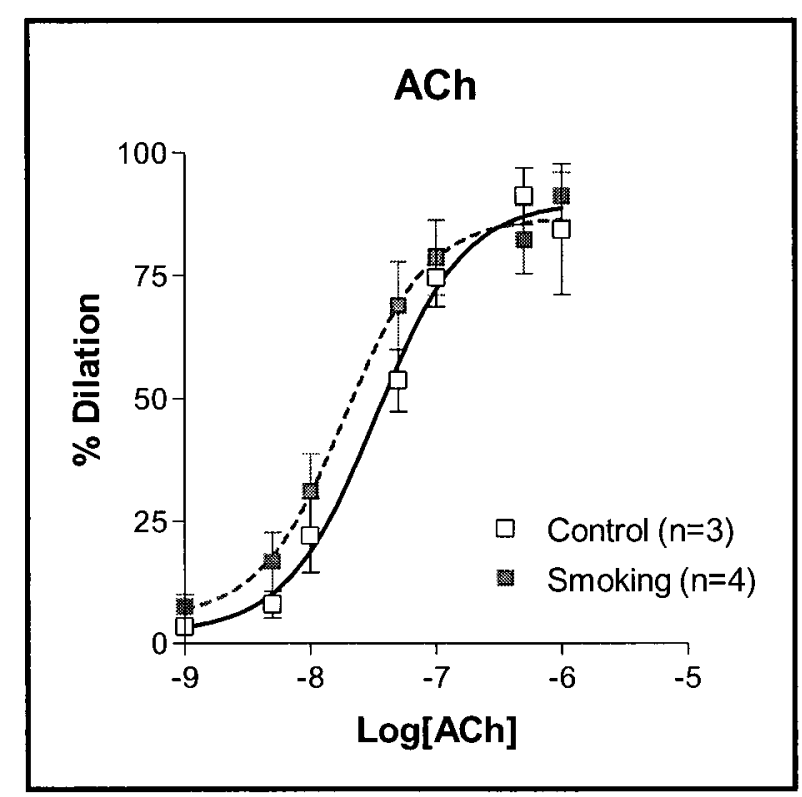

Figure 4. 2 Lack of difference in endothelium-dependent (ACh) vasodilatation between control and smoking rat septal coronary artery. 